\title{
THE STATE OF MONTANA'S RESPONSES T' PUBLIC COMMENTS ON THE UCERB RESTORATION PLAN PROCEDURES AND CRITERIA
}

PREPARED BY:

STATE OF MONTANA

NATURAL RESOURCE DAMAGE PROGRAM

FEBRUARY 15, 2000

STATE DOCUMENTS COLLECTION

HEB 122001

MONTANA STATE LIBRARY.

1515 E. 6th AVE.

HELENA, MONTANA 59620

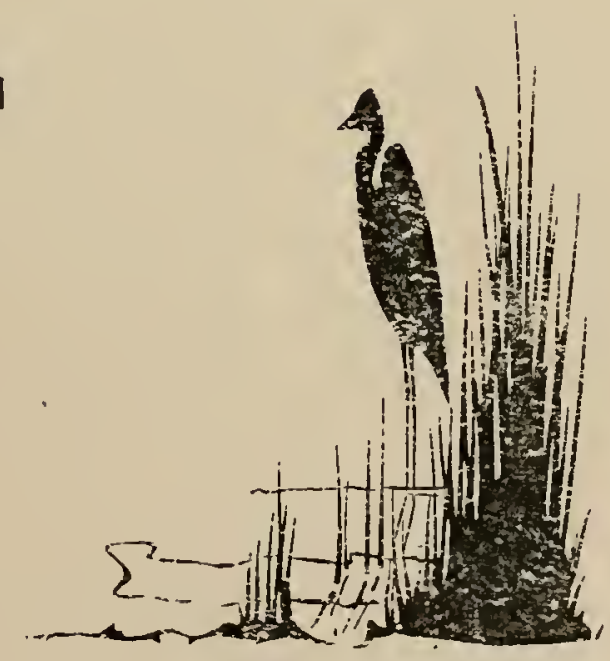




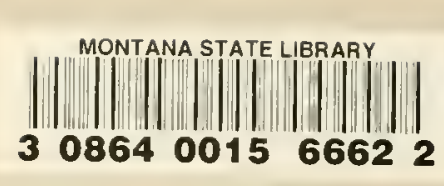




\section{The State of Montana's Responses To Public Comments ON The UCFRB RESTORATION PLAN PROCEDURES AND CRITERIA}

\section{PREPARED BY:}

State of Montana Natural Resource Damage Prograi

FEBRUARY 15, 2000

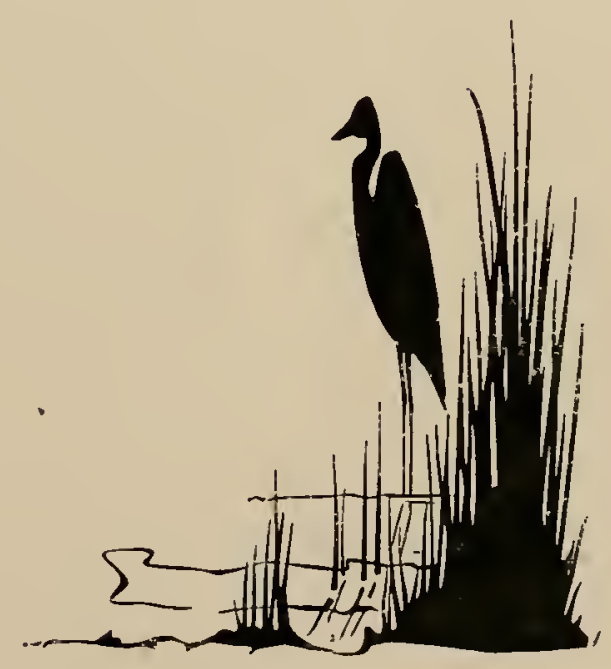




\section{Digitized by the Internet Archive in 2011 with funding from Montana State Library}




\section{INDEX \\ State's Response to Comments}

Comment Category

$\underline{\text { Page }}$

Category 1: Satisfaction with the Plan

Letters 1A, B, S; 3D; 6A; 7A, B, C, D; 8A; 9A, B; 11A, B, C, E; 13B, E;

$15 \mathrm{~A}, \mathrm{~F} ; 18 \mathrm{~A} ; 19 \mathrm{~A} ; 21 \mathrm{~A} ; 31 \mathrm{~A}$.

Category 2: Project Location

Letters 4B; 6H; 7I; 9E; 10B; 12H; 13A; 15B;16E; 17B; 18B; 19B, CC, II, JJ; 20B, E; 21B; 22B, D; 23B; 24A; 26A; 27B; 28B; 35B, C, H; 36B, D.

Category 3A: Merger of Trustee and Advisory Councils

Letters 5B; 6C, E; 7H; 8G; 9D; 13D; 14A; 15D, E; 16B; 17C; 18D; 19C, M, T; 20D; 21F; 22E; 23E; 24C; 25B; 27G; 28A; 35F, G.

Category 3B: Advisory Council's Input

Letters 6B, D; 7G; 9D; 12C, F; 19Y.

Category 4: Specific Projects or Types of Projects

Letters 4G, H; 5I; 7J; 9B; 10A; 11B, G; 12A, B; 19E, G, H, DD, EE; 22E; 29C, I; 30B; 31A; 34J; 36C.

Category 5: Chapter 3 Planning Procedures

Letters $11 \mathrm{H} ; 13 \mathrm{C} ; 14 \mathrm{~B}, \mathrm{C} ; 15 \mathrm{~F} ; 16 \mathrm{~A}, \mathrm{D} ; 19 \mathrm{P}, \mathrm{R}, \mathrm{V}, \mathrm{W} ; 29 \mathrm{~F}$.

Category 6: Need for Specific Goals and a Comprehensive Plan

Letters 3A, B; 4A; 5A; 7E, F; 8B; 9C; 10C, E; 11D, E, F; 16C; 19F, S; 29E;

$31 \mathrm{~B}, \mathrm{C}, \mathrm{D}, \mathrm{E}$.

Category 7A: Structure of NRDP

Letters 7B; 12D; 15C; 17A; 18C; 19D, N; 20C; 21 G; 22G; 23C; 25C; 26C;

$27 \mathrm{~F}, \mathrm{H} ; 35 \mathrm{E}$.

Category 7B: Location of NRDP Office

Letters 19D, N; 20C; 22G; 23D; 24B; 25C; 26B; 27G; 30A.

Category 8: Participation of Tribes and DOI in Planning Process

Letters 2B, C, D, E, F; 3E, F, G, H, I; 19BB.

Category 9: Monitoring and Research

Letters 5G; 10F; 11E; 7K; 8E; 12L; 14D; 15G; 19GG, KK; 31B. 

Category 10: Consultation with EPA and Coordination with Remediation

Letters 1D, L, M, N, O, Q, R, S, 11C; 19F; $21 \mathrm{C}$.

Category 11: Injury Description.

Letters $1 \mathrm{E}, \mathrm{F}, \mathrm{G}, \mathrm{H}, \mathrm{I}, \mathrm{J}, \mathrm{K} ; 13 \mathrm{~B} ; 19 \mathrm{~F}, \mathrm{~J}, \mathrm{~K}, \mathrm{~L}$.

Category 12: Stage 1 and Stage 2 Criteria for Decision Making. Letters 7D; 9A; 10G; 12I, J, K; 29H; 34K.

Category 13: Public Participation

Letters 6E; 7C; 8F; 12G, E; 29D; 34D.

Category 14: Emphasis on Clark Fork River

Letter 35D.

Category 15: Public Access 1ssues

Letters 4E; 5D; 6G; 8C; 19FF.

Category 16: Restoration Fund Management

Letter 27E, D.

Category 17: Project Implementation

Letters 4D; 19U; 34A, E, L.

Category 18: Application Form Letters 5J; 6F; 190; 34B.

Category 19: Projects in Areas Where No ROD Has Been Issued Letters $4 \mathrm{C}$; 9F; $27 \mathrm{C}$.

Category 20: Administrative Expenses

Letters $5 \mathrm{G} ; 19 \mathrm{HH}, \mathrm{LL} ; 22 \mathrm{~F}$.

Category 21: Upfront Funding

Letters 5F; 8D; $19 \mathrm{X}$.

Category 22: Project Development Grants

Letters $5 \mathrm{H} ; 19 \mathrm{Q} ; 34 \mathrm{C}$.

Category 23: Chapter 4 Terminology

Letters 19Z, AA; $29 \mathrm{G}$.

Category 24: SSTOU Remediation.

Letters 21D, E; 29B. 

Category 25: Normal Government Function

Letters 7L; 12L.

Category 26: Multiple Year Grants Letter 34F, G.

Category 27: Opposition to the Plan Letters 35A; 36A.

Category 28: MEPA Compliance . Letter 34I.

Category 29: Montana v. ARCO Settlement Letter 29A.

Appendix : Public Comment Letters 

On September 10, 1999 the State of Montana released for public comment its draft Upper Clark Fork River Restoration Plan Procedures and Criteria. The release of this "Plan" for public comment was advertised in several newspapers in the Upper Clark Fork River Basin ("UCFRB") and the Plan was sent to various libraries in the UCFRB, Missoula, Great Falls and Helena, so that it would be available for public review. In addition, the State sent copies of the Plan to more than 100 individuals who, in the past, have demonstrated a special interest in this matter. Those individuals included members of the UCFRB Remediation and Restoration Education Advisory Council, the UCFRB Steering Committee, various conservation district managers, environmental groups, and local governmental entities in the Basin.

The public comment period on the Plan closed on October 15, 1999, and by that date the State had received 36 comment letters from various persons and entities (there were 4 persons or entities who sent 2 comment letters each). ${ }^{1}$ Copies of the public comments received are in the appendix hereto. (It should be noted that each of the comment letters has been numbered and each comment has been assigned an alphabetic designation so that readers of this document can readily refer to the precise text of the various comments to which the State is responding.) The State's responses to these comments are set forth below. These responses were prepared by the States Natural Resource Damage ("NRD") Program on behalf of the Trustee, i.e., the Governor, and the Governor's NRD Policy Committee.

CATEGORY 1: Satisfaction with the Plan. The State received 25 comments from 14 persons or entities variously expressing congratulations on the settlement, satisfaction with various aspects of the proposed restoration plan, and appreciation for noticeable improvements in this draft of the Plan. (See Letters 1A, B, S; 3D; 6A; 7A, B, C, D; 8A; 9A, B; 11A, B, C, E; 13B, E; 15A, F; 18A; 19A; 21A; 31A.)

RESPONSE: The State of Montana greatly appreciates these comments and other words of encouragement. The State is thankful that a number of the commentors are satisfied with various aspects of the Plan, including the improvements over previous drafts. The State notes that a number of these improvements were made based upon previous informal comments from members of the public and believes that the changes which it will make in the current draft, as the result of public comment, will further improve the Plan.

\footnotetext{
'There were two comment letters received after the deadline for comments. Those letters, copies of which are included at the end of the appendix, were not responded to directly although the State's responses, herein, respond indirectly to these letters. It should also be noted that before the release of the September 10, 1999 draft Plan, the State had provided prior working drafts of the Plan to the Advisory Council and certain other members of the public at their request; thus, the September 10,1999 draft already reflected some public input.
} 
CATEGORY 2: Project Location. The State received 30 comments from 20 persons or entities stating, variously, that the proceeds of the NRD settlement should be spent only on restoration projects located within the UCFRB, that all NRD money should be spent for projects in the UCFRB "damage corridor," or that if NRD money is not spent in the Basin, it should have a direct benefit in the Basin. (See Letters 4B; 6H; 7I; 9E; 10B; 12H; 13A; 15B; 16E; 17B; 18B; 19B, CC, II, JJ; 20B, E; 21B; 22B, D; 23B; 24A; 26A; $27 \mathrm{~B} ; 28 \mathrm{~B} ; 35 \mathrm{~B}, \mathrm{C}, \mathrm{H} ; 36 \mathrm{~B}, \mathrm{D}$.) Some of these comments set forth more specific recommendations in this regard:

COMMENT: Trout Unlimited ("TU") proposes that projects inside the hydrological bounds of the UCFRB should get priority, projects outside the "damage corridor" but in the UCFRB should also be eligible for funding if they directly benefit or replace resource inside the damage corridor, other projects outside the corridor but in the UCFRB should be eligible if there is a clear demonstration that they are necessary and appropriate replacement for injured resources that cannot be restored, and projects outside the hydrologic bounds of the UCFRB should be ineligible unless it can be conclusively demonstrated they benefit resources inside the UCFRB. (Letter 7I.)

COMMENT: The Clark Fork Coalition ("CFC") recommends that language on page 38 discussing project location be strengthened to include "the only exception to this criteria will be that if projects extend outside the hydrologic boundary of the UCFRB, then they must demonstrate a direct benefit to injured resources and/or lost services in the UCFRB." (Letter 9E.)

COMMENT: Powell County comments that the "Project Location" criterion be taken out of the Stage 2 Criteria and made an initial screen. (Letter 12H.)

COMMENT: Butte-Silver Bow County ("BSB") and Butte Local Development Corporation ("BLDC") suggest that the "Project Location" criterion description language be tightened up to ensure all projects are located within the UCFRB. BSB states that "there is more work than there is money to get it done, thus, it seems rather inconsistent to reserve the authority to spend money on projects outside the Basin." (Letter 19.)

COMMENT: The Greenway Service District ("GSD") comments, regarding the geographic location of projects, that the State should factor in which claims were released in the settlement of the law suit in determining which restoration projects will be funded. (Letter 21B.)

RESPONSE TO CATEGORY 2 COMMENTS: After careful consideration, the State of Montana has decided that the Plan should be modified to require, with one limited exception, all projects designed to restore or replace injured resources or impaired services be located in the UCFRB. Under that exception a project to restore native trout in the Big Blackfoot River drainage will be considered for funding provided there is a 
showing that the project is intended to restore native trout that have been injured in the UCFRB and that it would be impractical or uneconomic to do so in the UCFRB. The "Project Location" criterion set forth in the Plan will be modified to reflect this decision. While the State believes it would be legally acceptable, under appropriate circumstances, to fund projects located outside the hydrologic boundary of the UCFRB, the State agrees with the point made by several commentors, including Butte/Silver Bow County, that "there is more restoration work to be done than there is money to get it done." Therefore, the State agrees that it makes sense to require, with that limited exception, restoration and replacement projects be located in the Basin. The State does note that the Trustee has the authority to revisit this decision in the future.

The State believes that the limited exception is justified because it may be impractical or very expensive to restore native trout in the UCFRB and because of the importance of such trout to the eco-system and under the Endangered Species Act. Also, because of its connection to the Upper Clark Fork River, restoration of native trout in the Big Blackfoot may help to restore native trout in the Clark Fork.

Responding to Powell County's comment that the "Project Location" criterion should be taken out of the Stage Two Criteria and made solely part of the initial screening, the State will revise the list of initial screening items and add, "project location in the UCFRB" as a "Minimum Qualification." The State, however, does not agree that the "Project Location" criterion should be taken out of Chapter 4. That is because the precise location of any proposed project will remain an important consideration notwithstanding the requirement that the project be located in the UCFRB. As Trout Unlimited recognizes, projects within the UCFRB but outside the "damage corridor" may not receive priority as high as projects within the "damage" or "injury corridor," but will be eligible for funding if they directly benefit or replace injured resources within the "injury corridor."

Responding to the GSD's comment about factoring in the claims that were released in the settlement, the State notes that it is doing so, in essence, by requiring that projects be located in the Basin and restore or replace injured resources or services which were the subject of the lawsuit. GSD's comment implies that because the State's restoration claims for three sites were not resolved by the settlement, projects to restore natural resources at those sites should receive lower priority than projects at the six restoration sites which were settled. There is some logic to this proposition. In fact, as is reflected in the Stage 2 criterion, "Results of Response Actions," the State does not intend to approve projects which would duplicate or in any way interfere with the proposed restoration actions which remain the subject of Montana v. ARCO. This logic, however, does not completely follow when one also considers that the compensable damages claims for these three restoration sites were settled, and that the restoration damage claims at three of the six other sites were claims for very small amounts of damages based upon "natural recovery." 
CATEGORY 3A: Merger of Trustee and Advisory Councils. The State received 24 comments from 18 persons or entities stating that the UCFRB Remediation and Restoration Education Advisory Council should assume the duties of the Trustee Restoration Council by combining, merging, or otherwise reconstituting these bodies as one decision-making authority to streamline the decision-making process and ensure that restoration planning authority rests in a group that includes representatives of basin local governments and interests. (See Letters 5B; 6C, E; 7H; 8G; 9D; 13D; 14A; 15D, E; 16B; 17C; 18D; 19C, M, T; 20D; 21F; 22E; 23E; 24C; 25B; 27G; 28A; 35F, G.) Some of these commentors made specific suggestions as to additional representatives that should be included on a combined Advisory/Trustee Council. One commentor suggested that the Directors of the State Departments of Agriculture, Transportation, and Commerce should be added, and others suggested adding the Governor's Chief of Staff and the Director of DNRC. Still a few others suggested that the combined Council should include the heads of local governments in the Basin. One person suggested that a single council be formed such that the input of the Trustee Council, the Advisory Council, the Tribes and DOI would form a "cohesive voice in advising the Governor." Another commentor suggested that the organizational structure of the decision making process raises conflict and may place the Governor in a decision-making mode, which is nonproductive and potentially divisive causing real gridlock and lost opportunities to restore the region.

RESPONSE: The State of Montana has carefully considered all of these comments to the effect that the Trustee Restoration Council should be combined with the Advisory Council to form one decision making authority. The State still believes that by keeping these bodies separate, the State can proceed with a restoration decision making process which is the most efficient under the circumstances, and which will operate in the best interests of the people of the State as a whole, and the residents of the UCFRB, in particular. Having said that, however, to assure that the Advisory Council has an effective voice which will be considered by the Trustee Council and the Governor, the State will modify the Plan and provide that the Chairman of the Advisory Council will be a voting member of the Trustee Council.

The State's decision in this regard is based upon a number of considerations. First, CERCLA provides that it is the duty of the Governor, acting as "Trustee" of the Restoration Fund and the injured natural resources, to prepare and adopt restoration plans. (See 42 USC $§ 6911$ (I).) It should be understood that the Governor acts through his or her staff and other representatives, including the Natural Resource Damage Program (NRDP) and cabinet members who form the Trustee Restoration Council. If the Trustee Council were merged with the Advisory Council and the NRDP reported to that combined council, it could be argued that preparation of the annual restorations plans and the principal decision making authorities who approve those plans are not under the control of the Trustee. 
Second, it could be argued that delegation, in essence, of decision making authority to a combined Advisory/Trustee Council would violate another provision of CERCLA which expressly provides that the Governor of a state may delegate trustee authority to "state officials." (42 USC $\S 9607(f)(2)(B)$.

Third, the delegation of this authority to a combined Advisory/Trustee Council could arguably violate the Memorandum of Agreement ("MOA") among the State of Montana, the Confederated Salish and Kootenai Tribes, and the United States Department of Interior, which was agreed to by the State as part of the settlement. The MOA provides the Tribes and DOI with certain specific consultation rights as to the "State of Montana's" restoration plans. It is possible that the Tribes and DOI could argue that the State was not living up to these covenants if control of the restoration planning process is, in essence, given over to a council which is not controlled by the State.

Fourth, the settlement money is held in trust for the people of the entire State of Montana, yet the Advisory Council is limited to residents of the UCFRB and Missoula, and certain government representatives. Since the Basin residents would be in the majority on a combined Advisory/Trustee Council, it may be argued that such a council would not be representative of the State as a whole.

In addition, the State's involvement in the UCFRB restoration process will not only include the preparation and approval of annual Restoration Work Plans, it will also involve, among other things, project implementation, oversight, paying contractors, accounting for all expenditures, project follow-up, and monitoring. It is currently contemplated that the Trustee Restoration Council will also be responsible for overseeing the NRDP's performance of these other duties. The sheer number of people who would sit on a combined Advisory/Trustee Council would make the performance of this oversight both inefficient and cumbersome. It has been suggested by some that a combined Advisory/Trustee Council would only deal with restoration planning decisions, while the Trustee Council would remain responsible for overseeing all of the State's other restoration responsibilities. While this is another possible arrangement, there is a reasonable argument that the same group should be responsible for, and thus accountable for, the entire process. Presumably the Trustee Restoration Council will gain insight as to which projects should be approved based upon its experience in the implementation and oversight of similar projects which it previously approved.

Finally, by merging the functions of the two councils, the State would lose the benefits it originally contemplated when it established the Advisory Council. What would be lost would be the separate and independent advice of the Advisory Council which the State hoped to weigh, in making restoration planning decisions, independent of 
the technical opinions of the State staff and policy opinions of the State agency directors. ${ }^{2}$ The "separate Advisory Council/ separate Trustee Council" model which the Plan adopts is very similar to the model utilized by the State of Alaska in the Exxon/Valdez NRD Restoration Program. In that situation, the Trustee Council greatly values the input of the "Public Advisory Group" and the process has worked smoothly, as the State of Montana believes it will in this instance.

A number of the commentors are concerned that the State will ignore the advice of the Advisory Council if the two councils are not combined. This will not be the case. As the Plan indicates, and as will be further clarified by additions to the Plan, the advice of the Advisory Council will be sought by the NRD Program and the Trustee Council at all decision making stages. If there is a disagreement between the Advisory Council and the Program or the Trustee Council, that disagreement will be considered by the Governor before final decisions are made. Furthermore, as a full voting member of the Trustee Council, the Chairman of the Advisory Council can see to it that the State appropriately considers the Advisory Council's recommendations.

\section{The point that some commentors made that there should be only one} comprehensive recommendation transmitted to the Governor, rather than one from the Trustee Council, one from the Advisory Council, and possibly separate recommendations from the Tribes and DOI, has some merit. However, it may not be realistic to believe that agreement on one recommendation will always be reached given the diversity of interests and limited time available to make decisions. The Tribes and DOI have an independent right under the MOA to provide separate and distinct recommendations. Moreover, the State does not believe that the benefits of obtaining one recommendation outweigh the reasons for not combining the two councils as stated above. In the event that the Trustee is given two or more recommendations, the Trustee can competently weigh those recommendations and come up with an appropriate decision.

CATEGORY 3B: Advisory Council's Input. The State received 7 comments from 5 persons or entities regarding the Advisory Council's input in the restoration project selection process. These comments are as follows.

COMMENT: The Advisory Council comments that if the NRD Program is going to make recommendations to the Trustee Council on whether they should fund development of a project, that decision should involve some participation with the Advisory Council. The council should be able to look at these proposals for projects' development costs as well as the specific projects themselves. (See Letter 6B.)

\footnotetext{
${ }^{2}$ Some commentors argue that the Advisory Council is not independent of the State because certain State officials are on the Council. The Governor addressed this issue in an amendment to his original executive order establishing the Advisory Council. In that amendment (Executive Order 14-99, Sept. 14, 1999), the Governor provides that State officials on the Council shall be "non-voting members."
} 
RESPONSE: The Advisory Council may review applications for project development grants, consult with the State, and make recommendations to the NRDP and Trustee Council on all project development funding proposals. The text of the Plan will be revised to clarify this.

COMMENT: The Advisory Council comments that the role of the Advisory Council is inaccurately portrayed in the draft Plan as a group that advises the NRD Program, when, in fact, the Council's role is to advise the Governor. (See Letter 6D.)

RESPONSE: In the Plan, the State set forth a procedure by which the Advisory Council can perform its responsibilities of advising the Governor and promoting public understanding of the restoration and remediation process, as set forth in the executive order creating this body. In Figure 2, the Annual Restoration Planning Cycle, the July box includes the word "advise." This reference was intended to describe the process by which Advisory Council's input to the NRDP, which acts as the Governor's staff on this matter, will be an important aspect of the early development of the restoration work plan. The flowchart is not intended to limit the Advisory Council's role of advising the Trustee Council and the Governor and, in fact, reflects this role.

COMMENT: TU comments that the plan should make recommendations on how to refine the Advisory Council and suggests that each committee member should have technical or policy background on the types of resources that need restoration, that there should be no elected officials on the committee (local government could be represented by local health officials), agencies that might be eligible for funding should not have regular, voting members on the committee (ex officio members instead), and that the committee should have at least one member who has a demonstrated familiarity with the claim, settlement language, and the DOI rules and regulations. The purpose of these recommendations are to ensure that projects are screened objectively and that the review process is kept somewhat insulated from political, pork-barrel and bureaucratic agendas. The committee should have bylaws that include a strong conflict of interest policy, especially in regard to committee members who are consultants, and that committee members should be paid for travel, phone and meals. (See Letter 7G.)

RESPONSE: The State recognizes that TU's comments on refining the Advisory Council were made in the context of TU's additional comment that the Advisory Council should be reconstituted to perform the duties of the Trustee Council, as that body is described in the Plan. The UCFRB Remediation and Restoration Education Advisory Council was created by executive order of the Governor, and it is beyond the scope of the Plan to set forth a recommendation on restructuring the Advisory Council. As stated in a previous response, the State disagrees that the Advisory Council and Trustee Council should be merged. The Advisory Council was created with specific directions to educate the public and advise the Trustee. The Advisory Council was constituted to accomplish this unique purpose of providing input from a council of community leaders and citizens 
of the UCFRB, and is considered by the State to be a vital part of the restoration decisionmaking process.

COMMENT: The CFC comments that a shortcoming of the Plan is that it does not contain specific language that ensures the Advisory Council will be able to weigh in after the public comment period is closed, or that the council will make formal recommendations to the Trustee Restoration Council and/or the Governor. The CFC comments that the plan should be changed to clarify exactly when the Advisory Council makes formal recommendations, and to whom they make them. The CFC recommends adding an additional bullet to page 31 (between bullets 6 and 7) which states that "after the NRD Program incorporates public comment into the final Restoration Work Plan, the UCFRB Advisory Council shall make formal recommendations on project funding to the Trustee Restoration Council and the Governor." (See Letter 9D.)

RESPONSE: Public comment received on the draft Restoration Work Plan, the NRDP's responses to public comment, and the proposed final Restoration Work Plan will be available to the Advisory Council prior to the Trustee Council's final decision. As set forth in Figure 2, the Advisory Council may submit its recommendations to the Trustee Council after reviewing these documents. The State will add a statement on page 31 of the Plan clarifying the Advisory Council's role in this regard.

COMMENT: Powell County comments that on page 26, it is difficult to understand whether the Advisory Council has any significant role in the entire process, and that elimination of a local basin wide representation during the project phase seems foolhardy; some role for the Advisory Council needs to be devised. (See Letter 12C.)

RESPONSE: The Advisory Council was created by executive order to "promote public understanding of the State's efforts to remediate and restore sites in the UCFRB that have been injured by hazardous substances for which ARCO is liable." To effectuate its mission, the Council may provide "advice ... to the Governor with respect to issues involving remediation and restoration efforts in the UCFRB." The Plan sets forth a procedure by which the Advisory Council may fulfill this mission during the project selection process (see pp. 30-31, Fig. 2). The State therefore disagrees with Powell County that the Advisory Council has no significant role in the Plan. To the contrary, the procedure as outlined in the Plan provides a mechanism by which a body representing local interests may directly advise the NRDP, the Trustee Council, and the Governor on project funding proposals at various stages throughout the restoration decision-making process.

COMMENT: Powell County comments, relative to page 32, that the word "may" regarding the Advisory Council's role in reviewing applications, creates a question of whether the Advisory Council has a significant role in funding decisions. (See Letter 12F.) 
RESPONSE: Powell County probably refers to the word "may" as it appears in Figure 2, i.e., that the "Advisory Council . . may review applications ...." The State disagrees that the use of the word "may" creates a question whether the Advisory Council has a significant role in funding decisions. The word "may" was utilized to express an option that the Advisory Council may exercise. The State does not intend to dictate the actions of the Advisory Council as it fulfills its responsibilities under the executive order.

COMMENT: BSB comments on Chapter 4, Criteria of Decision Making, that if the State prefers the non-quantitative approach to evaluating projects, the role of the Advisory Council should be elevated to ensure meaningful involvement in the project evaluation process. (See Letter 19Y.)

RESPONSE: BSB is correct that the State prefers the non-quantitative approach to evaluating projects and disagrees with the implication that the procedure as currently set forth in the Plan does not ensure meaningful involvement in the project evaluation process for the Advisory Council. See the Responses to Powell County's comments above for discussion of the role of the Advisory Council.

\section{CATEGORY 4: Specific Projects or Types of Projects. The State received 24} comments from 14 persons or entities regarding different projects that should be funded or types of projects to fund. Because most of these comments tended to address specific projects or funding suggestions and differed one from another in content, they are listed individually and will be addressed as such.

COMMENT: The Montana Association of Conservation Districts ("MACD") comments that the restoration potential for injuries to individuals who have suffered economic harm should be addressed. (Letter 4F.) The UCFRB Steering Committee similarly comments that the Plan does not address loss of agricultural productivity and that such productivity should be a benefit pursued by a restoration road map. (Letter 5C.)

RESPONSE: The State of Montana understands that private individuals, including farmers, ranchers, and businesses, have suffered economic harm as a result of injuries to the State's natural resources. CERCLA, however, does not provide for the recovery of damages sustained by private individuals or entities, including losses of agricultural productivity. Accordingly, the State, in Montana v. ARCO, made no claim for such losses. Furthermore, the law and the Consent Decrees do not allow the expenditure of the damages recovered in Montana v. ARCO for private purposes, including private agricultural purposes.

COMMENT: MACD comments that language on page 42 emphasizes the exclusion of humans and livestock as management techniques and suggests the following 
substitute paragraph: "The use of best management practices. Managing natural resources through the adoption and use of best management practices can create recovery of the resource while maximizing public benefits from it. Examples include comprehensive weed management practices, revegetative practices, hunting and fishing management approaches, irrigation water management techniques, grazing management systems, and management of livestock in riparian zones." (Letter 4G.)

RESPONSE: The State of Montana appreciates the other examples of management techniques which can produce tangible improvements in the condition injured natural resources. The State will incorporate most of these examples into the text at page 42. It should be understood, however, that the examples given on page 42 , and elsewhere in Chapter 5, are just potential examples of actions which could possibly be taken, if circumstances were appropriate, to help restore natural resources. By providing these examples the State is not necessarily endorsing such actions as they may apply to any particular situation. Having said that, the State continues to believe that the exclusion of humans and livestock as management techniques to help restore natural resources may be appropriate in certain circumstances.

COMMENT: The UCFRB Steering Committee comments that acquiring water rights on a voluntary basis should be considered a permissible restoration activity on page 39, and Margie C. Smith comments that acquiring the rights to any and all water available at this time should be first on the list of steps in restoration. (Letter 5I, 30B.)

RESPONSE: The State agrees with the commentors that acquiring water rights may be an appropriate restoration activity and will revise page 39 to clarify this.

COMMENT: TU comments that it disagrees with upgrading Butte's Big Hole water system with Restoration Funds, and comments that it should be considered a normal service of local government. TU further comments that there may be other water sources within the Clark Fork basin that could be tapped using NRD funds if the project proponent demonstrates that the venture will replace groundwater identified in the claim as damaged and which cannot be restored. (Letter $7 \mathrm{~J}$.)

RESPONSE: It is beyond the scope of this UCFRB Restoration Plan Procedures and Criteria to identify or comment on specific projects which may be proposed under this restoration program. Generally speaking, however, the State agrees that it may be appropriate to fund projects that replace groundwater resources which were claimed to be injured by the State in Montana v. ARCO.

COMMENT: The CFC and Missoula Water Quality Advisory Council ("MWQAC") comment that they support the position that proposed projects must restore, replace, or acquire the equivalent of injured natural resources, and that actual restoration of injured resources be given priority. (Letter 9B, 11B.) 
RESPONSE: The State agrees with this comment and the Plan reflects this position.

COMMENT: MWQAC believes that top priority should be given to projects with the greatest potential to restore the river's natural integrity, particularly its native fishery, and feels that removal or isolation of metals, especially at Milltown Dam, to prevent the further migration of metals downstream, is of critical importance. (Letter 11G.)

RESPONSE: MWQAC's comment regarding the priority to be given to restoring the river's natural integrity is noted. The State believes that the restoration of native species (bull and cutthroat trout) in the Clark Fork River may result from restoration projects aimed at restoring trout species generally.

As for Milltown, the State notes that its Restoration Determination Plan (Oct. $1995)$ selected the "no action" alternative for Milltown Reservoir. Nevertheless, restoration projects proposing to remove or isolate metals at Milltown Dam will be considered, provided that at the time such proposals are made the ROD for the Milltown site has been selected.

COMMENT: The Montana Environmental Information Center ("MEIC") comments that the full amount of the settlement, \$213 million, should be used for restoration projects rather than economic development because the settlement amount is less than that needed for river restoration. MEIC recommends that highest priority should be given to those projects with the most likely chance of restoring the river's biointegrity - particularly its native fishery. (Letter 10A.)

RESPONSE: The State of Montana agrees that the Restoration Fund, should be used for projects which restore or replace the injured resources and impaired services and that projects that promote economic development are inappropriate under the law unless such projects focus on the restoration or replacement of injured resources or impaired services. With respect to biointegrity and restoration of the native fishery, please see the immediate preceeding response.

COMMENT: Powell County comments that in light of the "planned Greenway for the upper portion of the river," additional words should be added on page 2 that more completely describe the recreational activities/opportunities along the Clark Fork River in the Anaconda area including fishing, water fowl hunting, bird watching, floating, etc. (Letter 12A.)

RESPONSE: Powell County's comment regarding a potential "Greenway" for the upper portion of the river is noted. The State will add language at page 2 to more completely describe the recreational activities along the Clark Fork River. 
COMMENT: Powell County comments that on page 4, injured resources are given undue weight as opposed to services, and comments that in reviewing Chapter 2, the word "services" is not discussed (and should be). (Letter 12B.)

RESPONSE: The focus of the State of Montana's lawsuit, Montana v. ARCO, has been the restoration of injured resources. On page 38 of the Plan, the State sets forth a criterion which reflects the State's policy entitled, "Actual Restoration of Injured Resources," which indicates that "the actual restoration of resources that were injured should be given priority." The State does recognize the appropriateness of restoring impaired services in addition to injured resources, and observes that the restoration of services can be accomplished by restoring resources. Furthermore, the Plan does discuss "impaired services" in Chapter 2 at pages 23 and 24. And services are discussed in a number of other passages throughout the Plan; Chapter 5, in particular, deals with the replacement of lost services.

COMMENT: BSB comments that there needs to be strict accountability for funds set aside for SSTOU cleanup, that the project should address both remediation and restoration where possible, and that there should be construction of a Greenway as the final land use. (Letter 19E.)

RESPONSE: The accountability of funds set aside for the Streamside Tailings Operable Unit ("SSTOU") is beyond the scope of this restoration plan. The State believes, however, that it is accounting for those funds in an appropriate manner and observes that EPA is also overseeing the expenditures of those funds. Responding to BSB's comment that the SSTOU fund "should address both remediation and restoration where possible," the State notes that the remediation at this site will, in all likelihood, have the effect of restoring some natural resources. It should be further noted, however, that it will not be possible to tap into the SSTOU fund for projects which are "strictly restoration" in nature until the remediation is completed and it is determined that no further money from the SSTOU fund is needed for remediation. As for BSB's comment on the Greenway, again it is beyond the scope of this Plan to address specific restoration projects which may be proposed to be funded pursuant to this Plan.

COMMENT: BSB comments on Chapter 1, page 4, the use of the term "restore" or "restoration" to represent the four types of actions authorized can be misleading, and The Project Green Steering Committee ("PGSC") commented that the definitions of restoration, rehabilitation, replacement and acquisition should be tighter. (Letter 19G, 22E.)

RESPONSE: These comments are noted. The Plan, at page 2, explains that: "For the sake of convenience, the words "restore" and "restoration," as used in this document, generally refer to all types of actions a Trustee is authorized to take under CERCLA to 
address injuries to natural resources, i.e. restoration, rehabilitation, replacement and acquisition of equivalent resources." Hence, the Plan uses the terms, "restore" or "restoration," to represent the four types of actions noted above in order to make the Plan more readable and shorter in its length. The State, in the Plan, has attempted to describe what is encompassed by these terms in a number of places. In fact, much of Chapter 5 is devoted to identifying the types of actions that constitute restoration, rehabilitation, replacement and/or acquisition of equivalent resources.

COMMENT: BSB comments on Chapter 1, page 8, the constraint imposed by the settlement on Restoration Funding regarding bull trout should also focus on westslope cutthroat trout, and all fish restoration projects must be conducted in the Basin. (Letter 19H.)

RESPONSE: The requirement that the State spend at least $\$ 500,000$ on bull trout restoration was imposed, at DOI's insistence, by the SSTOU Consent Decree. No such constraint was imposed on the State regarding westslope cutthroat trout; thus, the Trustee is free to decide over the course of the restoration process how much money, if any, should be spent specifically on restoration of westlope cutthroat trout.

COMMENT: On Chapter 4, page 39, BSB questions whether the "Ecosystem Consideration, Coordination and Integration" criterion was already covered under the Stage 1 Criteria and suggests that this criterion creates an unnecessary bias toward projects that restore resources vs. replace. (Letter 19DD.)

RESPONSE: While the State agrees that the "Ecosystem Considerations, Coordination and Integration" criterion may, to some degree, overlap with some of the Stage One Criteria, the State believes that this is an important policy which should be clearly set forth in the Plan. The State does not believe that this criterion, in and of itself, creates a "bias toward projects that restore resources vs. replace." However, the criterion on page 38, labeled "Actual Restoration of Injured Resources," does state that "the actual restoration of resources that were injured should be given priority."

COMMENT: BSB comments that pages 39-40, having separate criteria of land acquisition projects appears to imply that the use of the "restore" and "restoration" in the general policy criteria do not apply to acquisition projects and asks whether these criteria are extra, or mutually exclusive from the general policy criteria. BSB states that in any event a threshold criterion for any land acquisition projects must be its location within the Basin. (Letter 19EE.)

RESPONSE: The "Land Acquisition Criteria" set forth on pages 39-40 are additional criteria which are applicable to proposed acquisition projects; the other criteria set forth on pages 35-39 shall also be considered in evaluating such projects. Text will be added to the Plan to clarify this. Also, as a matter of policy and for the reasons 
previously set forth in these responses to comments, land and interests in land to be acquired pursuant to this Plan must be located within the UCFRB.

COMMENT: Robert E. Benson comments that on pages 5 and 23 there is no mention of the Milltown water supply replacement, that this is an integral part of the superfund picture, and the uncertainty of the arsenic plume and the potential effect on groundwater should remain as part of the State's concerns. (Letter 29C.)

RESPONSE: The State will make mention of the Milltown water supply replacement in the Plan. The State's injury assessment for the Milltown area did find that groundwater in the area is contaminated with arsenic. The State's expert, however, believes that the arsenic plume is fairly well defined and stable in its location.

COMMENT: Mr. Benson comments on examples provided in Chapter 5 and states that the page 42 example of collecting and treating contaminated groundwater seems to be a remedial action, and that the page 43 example of acquisition of land for hunting does not address the damage to the land or habitat for non-game wildlife. Mr. Benson expresses similar concerns with access to unimpaired tributary streams and questions whether these types of actions will be used to avoid dealing with the really tough contamination situations. (Letter 29I.)

RESPONSE: The State agrees that collecting and treating contaminated groundwater can be an appropriate remedial action. This type of action, however, can also restore the groundwater to baseline conditions and, therefore, could also be an appropriate restoration action. As for the example of acquiring land for hunting, the State observes that such an acquisition most likely would have the additional benefit of providing habitat for non-game wildlife. It is true that acquisition actions do not directly deal with the actual restoration of the injured resources; however, this does not preclude such projects under CERCLA (although the Plan does indicate that it is the general policy of the State to give priority to the actual restoration of resources -- see Plan at p. 38).

COMMENT: Margie Smith comments that restoring the Washoe Smelter Stack is an important project to the Anaconda area. (Letter 30B.)

RESPONSE: Again, it is beyond the scope of this Plan to comment on the appropriateness of specific restoration projects. The State observes that if restoration of the Washoe Smelter Stack is proposed to be funded under this Plan, the applicant will have to describe how this would restore natural resources which were lost, or natural resource services which were impaired, as a result of ARCO's and its predecessors' releases of hazardous substances. 
COMMENT: Vicki Watson comments that she is happy to see proposed procedures and criteria focus on restoration (and not economic development) and that they take a watershed approach to restoration action in the Clark Fork. (Letter 31A.)

RESPONSE: Ms. Watson's comments are noted.

COMMENT: Beverly Dupree comments that she would like to see the Plan mention more specifically conservation easements, and would like to see this tool used in the Plan's implementation. (Letter 32A.)

RESPONSE: Conservation easements are recognized as a legitimate restoration tool in the Plan (see pp. 39-40).

COMMENT: Bill Janecke questions whether drainages such as the Little Blackfoot River, Flint Creek, Rock Creek, etc. will be acceptable areas for project applications within the first two granting cycles and what is the most downstream location eligible for grants in the first two granting cycles? (Letter 34J.)

RESPONSE: Since these drainages are part of the UCFRB, they may be acceptable sites for restoration projects which could be funded under this Plan, provided it can be shown that it is likely such projects would restore injured natural resources, such as those in the Clark Fork River. Such projects could be approved during the first two annual cycles. The most downstream location eligible for restoration grants would be at Milltown Dam.

COMMENT: Fritz Daily comments that Chapter Five precludes the Butte Project Green Committee from presenting their proposal for a new Columbia Gardens type park in Butte, precludes the development of any such future type proposals, and suggests that the Settlement is only designed to address restoration on the Clark Fork River and Silver Bow Creek. (Letter 36C.)

RESPONSE: Chapter 5 does not preclude any applicant from presenting any restoration proposal for consideration for funding under this Plan. The chapter is intended to help applicants understand what types of restoration projects will be eligible for funding but is not intended to preclude any specific project as that would be beyond the scope of this Plan. Whether a particular project constitutes "restoration, rehabilitation, replacement or acquisition of the equivalent" of the natural resources which were injured or lost is a legal and factual consideration which must be determined on a case by case basis in reference to the details of specific projects which are proposed. Furthermore, Chapter 5 does not suggest that the Restoration Fund can only be used to address restoration on the Clark Fork River and Silver Bow Creek. 
CATEGORY 5: Chapter 3 Planning Procedures. The State received 13 comments from 5 persons or entities generally addressing the restoration planning procedures set forth in Chapter 3. These various comments are listed below and responded to individually:

COMMENT: MWQAC hopes that the team assembled to review and select restoration projects will include people with appropriate scientific expertise and experience in the UCFRB. (Letter 11H.)

RESPONSE: The team assembled to review and recommend restoration projects for funding will include people with appropriate scientific expertise and experience in the UCFRB.

COMMENT: ADL comments that the Restoration Funding process in Chapter 3 may become cumbersome and convoluted, and that the experience and expertise of the Department of Commerce may be used where grant applications have been received and acted upon without any significant problems, or that the people who have been working with this Superfund problem for quite some time, including the members of the Advisory Council, should be used. (Letters 13C; 14C.)

RESPONSE: The State understands that the process for making restoration funding decisions described in Chapter 3 may seem somewhat cumbersome. The State, however, does not believe that the process will be as difficult as it may seem to ADL. Also, it should be understood that many of the requirements of Chapter 3 were not devised by the State of Montana but have been imposed by CERCLA, the Consent Decrees and other provisions of law. The Montana Department of Natural Resources and Conservation ("DNRC"), the Department of Commerce and other departments within the State with grant programs were consulted in the preparation of this Plan and had significant input. In preparing the Plan, the State also consulted with and incorporated a number of the recommendations of members of the Advisory Council and those who have been working on Superfund.

COMMENT: ALDC comments that it foresees inherent conflict arising in the outlined process, and suggests streamlining the process. (Letter 16A.)

RESPONSE: See the response immediately above.

COMMENT: ADL comments that the NRDP staff should not be in a position of both reviewing proposals and requesting RFPs for other projects. (Letter 14B.)

RESPONSE: The State disagrees with this comment. In fact, the Trustee's staff, i.e. the NRDP, because of its familiarity with the injured natural resources and the restoration process, will be in a good position to request RFPs for projects which the 
State believes are necessary to restore the injured natural resources but have not been proposed by other applicants. In fact, the suggestion that the NRDP be allowed to request proposals came from certain members of the UCFRB Advisory Council.

COMMENT: ALDC appreciates the flexibility suggested in the reviewing process, which may require additional guidelines as the process evolves. (Letter 15F.)

RESPONSE: The States appreciates the comment and agrees that the procedures as set forth in the Plan will evolve over time.

COMMENT: ALDC comments that there should be an open time period for accepting "white papers" describing potential projects, to bring to the attention of the Council an opportunity that may have to bypass the regular procedure and grant cycle. ALDC proposes the following framework for processing white papers: Staff would review all white papers, making appropriate comments and forwarding these to the Advisory Council for review. The Policy Council should develop a framework of projects, invite pre-applications, and direct staff to develop a pre-draft restoration plan based on framework and the pre-applications submitted. The Council would then evaluate the pre-draft restoration and submit it to the public for comments. Based on comments from the public, and under the direction of the Council, the staff would then revise the work plan and submit it to the Trustee Council for recommendation. The Policy Council would then submit recommendations to the Governor. ALDC notes that this process could occur in a quarterly, semi-annual or annual basis. (Letter 16D.)

RESPONSE: The State appreciates that there is merit in a number of the suggestions in this comment as to the shape the planning and decision making process should take. It would seem, however, if the State were to adopt these suggestions, it would have to abandon the specific process set forth in the Plan and completely rewrite this section of the Plan. While the State recognizes there are other possible ways of going about this process, including the one suggested here, at this point in time the State is not inclined to make this change. Furthermore, the State believes that the net result of the process suggested by ALDC, in terms of restoration projects finally approved for funding, would be quite similar to the results of the process set forth in the Plan.

The State has incorporated some aspects of the suggestions provided by ALDC with the addition of a pre-application process in the Plan. This process will help applicants determine whether a proposal may be an appropriate restoration project before proceeding with detailed proposal preparation.

COMMENT: BSB comments on Chapter 3, page 29, that it may be better (than the "initial application screening") to establish a formal "Pre-Application" step, whereby prospective applicants could get a more formal "heads-up" from the State on the viability of a project before going through the more difficult process of preparing a comprehensive 
proposal, and there should be consultation with the governing body in the area where a project is proposed to avoid conflict with local work that may be planned or underway independent of projects funded through the NRD program. (Letter 19P.)

RESPONSE: As stated in its response to the comment immediately prior to this comment, the State agrees that there should be a pre-application process set forth in the Plan. The State does not agree that the pre-application process should be a substitute for the initial screening on page 29. That is because obtaining advice on whether a conceptual plan would be an acceptable restoration project is quite different than complying with the minimum qualifications, as set forth on page 29 , with respect to a definite proposed project. The State also agrees that a project applicant should consult with the governing body in the area where a project is proposed to avoid conflict with local work that may be planned or under way. Text will be added to the Plan which will incorporate this concept.

COMMENT: BSB comments on Chapter 3, page 30, regarding NRD staff consultation, and questions why it will be mandatory to consult with DFWP on proposed fish projects and elective to consult with others on non-fish projects. BSB questions how consultation will be handled on projects proposed by state agencies and asserts that there appears to be a strong potential for a conflict of interest on projects proposed by state agencies. BSB further questions how public comment will extend to the proposed project and asks whether public comment late in the evaluation process can kill a project after it has been reviewed under the criteria and recommended for funding. (Letter 19R.)

RESPONSE: The State believes it is important to consult with the Department of Fish, Wildlife \& Parks ("DFWP") on all projects that will affect fish or wildlife because the management and control of all fish and wildlife within the State is within the jurisdiction of the department. Projects proposed by State agencies will be handled similarly to projects proposed by other entities. The State does not believe that there will normally be any conflict of interest as to projects proposed by State agencies unless the director of the department or an employee of the agency working on the project has a personal interest that may be benefited by the project. State agencies are, in essence, arms of the Trustee, and in proposing and implementing restoration projects they do so, in effect, as the Trustee. Under CERCLA, it is the responsibility of the Trustee to develop restoration plans. A Trustee does not have an inherent conflict when he or she executes his or her responsibility under a trust.

If there is the perception, on BSB's part, that a State agencies may seek to perform their normal agency functions using the Restoration Fund, the State directs the commentors to the criterion set forth on page 40, "Normal Agency Functions." The State will clarify and expand this criterion so that it is clear that this is applicable to all governmental agencies and to all proposed projects (not just monitoring and research projects). Under this criterion, the State will not use its Restoration Fund to fund 
activities for which a governmental agency would normally be responsible or would receive funding in the normal course of events.

Finally, public comment on the proposed annual Restoration Work Plan will be considered by the Trustee Restoration Council prior to finalizing the proposed annual work plan and submitting it to the Governor; this is a statutory requirement. In considering public comment, the Trustee Council could very well eliminate a proposed project from the work plan.

COMMENT: BSB comments that there appears to be an inherent conflict for the State to reserve the authority to approve all designs and then claim indemnity from any liability for projects that do not work. (Letter 19V.)

RESPONSE: The State does not believe that there is any conflict for it to reserve authority to approve all designs and then require that the State be indemnified from liability for the projects it approves. This is a prudent measure on the part of the Trustee necessary to protect the trust corpus which is, in essence, the property of the people of the State of Montana. The State, in fact, imposes similar requirements on other types of contracts where work is being performed for the State.

COMMENT: BSB comments that the NRD staff role, beyond their participation in the project selection process should be limited and that the burdens of project design, construction, oversight and overall implementation should be placed on the applicant to avoid creating a perpetual money machine for consultants. (Letter 19W.)

RESPONSE: The Plan at pages 33-34 sets forth, in general terms, what the NRDP's role will be in project implementation, follow-up and monitoring. At this point in time, the text in this section of the Plan will not be changed. The burdens of project design, construction oversight and overall implementation are on the applicant by virtue of the process incorported in the Plan where applicants submit and execute proposals. The State has a duty to ensure projects are implemented as proposed and approved. The State agrees that over time it should attempt to limit its role in this regard to the extent prudent while still protecting the rights and interests of the State, including the Restoration Fund. The State expects that over time the precise nature of the NRDP's role in this regard will evolve, and in future years this section of the Plan will be amended to better reflect and more precisely define this role.

COMMENT: Robert E. Benson questions whether the committee will have time to really evaluate proposals early next year, and conversely will those who propose projects get a fair and informed judgement on their proposals. (Letter 29F.)

RESPONSE: The State agrees that the startup of this program during the first year will take additional time because of the State's lack of experience in implementing such a 
process. It is for this reason that the State, on page 32, has indicated that it intends to use the first year of this restoration process as a "pilot year" to test the process it has devised. During this pilot year, as the Plan indicates, the State will allocate no more than \$7 million from the Restoration Fund for project funding (an amount which is more than a million dollars less than the amount of interest which is currently accruing on the Fund each year). After further considering this matter, including this comment, the State has also decided to limit the number of projects which it will approve (with the understanding that the total cost of these projects could amount to significantly less than $\$ 7$ million). To do this, the State will add to the Plan an initial screening criterion which will be applicable only in the pilot year. Under that criterion the applicant will have to demonstrate why their proposals should be funded during the pilot year and why there is good reason their proposals cannot wait for funding in following year(s). Second, the State will limit the number of projects it approves for funding in the pilot year to a total in the range of ten to twenty. By limiting the pilot year in this additional way, the State believes that it will have enough time to complete a fair and informed evaluation of the proposals.

CATEGORY 6: Need for Specific Goals and a Comprehensive Plan. The State received 21 comments from 12 persons or entities suggesting that the State incorporate into the proposed plan a comprehensive restoration plan, setting forth watershed-scale restoration needs and goals that will serve as a guide to project selection and restoration work in the UCFRB. (See Letters 3A, B; 4A; 5A; 7E, F; 8B; 9C; 10C, E; 11D, E, F; $16 \mathrm{C} ; 19 \mathrm{~F}, \mathrm{~S} ; 29 \mathrm{E} ; 31 \mathrm{~B}, \mathrm{C}, \mathrm{D}, \mathrm{E}$.) Some of the Category 6 comments included explicit suggestions regarding such specific goals and a comprehensive plan, including the following:

COMMENT: The Tribes comment that watershed-scale guidance is needed to address the risk that individually awarded projects will not be additive or complementary to achieve overall restoration goals for the UCFRB, and that performance criteria for fund distribution are needed to meet watershed-scale restoration needs. (Letter $3 \mathrm{~A}, \mathrm{~B}$.)

COMMENT: The Tribes comment that specific criteria are needed to set resource condition benchmarks and specific methods for measuring restoration progress or success, including an adaptive planning process in order to know how and when to adopt changes that will maximize the likelihood of success of restoration projects. (Letter $3 \mathrm{C}$.)

COMMENT: The UCFRB Steering Committee comments that the Advisory Council should develop a road map in a public process over a relatively short period of time such as six months to a year. (Letter 5A.)

COMMENT: TU comments that annual work plans should identify mileposts for each objective to ensure that restoration needs, rather than random proposals, drive annual planning, and that the NRDP break the UCFRB into distinct geographic units and 
focus annual plans on specific geographic areas, with the priorities based on the progress of Superfund remedies. (Letter 7F.)

COMMENT: MEIC comments that the Plan should have very specific, measurable goals for restoration such as acres of restored riparian habitat, number of trout per mile, and volume of surface and groundwater restored. (Letter 10E.)

COMMENT: MWQAC and Robert E. Benson comment that TU has prepared a comprehensive document setting forth restoration priorities on the UCFR, and that this document is a good general blueprint for restoring fisheries in the Basin. (Letters 11F; 29E.)

COMMENT: ALDC comments that a 5 to 10 year vision should be developed as a guide to desired outcomes of restoration efforts. (Letter 16C.)

COMMENT: Vicki Watson comments that even though some of the RODs are not complete and portions of the lawsuit are yet to be settled, the State could begin the process of defining goals of local citizens and identifying potential impacts of alternative types of projects. If comprehensive planning waits until after RODs are issued, the State should ensure that only the interest generated by the settlement is spent on projects until then, and some of the settlement funds should be spent to develop a comprehensive plan involving local groups and science professionals with long term experience with the river. (Letter $31 \mathrm{C}, \mathrm{D}$.)

RESPONSE TO CATEGORY 6 COMMENTS: The State appreciates the need for a comprehensive plan setting forth watershed scale restoration needs and goals which would serve as a guide against which to apply criteria for project evaluation and selection. The State further agrees that the adoption of such a plan, together with specific restoration goals, is needed for the various reasons set forth in the comment letters. The State would point out, however, that the basic underlying goal of the restoration process is set forth in the Plan. That goal is to restore the natural resources which were lost and services which were impaired as a result of the releases of hazardous substances from ARCO's and its predecessors' mining and mineral processing operations. Chapter 2, in fact, is devoted to a description of the injured resources which are to be the subject of the restoration projects to be funded. One of the principle reasons the State has not developed a comprehensive plan to accomplish this underlying goal is that a number of the more significant RODs, including those for the Clark Fork River and the Butte Priority Soils Operable Units, have not been issued and the State's natural resource damage claims involving these two sites in particular, and also the Smelter Hill Area Uplands site, have not been resolved. CERCLA itself provides for the issuance of a ROD at a site before the issuance of a NRD restoration plan for the site (admittedly, this requirement does not apply to the CFRB NPL sites because the State's NRD litigation was "grandfathered" before this provision was added to the Superfund law). The State 
believes that it would be very difficult, premature, and an inefficient use of the Restoration Fund to develop a comprehensive plan for restoring the natural resources in the Basin until these RODs are issued and the litigation is resolved. Moreover, preparation of such a plan could interfere with the State's litigation goals and with EPA's RI/FS process involved in developing the RODs for these sites.

Some of the public comments on this issue recognize the problem with developing a comprehensive plan at this time. These commentors, however, suggest that at least the State could begin developing specific goals by which restoration of natural resources could be measured. It is suggested, for example, that the State should establish a goal for the number of trout per mile in the Clark Fork River and volume of surface and groundwater to be restored. The State believes this suggestion has merit and will, at the request of the UCFRB Advisory Council, initiate a cooperative effort with the Council to develop Basin-wide goals that will not interfere with the ongoing NRD litigation and EPA Superfund process.

In a sense, goals for natural resource restoration have already been established as part of the State's NRD injury assessment being used in the litigation. For each injured resource, the State, as part of that assessment, was required to establish "baseline conditions," i.e., the condition the resource would be in but for the release of the hazardous substances. For example, the baseline conditions which were established for the Clark Fork River included the number of trout per mile which would be expected in the river absent the effects of hazardous substances. It is the goal under CERCLA to restore the injured resources to baseline conditions. Thus, a goal for restoration of each injured resource has already been established by the State. The State agrees that these goals should be reexamined and other goals should be set as part of the restoration planning process in the future.

Once the RODs have been issued and the litigation is resolved, the State will be in a much better position to know what the remediation will entail, how much money the State will have to spend on restoration and, therefore, will be in a significantly better position to develop a comprehensive plan. In developing that plan the State will solicit the advice of the Advisory Council, input from the scientific community, DOI, EPA, the Tribes, and from all other interested entities and members of the public. Among the many documents that the State will consider will be the report prepared by Trout Unlimited entitled, "Restoring the Upper Clark Fork: Guidelines for Action" (April 1999). In the meantime the State believes that it is important to proceed with restoration projects which the people of the Basin and others believe are appropriate to fund at this time in order to restore the Basin's natural resources. Ms. Watson's suggestion that if "comprehensive planning" must await the issuance of the RODs, "the State should insure that only interest generated by this settlement is spent on projects, until then" is well taken and reflects the intention of the Trustee at this time. 
CATEGORY 7A: Structure of NRDP. The State received 15 comments from 13 persons or entities regarding the structure of the Natural Resource Damage Program ("NRDP"). (Letters 7B; 12D; 15C; 17A; 18C; 19D/N; 20C; 21G; 22G; 23C; 25C; 26C; 27F, $\mathrm{H}$; 35E.) Many of those comments stated that the NRDP litigation and restoration functions should be split. Other specific comments relating to the structure of the NRDP included the following:

COMMENT: Bryan Holland comments that he hopes the State carefully considers how the restoration program should be structured. (Letter $27 \mathrm{H}$ )

COMMENT: Powell County comments, relative to page 26, that the NRDP has fulfilled its charter, and that a different entity, whose sole purpose and expertise lies in restoration should replace the NRDP. Fritz Daily joins Powell County in this comment stating that if the Helena bureaucracy was taken totally out of the process, we would all be better off. (Letters 12D, 35E.)

COMMENT: TU comments that it likes the State's recommendation that the NRD program have a continued role in helping implement the restoration plan because some of the expertise developed in the NRD program could play an important role in helping ensure settlement funds are spent efficiently, effectively and for the purposes related to the original claim. (Letter 7B.)

RESPONSE TO CATEGORY 7A COMMENTS: Since the UCFRB Restoration Procedures and Criteria does not deal with the structure of the Natural Resource Damage Program, the State believes that these comments are outside the scope of this document. Having said that, the State does not believe, for the reason cited by Trout Unlimited and for several other reasons, that it makes sense to split up the NRDP. The State does believe that there is some merit to the suggestion that the NRDP be restructured; in fact, the State is in the process of doing just that. The State has just hired a new NRDP employee to fill the position, "UCFRB Restoration Program Chief." The Restoration Program Chief will be in charge of the restoration component of the NRDP. The NRDP, in consultation with the Advisory Council and other entities, will make recommendations to the Trustee Restoration Council and to the Governor on the annual restoration work plan and will be responsible for overseeing implementation of the projects and expenditures from the Restoration Fund. It is envisioned that when the litigation is for the most part resolved, the Restoration Program Chief will become the supervisor of the entire Program. In the meantime, it is necessary to keep both the litigation and the restoration components of the NRDP together for several reasons.

The litigation component of the NRDP is continuing to develop evidence and prepare for trial of the remaining restoration claims valued at a total of about $\$ 180$ million. It is also involved in working with EPA on the Clark Fork River and Butte Priority Soils RI/FS processes and in litigating ARCO's site specific water quality 
petition before the Montana Board of Environmental Review. It is also responsible for seeing that the State and others fulfill their responsibilities under the Consent Decrees.

To split the NRDP apart at this time would be a mistake for both efficiency and strategic reasons. Presently most of the NRDP. employees work on both components of the Program. Thus, keeping the NRDP together allows for the efficient allocation of employee time and other resources (such as computers, office space, etc.). Also NRDP personnel have unique experience relevant to each component of the Program. Hence, keeping the NRDP together saves the State the cost of developing (or purchasing from consulting firms) additional such expertise which would be necessary for both litigation and restoration purposes if the NRDP were split apart. Finally, and probably most importantly, keeping the NRDP together assures that Program's efforts will be coordinated and that the State's litigation strategy will not be compromised by potentially conflicting actions of the restoration component of the Program.

The NRDP was originally created by Governor Stephens and the legislature as a vehicle for preparing the natural resource damage assessment of the UCFRB, including a restoration plan, and for pursuing the litigation against ARCO. The idea was that the Governor and the various State agencies with a distinct interest in the matter could best cooperate in this pursuit by having one program, with legal, scientific and administrative expertise, represent the State as a whole. It was always contemplated that when the lawsuit was over, the NRDP would be involved in administering the expenditures of the damages recovered on restoration projects. This idea has served the State well up to this point in time, and the State believes it will continue to serve it well into the future.

CATEGORY 7B: Location of NRDP Office. The State received 9 comments from 8 persons or entities to the effect that the NRDP office should be located in the UCFRB. (See Letters 19D/N; 20C; 22G; 23D; 24B; 25C; 26B; 27G; 30A.) All but one of these comments came from those who also believe that the NRDP should split apart.

RESPONSE: This comment also goes beyond the scope of the draft UCFRB Restoration Plan Procedures and Criteria. Having said that, the State continues to believe that the principal office of the NRDP should remain in Helena. (This is not to say that a NRDP satellite office in the Basin would not make sense once work in the field begins.) There are various reasons supporting this position. First, as was explained above, the NRDP has both litigation and restoration components which must work together. It is essential that the NRDP remain in Helena in order that the State may continue to pursue the litigation and, at the same time, administer the restoration program. Helena is the State's capitol and the location of the Governor's office, the Attorney General's office, and the various State agencies i.e., DEQ, DFWP and DNRC, which the NRDP represents at the litigation. To effectively pursue the litigation and restoration planning, it is important that the NRDP have convenient and immediate access to these offices and agencies together with the other State and federal agencies 
involved in the Superfund and restoration process, including, in particular, EPA. Furthermore, Helena is considerably closer to the location of the Court, i.e., Great Falls, handling Montana v. ARCO and is also the location of two proceedings relating to the litigation, namely the EPA RI/FS processes and the proceeding involving ARCO's petition for site specific water quality standards. Moreover, the NRDP's employees currently live in the Helena area. It would be unfair to require them to move unless there is a compelling reason to do so.

.It has been argued that if the NRDP office were moved to the Basin, better restoration decisions would be made. When analyzed, this argument is not compelling. How is a better result going to be achieved by requiring the State employees to perform his or her work in Butte, for example, rather than in Helena? A reasonable counter argument can be made that Helena, or some other city outside the Basin, is a better location for the office because such cities do not have any particular interest in having restoration projects located at any particular site in the Basin.

Finally, it should be recalled that it was the State, acting through its Governor, that recovered the monies on behalf of all of Montana. The scientific studies and litigation which finally resulted in the settlement were financed by appropriations from the State's General Fund and Coal Tax Fund (which were subsequently reimbursed from the settlement recovery). In addition, the amount of damages claimed were based upon the loses of all Montanans, not just those living in the Basin. No one would deny that the views of the citizens residing in the Basin do not deserve special consideration in determinations regarding the Restoration Fund. But the injury was to the State's natural resources, and it was the entire State which, at considerable risk, pursued the litigation and recovered the settlement monies. That recovery is under the stewardship of the Governor. The Governor is headquartered in Helena, and it makes sense that the Governor's staff, responsible for administering this fund, should also be located in Helena.

CATEGORY 8: Participation of Tribes and DOI in Planning Process. The State received 13 comments from 4 persons or entities regarding the DOI's and Tribes' participation in the restoration planning and decision-making process as set forth in the Plan. EPA commented that it supports the Tribes' and DOI's participation. The other comments were as follows:

COMMENT: The DOI comments that Figure 2 does not indicate how the MOA provisions allowing trustees an opportunity to review and comment on restoration plans of other trustees at least 30 days before the Plans are submitted for formal review, and at least 30 days before the Plans are finally approved will be accommodated by the State. Specific provisions should be made for the trustees to participate in the proposed State restoration planning process. (Letter $2 \mathrm{~A}$.) The DOI and the Tribes comment that they should be provided an opportunity to participate in the NRDP meetings and evaluations 
which will occur during the period April-June and which would be held for the purpose of conducting the activities identified in the Figure 2 box labeled Natural Resource Damage Program ("NRDP") Evaluates Applications and Prepares "Pre-Draft Restoration Work Plan". (Letters 2B, 3E.)

RESPONSE: In responding to this comment it should first be observed that the MOA does not refer to the parties thereto, i.e., the State, the Tribes and DOI, as "Trustees." While each of these parties have asserted that they are each Trustees of certain natural resources in the CFRB, the MOA expressly provides: "No party to this agreement, by signature or other participation in this agreement, is acknowledging the trusteeship of any other party to this agreement."

The State acknowledges that Figure 2 of the Plan does not necessarily provide explicit details of how DOI and the Tribes will be given an opportunity to review and comment on the State's annual restoration plans; this figure must be read in conjunction with the MOA itself and the text in the Plan (particularly pages 30 and 31). The Plan at page 30 provides that the Tribes and DOI "will be afforded significant roles in restoration planning at various stages of the review and decision making process beginning at the application/evaluation stage." The Plan goes on to explain that the Tribes and DOI will be given copies of all qualified project applications, and that subsequently the State, through the NRDP, will meet with the Tribes and DOI on an "as needed basis and at least once during the yearly application review cycle" to discuss the proposed projects. By this, the State envisions that there will be at least one meeting with the Tribes and DOI which, if the parties so wish, will be separate from the State's meetings with the Advisory Council to discuss the State's preparation of the pre-draft Restoration Work Plan. Thereafter, these parties may meet with the State during the annual cycle process whenever the parties and the State deem it appropriate. Text will be added to pages 30 and 31 and Figure 2 to further clarify this point.

COMMENT: The DOI and the Tribes comment that they should be provided an opportunity to participate in the Trustee Council and the NRDP planning meetings which will occur in September while conducting activities identified in the Figure 2 box labeled Trustee Restoration Council Considers Pre-Draft Work Plan and Directs NRDP To Prepare "Draft Restoration Work Plan". (Letters 2C, 3F.)

RESPONSE: DOI and the Tribes may participate at the meeting at which the Trustee Restoration Council considers approving the pre-draft Restoration Work Plan. Figure 2 already indicates that the Tribes and DOI may meet with the NRDP on the predraft Restoration Work Plan.

COMMENT: The DOI and the Tribes comment that they should be provided an opportunity to participate in the planning meetings by the NRDP and the Trustee Council which will take place in October and November while conducting activities identified in 
the Figure 2 boxes labeled NRDP Responds to Public Comment, Revises Draft Work Plan and Submits It To Trustee Council, and Trustee Council Finalizes Proposed "Restoration Work Plan" and Submits it to Governor for Approval. (Letters 2D, 3G.)

RESPONSE: The Tribes and DOI may participate in the meeting at which the Trustee Council finalizes the proposed "Restoration Work Plan. The State does not, however, anticipate any other restoration planning meetings in the October/November time frame during the time the NRDP is preparing its responses to public comment. Presumably the Tribes and DOI will submit any further comments they have on the Restoration Work Plan during the public comment period and the State, through the NRDP, will subsequently respond to those comments.

COMMENT: The DOI and the Tribes comment that they should be provided at least a 30 day period for review and comment on the draft Restoration Work Plan before it is released to the public in September, as shown in the Figure 2 box labeled Draft Restoration Work Plan Released for Public Comment. (Letters 2E, 3H.)

RESPONSE: The Tribes and DOI will be provided a 30 day period to review and comment on the pre-draft Restoration Work Plan before it is approved by the State and released for public comment as the draft Restoration Work Plan. This process is already illustrated in Figure 2. In fact, the one of the principal reasons the State is preparing what is called the a "pre-draft Restoration Work Plan," is to allow DOI and the Tribes, along with the Advisory Council, an opportunity to review the State's proposed restoration plan at least 30 days prior to its formal submission for public comment. The MOA does not provide that DOI and the Tribes be given an additional 30 days to review the proposed restoration plan prior to its release for formal public comment.

COMMENT: The DOI and the Tribes comment that they should be provided at least a 30 day period for review and comment on the proposed Restoration Work Plan after it is finalized by the Trustee Council but before it is submitted to the Governor for approval in November, as shown in the Figure 2 box entitled Trustee Council Finalizes Proposed Restoration Work Plan and Submits it to Governor for Approval. (Letters 2F, 3I.)

RESPONSE: The NRDP will respond to public comment, revise the draft Restoration Work Plan and submit it, as the proposed final Restoration Work Plan, to the Trustee Council during the November time period. It is a possible that there may be as many as 30 days between the time the NRDP submits the proposed final Restoration Work Plan to the Trustee Council and the time the Trustee Council submits it to the Governor. (The precise schedule will be made known to the interested parties and public soon after the public comment period closes.) At the meeting during which the Trustee Council makes its final decision, the State will accept recommendations on the work plan. Subsequently, however, there will not necessarily be a 30 -day period between the 
time that the Trustee Council sends the proposed Restoration Work Plan to the Governor and the Governor's decision. It envisioned that in making his or her final decision on the work pian, the Governor shall consider the record that was before the Trustee Council at the time it made its final recommendation, including public comment and the recommendations and comments of the Advisory Council, EPA, DOI, and the Tribes.

The State observes that there are not enough 30 day time periods in a year to accommodate all of the additional 30 day periods for review which have been suggested by the Tribes, DOI, EPA, the Advisory Council and certain other commentors on the Plan. In fact, the State staff will have a difficult time just meeting the various deadlines as it is. Furthermore, the State notes that the project applications submitted for each annual cycle will be available for review by all interested parties at the beginning of April, and the initial proposed restoration plan will be released in the June/July time frame while the final decision will not be made until December. Thus, all interested parties will have many months to review and comment on the proposals prior to the final decision in December.

COMMENT: BSB comments on Chapter 4, page 36 , that more explanation should be provided as to why the "Resources of Special Interest to the Tribes and DOI" criterion should be imposed, asking whether it was the federal mandate to address such resources already addressed as part of the separate settlement with the Tribes and DOI and asking why it is necessary to grant extra weight in these Stage 1 criteria for all projects. (Letter 19BB.)

RESPONSE: As the State has attempted to explain in Chapter 4, this criterion was included as one of the Stage One Criteria which are "required by legal considerations". because the MOA with the Tribes and DOI provides that this should be a consideration when the State prepares its restoration plans. The MOA was part of the settlement and is an appendix to the SSTOU CD.

CATEGORY 9: Monitoring and Research. The State received 11 comments from 10 persons or entities regarding monitoring and research. These comments range from those in support of funding monitoring and research in the UCFRB, to those who would limit or preclude such funding. In more detail, the comments received included the following:

COMMENT: Vicki Watson comments that there is a need for a more coordinated approach to selecting projects, the State needs to ensure that projects selected will not work at cross purposes, and that an overall monitoring plan is needed to evaluate the success of efforts, not a fragmented project-by-project approach to monitoring. (Letter 31B.)

RESPONSE: The draft Plan calls for an examination of the relationship of any proposed project to the overall conditions in the UCFRB. Each project will also be 
considered in regard to how, and to what extent, it will be coordinated or integrated with other actions - ongoing or planned - in the UCFRB. (See Plan at p. 39.) This ecosystem analysis should protect against projects working at cross-purposes in the Basin.

COMMENT: MEIC strongly supports monitoring as an essential part of any resource recovery plan and urges that it include a physical, chemical and biological component to determine whether reclamation goals are being achieved. (Letter 10F.)

RESPONSE: In addition to monitoring requirements that may require data collection and analysis for particular projects, the Plan calls for the State to annually describe the current condition of the natural resources and services. (See Plan at p. 34.) Some measure of physical, chemical, and/or biological monitoring would be likely components of this annual evaluation and status report.

COMMENT: MWQAC is pleased to see funding available for monitoring the success of individual projects and would also like to see a plan for tracking the overall success of the program over the years to ensure that the program goals are being met. (Letter 11E.)

RESPONSE: The Plan contemplates that monitoring will provide information of value for tracking the success of the restoration actions including, whether natural resources are recovering, whether prior actions have improved the condition of the impaired resources, and whether there are any constraints on resource recovery. (See Plan at p. 34.)

COMMENT: The UCFRB Steering Committee commented that the amount of funding available for project development, administration, and monitoring should be capped to ensure that funding is predominantly used for restoration. (Letter 5G.)

RESPONSE: While no current "cap" exists on funding monitoring, project development, or administration, the law requires that the recovered funds are to be spent on restoration of the injured resources. Monitoring and project development may lead to well planned projects. Additionally, only amounts which are reasonably related to restoration planning and evaluation are contemplated as appropriate administrative expenditures. Such expenditures are necessary in order for the State to fulfill its responsibilities with respect to the expenditures of recovered NRD funds. The Plan expresses a reasoned cap; i.e., the State will endeavor to minimize these expenses. (See Plan at p. 45.)

COMMENT: TU comments that the NRD Program should establish strict criteria for screening requests to fund research, recommending that there be a clear showing that proposals target research areas that fill existing data gaps, and that the information gained will benefit restoration activities. TU is concerned that without such criteria, this funding 
will be viewed as a big pot to fund nominally related research conducted by academic institutions as well as consulting and research firms. (Letter 7K.)

RESPONSE: The criteria to evaluate the proposed funding of research projects, as set forth in the Plan at page 40, encompasses much of this comment. In the evaluation, the State will carefully consider the necessity of any particular research proposal. The State does not believe that placing further restrictions on research is warranted at this time. If a large number of research proposals come in, then developing additional criteria to enhance the screening of such proposals may be developed.

COMMENT: Powell County comments that money spent for "Monitoring and Research Criteria" ought to benefit the selection and implementation process. (Letter 12L.)

RESPONSE: The Plan contemplates that monitoring and research will benefit the project selection and implementation process by providing useful information which can assist the State in making informed selection decisions and evaluating the effectiveness of the restoration projects. (See Plan at pp. 40, 45.)

COMMENT: ADL comments that the projects that fall under monitoring and research should be very carefully scrutinized so that some university professor does not create a permanent research project to study the river, that has already been studied to death. (Letter 14D.)

RESPONSE: The comment is appreciated. The monitoring and research criteria should protect against any such occurrence. (See Plan at p. 40.)

COMMENT: ADLC comments that it is concerned that excessive amounts of funds could be spent on research and monitoring activities and not on actual restoration work. (Letter 15G.)

RESPONSE: The Plan expresses the State's preference that the actual restoration of the resources that were injured should be given priority. (See Plan at p.38.) However, monitoring research will provide coordination with other scientific work and will assist with restoration planning.

COMMENT: BSB questions whether the "Monitoring and Research" criteria are "extra," or mutually exclusive of the general policy criteria. (Letter 19GG.)

RESPONSE: Generally speaking the "Monitoring and Research" criteria are in addition to the Stage 1 Criteria and Stage 2 General Policy Criteria. However, certain of those criteria cannot or should not be applied explicitly to research. For example, the "Project Location" criteria would not require that the research actually be performed in 
the UCFRB but only that the topic of the research involve injured natural resources in the UCFRB and their restoration. This will be clarified in the text of the Plan.

COMMENT: MWF and BSC comment that no settlement funds should be spent on research, i.e. no projects should be funded if the sole deliverables are to learn more about the UCFRB. Monitoring should be allowed only to measure the results or benefits of a funded project and should not be a project in and of itself. (Letters 8E; 19GG, KK.)

RESPONSE: The State believes that such a restriction is both unwarranted and unwise as research and monitoring may provide valuable information for restoration planning as well as an evaluation of the effectiveness of restoration projects.

CATEGORY 10: Consultation with EPA and Coordination with Remediation. The State received 9 comments from EPA and 3 comments from three other entities regarding consultation with EPA and coordination of on going or planned Superfund remedies with restoration projects. These comments are as follows:

COMMENT: EPA comments that response measures selected and implemented by EPA and restoration measures selected and implemented by natural resource trustees require coordination and consultation and that early involvement by EPA in the evaluation process to fund restoration projects is essential to ensure an adequate airing of issues related to the interaction of planned or selected response actions and selected restoration projects. (Letter $1 \mathrm{D}, \mathrm{L}$. )

RESPONSE: While this may not always be the case for every project which is proposed for funding, the State generally agrees that restoration measures selected and implemented by natural resource trustees will often require coordination and consultation with the EPA, and EPA involvement should occur early in the selection process to assure an adequate hearing of issues.

COMMENT: EPA comments that it should be added to the list of entities with whom the NRDP meets on an as-needed basis or at least once yearly, as described on page 30 , second full paragraph, and that it should be added to the list of entities to whom the NRDP will provide a pre-draft plan at least 30 days in advance of its submission to the Trustee Restoration Council. EPA additionally proposes lengthening the time period from the proposed 30 days to 60 days, and adding EPA to the commenting agencies described in the first, second and third bullets on page 31. If issues have not been resolved satisfactorily prior to the submission of the final recommendation on the Restoration Work Plan to the Governor, EPA proposes that a specific meeting with EPA and the Governor be added to the bullet list prior to the Governor making his or her decision on the Restoration Work Plan. (Letter 1M, N.) 
RESPONSE: The State agrees to add EPA to the list of entities with whom the NRDP will meet at least once yearly and on an as needed basis as described on page 30 of the Plan and to whom the NRDP will provide a pre-draft Restoration Work Plan at least 30 days in advance of its submission to the Trustee Restoration Council. The State also will add EPA to the commenting agencies described in the bullets on pages 30-31. The State declines to accept EPA's suggestion that the time period should be lengthened from 30 to 60 days. The State points out that EPA will be provided with the applications for restoration project funding in early April; therefore, EPA will have at least four months to consider the restoration proposals before the Trustee Restoration Council considers the pre-draft Restoration Work Plan for approval. The State also declines to set up a specific process whereby EPA would meet with the Governor "if issues have not been resolved satisfactorily prior to submission of the final recommendation on the Restoration Work Plan to the Governor." Like any other person or entity in Montana, EPA has a right to request meetings with the Governor on matters of significant interest to the welfare of the State of Montana whenever it believes such meetings would be helpful and appropriate.

COMMENT: EPA comments that its expertise on feasibility and other technical issues involved with hazardous waste cleanup should be viewed as a resource for use by the State NRDP. (Letter 10.)

RESPONSE: EPA's expertise on feasibility and other technical issues involved with hazardous waste cleanup shall be viewed as a resource for use by the State in making restoration decisions. The State also agrees that NRD trustees should coordinate and consult with EPA on restoration planning matters which may interact with EPA response actions.

COMMENT: EPA comments that adoption of procedures to involve EPA in restoration decision making would necessitate an accurate description of EPA's role in the cleanup process in the beginning section of Chapter 3 and the flow chart of process activities at the end of Chapter 3. (Letter 1Q.)

RESPONSE: The State will add EPA to Figure 2 and will also add the following description of the role of EPA in the cleanup process:

The U.S. Environmental Protection Agency (EPA) is given the responsibility under CERCLA to select appropriate response actions for sites within the Upper Clark Fork River Basin. EPA listed the Anaconda Smelter Site, the Milltown Reservoir Site, the Silver Bow Creek/Butte Area Site and the Montana Pole Site in the 1980s on the National Priorities List, and has engaged in a series of response action cleanups for the combined sites from 1983 to the present. EPA's response action authority requires EPA to select removal actions to address immediate 
threats and remedial actions to address long term solutions which are protective of human health and the environment. EPA is also required to consult and coordinate with natural resource damage trustees when it conducts investigations or sampling, and trustees are required to consider EPA's response actions when they consider the implementation of restoration actions to restore baseline conditions. The State will consult with EPA during each restoration planning cycle as further described below.

COMMENT: EPA comments that it appreciates the State's attempt to highlight the importance of consistency with planned or selected response actions through the proposed criteria on page 36 and 37 ("Results of Response Actions") and page 39 ("Ecosystem Considerations, Coordination and Integration"). The page 39 criterion should be clarified that "actions" means response, restoration and other related actions. The page 36-37 criterion should be expanded to emphasize that projects which can be efficiently coordinated with response projects, such that cost savings can be achieved, will be favored by the NRDP and Governor to ensure that the coordination and consistency issues will be highlighted and seriously considered during the restoration selection processes. (Letter 1R.)

RESPONSE: Page 39 will be clarified that "actions" include response, restoration and other related actions. In addition, a sentence will be added to page 39 to note that projects that can be efficiently coordinated with response and other actions may achieve cost savings. The bullet on page 37 in this criteria states as follows: "The State will evaluate the degree of consistency between a project and a response action looking at whether a project builds on a response action or at the other end of the spectrum, seeks to undo a response action. The State will tend to favor those projects that do the former as opposed to the later." The State sees no reason to revise that statement.

COMMENT: EPA is encouraged that the State recognizes a wide range of eligible restoration actions which are possibly eligible for funding by the State, particularly in the area of aquatic and stream cleanup, and looks forward to a good dialogue about coordination of response and restoration actions in this area to achieve the desired end of a healthy Clark Fork River ecosystem through efforts by the public and both programs. (Letter 1S.)

RESPONSE: The State appreciates this comment and hopes for the same. The State would note, however, that it already has a restoration plan for the Clark Fork River Aquatic and Riparian Resources. That plan was developed in 1995 outside of the annual restoration process being established by this UCFRB Restoration Plan Procedures and Criteria. When EPA issues its ROD for the Clark Fork River Operable Unit, the State will consider whether its restoration plan for the river should be revised. The State's consideration of that matter shall occur outside the process established by this Plan. 
COMMENT: MWQAC comments that it is pleased that the State will consider the extent to which proposed projects are coordinated or integrated with other ongoing or planned actions in the UCFRB and will evaluate projects in the context of the overall ecosystem. (Letter 11C.)

RESPONSE: The comment is noted.

COMMENT: BSB comments that a blueprint for action should be developed to ensure that remediation and restoration projects are accomplished at the same time. (Letter 19F.)

RESPONSE: The State agrees that when possible and appropriate, remediation and restoration projects should be accomplished at the same time since such efficiencies could result in significant costs savings. However, because of the complexity of the Superfund process, and since the State is not in control of the timing of remediation, developing a "blueprint" to assure that remediation and restoration projects are accomplished at the same time would be extremely difficult if not impossible. As set forth in the Plan at page 39, in evaluating proposed projects, the State will consider whether a project is coordinated or integrated with other actions, including remedial actions, which thereby allow the State to take advantage of costs savings.

COMMENT: GSD comments that the General Policy Criteria should explicitly provide that any decisions or work plans developed for projects within the Basin must be consistent with RODs relative to a specific site or resource, including the SSTOU ROD reference to a Silver Bow Creek recreational corridor. (Letter 21C.)

RESPONSE: The General Policy Criteria entitled, "Ecosystem Considerations, Coordination and Integration" provides that the State will consider the extent to which a proposed project is coordinated or integrated with other actions, including EPA response actions. In addition, the criterion set forth at pages 36-37 entitled, "Results of Response Actions," indicates that: "The State will evaluate the degree of consistency between a project and a response action looking at whether a project builds on a response action, or at the other end of the spectrum, seeks to undo a response action. The State will tend to favor those projects that do the former as opposed to the latter." The State declines to go further than this and provide that restoration projects "must be consistent with RODs." Such consistency is not required by law nor may it be a advisable in all instances. For example, a ROD at a particular location could call for no action, while the State may believe it advisable to take some action to restore the natural resources at a site. This is a matter which must be considered on a case by case basis. 
CATEGORY 11: Injury Description. The State received 12 comments from 3 persons or entities suggesting specific revisions of the Chapter 2 injury description. Those comments are as follows:

COMMENT: EPA comments that the expected BPSOU ROD response action described on page 14 may change depending on the conduct of the RI/FS and remedy selection process. (Letter $1 \mathrm{E}$.)

RESPONSE: This comment is noted.

COMMENT: EPA comments that in the fifth bullet describing the SSTOU ROD and ESD, page 16, the phrase "or remediated floodplain" should be added after the word "stream." (Letter 1F.)

RESPONSE: This addition to the text will be made.

COMMENT: EPA comments on page 16, in the concluding paragraph beginning with "Although", first sentence, second line, the phrase "in-situ treated" should be inserted before "tailings." EPA further comments that it disagrees with the conclusion that significant residual injury or environmental risk will remain after the remedy is implemented, this conclusion should be altered to state that a lack of immediate baseline services may result after the remedy is implemented. (Letter 1H.)

RESPONSE: The State will add the word "treated" before "tailings". The State notes EPA's disagreement with the conclusion regarding "significant residual injury." The State points out that it makes no conclusion regarding "environmental risk" and, as for "significant residual injury," the Plan does not state that such injury "will" result but instead states that such injury "may" result. The State declines to make the suggested changes in its conclusion.

COMMENT: EPA comments that the description of the Rocker OU remedy on page 18 should be altered by inserting "Groundwater exposed during excavation of source materials was also treated to remove arsenic" after the second sentence of that paragraph. In addition, the sentence "However, the responsible party (ARCO) remains liable for additional work, if necessary, to prevent plume migration in the adjoining ground waters" should be added to the end of the paragraph. (Letter 1G.)

RESPONSE: These additions to the text will be made.

COMMENT: EPA comments that the description of the 1998 ARWWS ROD on page 19 is accurate according to current design plans, but the sentence, "EPA, in consultation with the Department of Environmental Quality, reserve the ability to change 
the exact design for the Smelter Hill and Stucky Ridge areas based on ongoing sampling and design efforts," should be added at the end of the paragraph. (Letter 1I.)

RESPONSE: In light of this comment, the State will add the following: "It is possible that EPA may change the precise design for the Smelter Hill and Stucky Ridge areas based on ongoing sampling and design efforts."

COMMENT: EPA comments that the description of the WSP RODs and associated response actions on page 21 should add: "The RODs required improvements in the treatment capabilities of the Pond system through lime addition and water retention control, and removed tailings in the Mill Willow Bypass". (Letter 1J.)

RESPONSE: These additions to the text will be made.

COMMENT: EPA comments that Chapter 2 should contain a process description for updating the description of planned or selected response actions, as EPA's remedy selection and remedy implementation processes proceed, so that the criteria regarding response action consistency can be applied clearly through each budget cycle. (Letter 1K.)

RESPONSE: The Plan at page 1 states: "Accordingly during each of the first two years, near the anniversary date of the adoption of the Plan, the State will solicit and consider appropriate amendments to this Plan." Thus, during the first two years of the restoration planning process, the State will update, as appropriate, the description of the planned or selected response actions. Furthermore, the State anticipates that after the first two years it will amend the Plan wherever it is deemed necessary. Significant amendments to the Plan will go through a public comment process. Technical amendments, such as updating the description of planned or selected response actions, will not go through a public comment process and therefore can be more easily made.

COMMENT: ADL comments that it concurs, without exception, with the description of injury in Chapter Two. (Letter 13B.)

RESPONSE: This comment is noted.

COMMENT: BSB comments on Chapter 2 that more graphics, pictures and descriptions of the completed remediation projects should be included. (Letter 19F.)

RESPONSE: Although the State appreciates this comment, in the interest of time and brevity, the State declines to include graphics and pictures describing the completed remediation projects. The State would observe that graphics and pictures of this nature are included in the State of Montana's Natural Resource Damage Assessment reports which are available to BSB and any other members of the public. 
COMMENT: BSB comments on Chapter 2, page 12, regarding the Berkeley Pit, the word "approaches" should be used instead of "reaches" regarding the CWL, to better reflect the remedial action specified in the ROD. (Letter 19J.)

RESPONSE: This revision will be made to the text of the Plan.

COMMENT: BSB comments on Chapter 2, page 12, regarding Butte Area One, that the description perpetuates the false characterization of the historic SBC channel as the present day Metro Storm Drain, and the Parrott Tailings lie along and "northeast" of the historic Silver Bow Creek channel above Harrison Avenue, not "northwest." (Letter 19K.)

RESPONSE: The water course known as the "Metro Storm Drain" generally follows the historic channel of Silver Bow Creek. BSB is correct, the Parrott Tailings lie generally northeast and along the Metro Storm Drain. Revisions to the text will be made to reflect these points.

CATEGORY 12: Decision-making Criteria. The State received 8 comments from 6 persons or entities regarding the Stage 1 and 2 Criteria. These comments will be addressed individually.

COMMENT: TU firmly believes that the Stage 1 screening criteria are necessary for ensuring settlement funds target resources that were the subject of the claim. (See Letter 7D.)

RESPONSE: The State appreciates TU's comment and agrees that the Stage 1 criteria are necessary for ensuring settlement funds target resources that were the subject of the claim, and in so doing, satisfy relevant provisions of law to which the State must adhere in expenditure of restoration funds.

COMMENT: MEIC comments that the State should better define the public support criterion. MEIC does not want this criterion to be a "popularity contest" in which economic development projects are likely to be more popular than a restoration project which may not provide immediate economic gains. (See Letter 10G.)

RESPONSE: The "Public Support" criterion is a Stage 2 criterion reflecting Montana policies to be advanced through restoration funding decisions. This criterion is commonly used in other state administered grant programs to help recognize that the money to be distributed belongs to all of the people of the State, and is an explicit recognition of the importance of the public participation in restoration decision-making. MEIC's fear that this may become a "popularity contest" in which economic development projects are more likely to be funded than restoration projects is unfounded, 
primarily because project proposals will be evaluated pursuant to all of the Stage 1 and 2 Criteria.

COMMENT: Robert E. Benson questions what does the "Public Support" criterion mean. (See Letter 29H.)

RESPONSE: As set forth in the previous response, the "Public Support" criterion is an explicit acknowledgement of the importance of public participation in the restoration decision-making process. Public funds, gained through the settlement of some of Montana's natural resource damage claims against ARCO, will be utilized to effectuate restoration of the UCFRB. Therefore, to promote the Montana policy that the public is involved in and supportive of restoration funding, the State established this specific Stage 2 criterion.

COMMENT: The CFC appreciates the good work the NRDP has put into the document and the Plan provides an excellent overview of injury, the State's lawsuit, and the criteria to be used to determine restoration project funding. (See Letter 9A.)

RESPONSE: The State appreciates the CFC's comment.

COMMENT: Powell County suggests that the Stage 1 Criteria be rearranged to provide for a more sequential process, as follows: the first criterion should be "Results of Response Actions"; the second criterion should be "Technical Feasibility"; the third criterion should be merger of "Relationship of Expected Costs to Expected Benefits, Cost Effectiveness, and Recovery Period and Potential for Natural Recovery" because all three items represent some form of economic analysis; the fourth criterion should lump "Adverse and Environmental Impacts" and "Human Health and Safety"; and the last criterion should merge "Federal, State, and Tribal Policies and Laws" with "Resources of Special Interest to the Tribes and Department of Interior." (See Letter 12I.)

RESPONSE: Although Powell County suggests an alternative arrangement and grouping of the Stage 1 Criteria, the State declines to rearrange the criteria at this time. Through the application process, information will be sought relevant to each of these criteria. Should it become apparent that an alternative arrangement of the Stage 1 Criteria is needed for future funding years, the State may approach this issue again. Also, these criteria are derived primarily from the criteria set forth in DOI's natural resource damage assessment regulations, which trustees are to use when selecting restoration projects. Additionally, the State disagrees that the individual criterion, as set forth in the Plan, should be grouped as Powell County suggests. Although the criteria Powell County suggests grouping are related, it is necessary that they remain distinct from one another, to insure that applicants address each in a precise and thorough manner. 
COMMENT: Powell County suggests that the Stage 2 Criteria be rearranged as follows: the "Relationship Between Service Lost and Service Restoration" should be lumped with "Project Beneficiaries and Collateral Benefits"; "Ecosystem Considerations" and "Matching Funds" should stand alone. (See Letter 12J.)

RESPONSE: Refer to the response to the previous comment.

COMMENT: Under "Land Acquisition Criteria," page 39, Powell County comments that "Desirability of Public Ownership" should be eliminated as a criterion because it is not whether public ownership is desirable but whether habitat protection is achieved, and removing additional land from tax roles for local government is going to be met with significant resistance. Conservation easements or segregation of building development rights could be a positive thing. Also, it is a waste to require the State to conduct its own appraisals because there are professional appraisers licensed by the State to establish fair market value. (See Letter 12K.)

RESPONSE: The State appreciates Powell County's concern that including the "Desirability of Public Ownership" criterion may in some cases hinder efforts to acquire land for habitat protection purposes. By including the "Desirability of Public Ownership" criterion, however, the State seeks to strike a balance between the importance of habitat protection and competing concerns such as those mentioned by Powell County. This is one way that the State hopes to implement restoration actions in the UCFRB that not only restore the injured natural resources, but are favored and supported by the residents of the UCFRB.

The State agrees with Powell County that conservation easements or segregation of building development rights could be utilized in a positive manner as a part of restoration projects. Also, the State is aware that there are professional appraisers licensed by the State to establish fair market value. In some cases, however, it may be necessary for the State to conduct its own appraisals. Accordingly, the State will not limit its options in this regard, at this time.

COMMENT: Bill Janecke comments on Chapter 4, page 39, asking can a requirement of at least a $25 \%$ cost share be required on all grant applications for matching funds and will landowner contributions be evaluated? (See Letter 34K.)

RESPONSE: "Matching Funds and Cost Sharing" is a Stage 2 Criterion and proposals securing funding from other sources will receive a more favorable review, pursuant to this criterion, than projects that do not secure matching funds or cost șaring. Therefore, at the present time, the State does not intend to require a $25 \%$ cost share on all grant applications for matching funds. Landowner contributions that result in the restoration of injured natural resources will be credited as matching funds or cost sharing under the Stage 2 Criteria evaluation. 
CATEGORY 13: Public Participation. The State received 7 comments from 6 persons or entities regarding the role of public participation in the selection of restoration projects, as set forth in the plan. These comments are as follows.

COMMENT: The Advisory Council comments that it recommends increasing the time period for public review and comment and Bill Janecke comments on Chapter 3 , page 31 , asking whether the public comment period may be extended to 45 days to allow a person to gather background information prior to commenting. (See Letters 6E, 34D.)

RESPONSE: As previously noted, the various steps necessary in the annual planning cycle leave little room for additional review time. The State therefore declines to extend the time allowed for public comment beyond the customary 30 day period currently contained in the Plan. The public will actually have more than 30 days to review the proposed projects and proposed work plan because the pre-draft Restoration Work Plan will be available to any member of the public upon request. Moreover, as stated in the Plan, the State will have an electronic mailing address and will be responsive to inquiries from members of the public by e-mail, regular mail, or phone to provide assistance to allow for public review and comment.

COMMENT: TU comments that it appreciates that the plan invites public comment on annual plans. (See Letter 7C.)

RESPONSE: The State appreciates TU's comment.

COMMENT: MWF comments that it is concerned with the bureaucratic nature of the project selection process and feels that the process is too focused on state agency involvement at the expense of meaningful public involvement. (See Letter 8F.)

RESPONSE: The State recovered damages for injury to natural resources held in trust for the people of Montana pursuant to CERCLA. The expenditure of the damages recovered will be administered by the State's natural resource Trustee, the Governor, acting through administrative agencies of the State, and the NRDP in particular. The restoration project selection process, therefore, is subject to state agency, or "bureaucratic," involvement. The other so-called "bureaucratic" requirements in the selection process were imposed by the United States and the Tribes in the Consent Decrees. Through the Plan's restoration decision-making process, however, the State has sought to ensure that all viewpoints are considered to the extent possible to promote reasoned and responsible deliberations. A wide variety of persons and entities may apply for grants of restoration funds for restoration projects which they are responsible for designing. In addition, the decision making process calls for the input of the Advisory Council, the public and others throughout the annual cycle. Therefore, the State believes 
that the process is appropriately balanced between state agency involvement and public involvement.

COMMENT: Powell County comments, relative to page 32, that public participation should be optimized, rather than maximized, and that a whole group of people probably is not going to have an opportunity to participate through the Internet. (See Letter 12G.)

RESPONSE: Powell County's comment is well taken. While the State agrees that public participation should be optimized, the State feels that the term "maximized" does not exclude this concept. The State is also aware that a number of people may not have an opportunity to participate through the Internet. Internet participation will be one of several avenues that members of the public may utilize to participate and register comments on proposed restoration work plans.

COMMENT: Powell County comments, relative to page 32 , that failure to mention landowners, on whose land restoration projects will undoubtedly occur, is not a smart thing to do. (See Letter 12E.)

RESPONSE: The State is puzzled by Powell County's comment in that the State did not intend to exclude any members of the public from participating in the restoration decision-making process. The State recognizes that specific comment and consent from landowners may be required to implement some restoration projects. Securing comment on specific projects and consent from landowners, however, is beyond the scope of this Plan and must await the proposal of specific projects.

COMMENT: Robert E. Benson comments that from the government involvement shown in Chapter 3, Figure 2, there is little real chance for the general public to be involved other than to comment on decisions already made. (See Letter 29D.)

RESPONSE: The State disagrees with Mr. Benson that there is little real chance for the general public to be involved. As stated previously, the restoration decisionmaking process incorporates public input and comment at various stages throughout. Through the Advisory Council, the formal public comment period, the availability of draft work plans, and the Stage 2 Criterion "Public Support" evaluation, members of the public can make their views known to the State during all phases of the process.

Additionally, Mr. Benson's comment assumes that public comment taken during the formal public comment period will not be seriously regarded. This is not an accurate perception because the State has and will continue to seriously consider comments received from the public.

CATEGORY 14: Emphasis on Clark Fork River. The State received one comment from Fritz Daily regarding the emphasis of the Plan. (See Letter 35D.) Mr. Daily 
comments that most of the emphasis on the settlement now seems to be on restoration of the Clark Fork River while only $13 \%$ of the original claim was for this area. The communities of Butte and Anaconda are entitled to a major portion of the restoration money spent directly on restoration projects in their communities.

RESPONSE: The State disagrees that most of the emphasis of the Plan is on the Clark Fork River, as opposed to the natural resources of other injured areas for which the State sought, or seeks, damages. As set forth in previous responses, the settlement of the State's natural resource damage claims was recovered on behalf of the people of the State of Montana, and no individual community is entitled to an exclusive share of the restoration money. In fact, the State's compensable damage claim, as asserted in the lawsuit, was based in significant part on the value of the lost uses of the injured resources of citizens residing throughout Montana. The State also observes that closer to one-third of its $\$ 765$ million claim in Montana v. ARCO related to the Clark Fork River between Milltown and Warm Springs. The State realizes, however, that restoration of the injured natural resources will result in the expenditure of funds on restoration projects in the communities of Butte and Anaconda, as well as in other communities and areas of the UCFRB.

CATEGORY 15: Public Access Issues. The State received 5 comments from 5 persons or entities regarding public access issues in the plan. These comments are as follows.

COMMENT: The Steering Committee comments that public access to private land should not be a requirement for project funding. (Letter 5D.)

RESPONSE: The General Policy Criteria in the current draft do not require public access to private land for project funding. There may, however, be certain projects undertaken on private land for the restoration of public services which may necessarily include a consideration of the public's ability to have access to the restored service.

COMMENT: MACD comments regarding land acquisition projects that public access should not be a part of the ranking criteria for these projects because small stream restoration projects on private land would benefit the landowner and the public, but the project should not have a lower funding priority because it doesn't involve public access. (Letter 4E.)

RESPONSE: As a general rule, the acquisition of land as part of a restoration project would be undertaken for the purpose of replacing an injured resource and/or its services. If restoration funds are to be used to replace public services, then public access to those services would be essential. If, on the other hand, actual restoration is to occur on private land for a public benefit downstream, for example, public access to the restoration site itself would not necessarily need to be a component of the project. 
COMMENT: The Advisory Council comments that public access should be a requirement for all fee-title, land-purchase projects and public benefit should be a requirement for all projects. (Letter $6 \mathrm{G}$.)

RESPONSE: The current draft of the Plan states that public access issues will be considered in decisions about land acquisition. When fee-title is being acquired, it is most likely that the State will require public access.

COMMENT: MWF comments that public access needs to be given higher priority in the criteria for project selection; some form of public access should be a threshold requirement for all types of projects, not just land acquisitions. (Letter $8 \mathrm{C}$.)

RESPONSE: Currently the Plan requires that the evaluation of projects involving land acquisition (or interests in land such as conservation easements) must consider whether public access is provided. The Plan contemplates that where there is a public benefit to be gained from restoring resources or their services, access to the restored resources or services will be considered. However, not all restoration activities will necessarily require on-site access in order to provide a measurable public benefit.

COMMENT: BSB comments that "Public Access" should receive greater emphasis to promote public access through land acquisition, and not just for publicly owned lands. (Letter 19FF.)

RESPONSE: BSB's comment contemplates that acquisition of lands could be utilized as a mechanism by which public access to lands already owned by the State, or others, could be secured. The State agrees with BSB that this mechanism could be utilized as a replacement or acquisition alternative related to services lost as a result of natural resource injury and has already highlighted the point in the Plan. Page 43 of Chapter 5 includes the following example of a replacement or acquisition action: "Thus, in a situation where recreational fishing opportunities on a mainstem river are lost, acquiring riparian land and access points along a relatively unimpaired tributary would return a measure of lost recreational fishing opportunities."

CATEGORY 16: Restoration Fund Management. The State received 4 comments from 3 persons or entities regarding the general management of the UCFRB Restoration Fund, as follows:

COMMENT: MEIC recommends that the NRDP funds be placed in a trust in which the principle remains inviolate and only the interest is spent, thus maximizing the amount of restoration that can be completed on the river. (Letter 10D.) Brian Holland similarly asks whether the principal and interest on the fund will be made available for projects, or just the interest. (Letter 27E.) 
RESPONSE: On June 9, 1999 the UCFRB Advisory Council adopted some "Recommended Fund Management Policies" which the Council's Chairman subsequently transmitted, by letter, to the Trustee, Governor Racicot. In a letter dated July 1, 1999 to the Chairman of the Council, the Governor indicated his general agreement with most of the recommendations of the Advisory Council. One of the policies which the Governor generally agrees upon is as follows: The nominal principal balance of $\$ 118$ million in the UCFRB Restoration Fund should be maintained over a long term, with the understanding that this principal could be used to fund significant or time critical projects if agreed upon by the Trustee at a later time. This remains the policy of the Trustee; thus, only interest earned on the principle in the coming years will be expended on restoration unless the Trustee finds that it is appropriate to invade the principle to fund significant or time critical projects. It should be noted, however, the current Trustee and future Trustees of the Restoration Fund have a right to revise this policy if they deem such a revision appropriate.

COMMENT: Brian Holland asks how the fund is managed by the State Board of Investments.

RESPONSE: The Restoration Fund is managed under a broad investment policy by the Montana Board of Investments governed generally by the "prudent expert principle." More specifically, the objectives of the investment policy include maximizing the total rate of return through a diversified portfolio of fixed income assets, providing current income for restoration expenditures and administration, and assuring an average rate of risk. A majority of the funds are invested in the Trust Funds Bond Pool (TFBP). (Letter 27D.)

COMMENT: Bill Janecke asks who controls funds prior to expenditures and who retains interest from granted amounts prior to expenditure.

RESPONSE: All funds are invested by the Montana Board of Investment and all interest earned is retained by the State in the Restoration Fund for restoration purposes. The NRDP, upon the approval of the Trustee given through the Restoration Trustee Council, has authority to expend the funds for restoration purposes on behalf of the State. As for interest earned on granted amounts prior to expenditure, this should not be an issue because the State intends to pay for most restoration projects on an invoice basis for work that has already been performed. In any case where an applicant earns interest on a granted amount prior to expenditure, that interest is to be credited to the Restoration Fund.

CATEGORY 17: Project Implementation. The State received 5 comments from 3 persons or entities related to project implementation. These comments are listed separately. 
COMMENT: MACD comments that the issue of maintenance of projects, such as costs for weed management, grazing systems, and fencing, is not addressed. MACD asks what party will be responsible for such costs, for how long, and will this issue be addressed through the application process. (See Letter 4D.)

RESPONSE: Weed management, grazing systems, and fencing may be important measures to maximize the potential recovery of the resources addressed through proposed projects. Whether as integral components, or project maintenance and follow up, the State expects that these items would be included as a part of any complete project application for which such measures are necessary to ensure the success of the project. The application form will require submission of a comprehensive scope of work in which such issues may be addressed. Cost responsibility will be considered on a case-by-case basis.

COMMENT: BSB comments that on Chapter 3, page 33, the threat of termination is unnecessary and overstated and that there is standard contract language to deal with implementation failures. (See Letter 19U.)

RESPONSE: The Plan states: "If the accounting reveals an impropriety, the State has the right to terminate project funding." The State disagrees with BSB's characterization of this as a threat. The State will have the authority to terminate project funding if it finds that the project is not consistent with the original proposal or for other significant reasons. Sound fund management dictates that the State should exercise this authority in appropriate circumstances. Contractual provisions in the grants will set forth the grounds upon which this authority may be exercised.

COMMENT: Bill Janecke comments on Chapter 3, page 28, and questions if a grant is awarded to a non-government organization will they be required to follow the State's procurement procedures and contracting laws, and if not, what procurement and contracting practices might be imposed and how will this information be made available. (See Letter 34A.)

RESPONSE: Non-government grantees will be required to follow the State's procurement procedures, and, depending on the circumstances, may be required to follow the State's contracting laws. This will be assessed on a project-by-project basis, and incorporated in each grant's contractual provisions.

COMMENT: Bill Janecke comments on Chapter 5, page 45, asking what will be the documentation requirements on all projects and will quarterly progress or annual progress reports be required. (See Letter 34E.) 
RESPONSE: Documentation requirements will be addressed on a project-byproject basis. The State expects grant recipients to provide full documentation and progress reports where necessary, and as set forth in the draft plan on page 33, this could occur in a number of ways, depending on the project. The NRDP could be responsible for oversight or for arranging for oversight; also the applicant could be required to arrange for oversight and/or progress reports.

COMMENT: Bill Janecke comments on Chapter 3, page 33, asking what detail will be required for the final designs submitted to NRDP, especially on the nonengineered projects and will NRDP be required to review and return the final designs within the 30-day pre-construction period. (See Letter 34L.)

RESPONSE: The detail required for the final designs submitted to NRDP will be described in the application form. This includes a scope of work, project budget, and supporting technical documentation.

CATEGORY 18: Application Form. The State received 4 comments from 4 persons or entities stating that an application form should be prepared which shall be used by all project applicants. (See Letters 5J; 6F; 190; 34B.) Two of the comments requested that a shorter application form be available to persons applying for $\$ 5,000.00$ or less in funding. Additionally, Bill Janecke comments on Chapter 3, page 29, asking will each applicant for NRD funds be required to state their qualifications as a condition for consideration for NRD funds and, if not, when will qualifications of applicants be sought and will the qualifications be a matter of public record?

RESPONSE: The State is preparing an application form to be used by all project applicants, and the State anticipates preparing an abbreviated form for persons or entities applying for $\$ 10,000.00$ or less in funding. Applicants will be required to state their qualifications as a part of the application process, present a scope of work, a detailed project budget, and statements addressing the criteria for decision making. Application responses will be public documents.

CATEGORY 19: Projects in Areas Where No ROD Has Been Issued. The State received 3 comments from 3 persons or entities regarding the allocation of settlement money to areas of the UCFRB for which a ROD has been issued. (See Letters $4 \mathrm{C}$; 9F; 27C.) Each of the comments suggests that the State take into account whether a ROD has been issued for an area in which a restoration project is proposed, and that the State should consider funding only projects located in areas for which a ROD has been issued.

RESPONSE: This comment highlights a difficulty that will be faced in funding restoration project proposals in areas for which a ROD has not yet been issued. Without the ROD, it is more difficult to coordinate restoration with proposed remedial action. This is not to say that restoration projects will not be funded in areas for which a ROD 
has not been issued. In some cases, it may be possible to predict remedial actions with a sufficient degree of confidence to consider whether and to what extent the proposed restoration project will not interfere or may be coordinated with the anticipated remedy. This consideration will occur during the evaluation of the Stage 1 criterion, Results of Response Actions

CATEGORY 20: Administrative Expenses. The State received 4 comments from 3 persons or entities requesting that administrative expenses associated with the NRD Program and the evaluation of project proposals be specifically limited. (See Letters 5G; $19 \mathrm{HH}, \mathrm{LL} ; 22 \mathrm{~F}$.) BSB comments that the statement of "The State will endeavor to minimize these expenses" has little credibility unless there is a willingness to impose a cap on such expenses and release detailed expense reports on a regular basis.

RESPONSE: The State repeats that it will, in good faith, endeavor to minimize administrative expenses in order to maximize the amount of money spent on actual restoration of injured resources. The State would be ill-advised, however, to impose such a cap without experience in administering such an unprecedented fund. The arbitrary imposition of a cap on administrative expenses will not produce a better administered fund. The comment that the plan should provide for the release of detailed expense reports on a regular basis is well taken, and the State accounted for this issue in the proposed plan. The State considered that such expense reports would be included in an annual status report, as set forth on page 34 of the Plan (the State prepares monthly expense reports for most state agencies, including the NRDP). Additionally, should it become evident that administrative expenses are excessive, a cap on administrative expenses based on experience and the reality of administering the Fund may be imposed for future years.

CATEGORY 21: Upfront Funding. The State received 3 comments from 3 persons or entities requesting that in cases in which project applicants are unable to finance a project themselves, upfront funding, rather than reimbursement, should be provided. (See Letters 5F; 8D; 19X.)

RESPONSE: Sound fund management dictates that the State pay only for approved restoration work. To insure that funds are expended only for approved items or work, the State will customarily utilize a reimbursement procedure for approved expenditures. There may be cases in which upfront funding can be provided to successful applicants for certain expenditures. This will have to be approached on a caseby-case basis.

CATEGORY 22. Project Development Grants. The State received 3 comments from 3 persons or entities related to the availability of project development grants. 
COMMENT: The Steering Committee comments that the statement on page 29 that applicants may submit an application for project development funding should be changed to read that applicants may apply for a project planning grant, and that such grants should not be awarded for speculative projects, but must demonstrate an idea for a project that is likely to succeed. (See Letter $5 \mathrm{H}$.)

RESPONSE: The State agrees that project planning grants should not be awarded for speculative projects, and that a project development grant proposal must demonstrate an idea for a project that is likely to succeed. The statement on page 29 will be revised to more clearly state how decisions about whether to approve such grants will be made. The merits of project planning grants will be evaluated and weighed in light of the decisionmaking criteria set forth in Chapter 4 to the extent it is applicable. Just as the State will utilize the criteria to make sure that UCFRB Restoration Fund money is not disbursed for projects that are not likely to succeed, the State will not disburse project planning grants for speculative projects that are not likely to succeed.

COMMENT: BSB comments that funding project development grants is not in the best interest of ensuring restoration dollars are spent on restoration. (See Letter 19Q.)

RESPONSE: The State appreciates BSB's concern that the amount of restoration funds devoted to actual restoration actions be maximized. Careful planning and integration with ongoing and planned remedial actions is also a necessary prerequisite to maximize the actual restoration of injured resources through expenditure of the UCFRB Restoration Fund. To promote this policy, and promote the development of project proposals from persons or entities who may have sound restoration project ideas but may not have funds available to develop those ideas, some funds should be available to assist in the development of project proposals.

COMMENT: Bill Janecke questions whether the time frame and application process would be the same for project development grants as it is for shorter duration work and, if yes, can a continuous funding cycle be established for project development grants that fall below a certain dollar threshold amount. (See Letter 34C.)

RESPONSE: The State will revise the Plan as it relates to project development grants and will establish a separate application process for such grants based upon continuous funding cycle.

CATEGORY 23: Chapter 4 Terminology. The State received 3 comments from 2 persons or entities requesting specific changes be made to terminology utilized in Chapter 4. (See Letters 19Z,AA; 29G.)

COMMENT: BSB comments on Chapter 4, page 35, "technologically infeasible impossible" appears to have an extra word. (See Letter 19Z.) 
RESPONSE: The State agrees with this comment and will correct this error in the text.

COMMENT: BSB comments on Chapter 4, page 36, the "Results of Response Action" criterion appears to have been mischaracterized and the State should substitute the word "consistency" for "results." (See Letter 19AA.)

RESPONSE: The State disagrees with BSB that this criterion has been mischaracterized. Consistency with response actions (which will not always be necessary in order to approve a restoration project) is a conclusion that the State must reach independent of the opinion of a project applicant. Furthermore, this language is taken from DOI's NRD regulations. Knowledge of the results or anticipated results of response action will allow the State to conduct restoration planning on an integrated basis.

COMMENT: Robert Benson comments on Chapter 4, page 37, reference to recovery period is not defined. (See Letter 29G.)

RESPONSE: The terms "recovery period," and "natural recovery" as utilized in this section refer to the period of time required for an injured natural resource to recover to baseline, or pre-injury, condition. The State appreciates Mr. Benson's comment and will include the definition in the text of the Plan.

CATEGORY 24: SSTOU Remediation. The State received 3 comments from 2 persons or entities specifically related to the SSTOU remedy.

COMMENT: GSD comments that the funding for the SSTOU remedy should be spent on this site and that any excess monies in the SSTOU fund should be prioritized for natural resource restoration projects within or related to the SSTOU site as opposed to projects within the Basin in general. (See Letter 21E.)

RESPONSE: $\$ 80$ million, plus interest accrued thereon, was set aside in the State and SSTOU consent decrees, and these documents require that this money be utilized to implement the SSTOU remedy. The State shares GSD's hope that this remedy may be implemented for less than $\$ 80$ million plus interest. The consent decrees require that should the SSTOU remedy implementation cost less than $\$ 80$ million plus accrued interest, the excess money shall be returned to the UCFRB Restoration Fund where it will be available to fund restoration projects in the SSTOU, as well as in other areas of the UCFRB. Furthermore, it is possible that the remedy will cost more than $\$ 80$ million, plus interest, in which case it is also possible that the cost overrun, or portion of it, will come out of the Restoration Fund. (See Plan at p. 9.) 
COMMENT: GSD comments that a sentence on page 8, "Remedy implementation along Silver Bow Creek is expected to cost approximately $\$ 80$ million plus interest accruing thereon" be deleted or rephrased to reflect the GSD belief that the final cost of cleanup should be less than this estimate. (See Letter 21D.)

RESPONSE: The $\$ 80$ million plus interest estimate for SSTOU remedy implementation is based on DEQ and EPA planning and is what the State considers to be the most accurate and responsible estimate for the cost of this cleanup.

COMMENT: Robert E. Benson comments that on page 3, remedial response action is defined as "achieving a permanent solution" but page 16 states that the SBC remedy may result in significant injury and that this cannot be a remedy action as defined. (See Letter 29B.)

RESPONSE: This comment gets at the distinction between "remediation" and "restoration." Although remedial actions may sometimes restore, or partially restore, injured natural resources, they are not intended to restore injured natural resources to their baseline, or pre-injury, conditions. The terminology "achieve a permanent solution" is used to describe what a remedial action is intended to achieve in order to protect human health and the environment from further degradation; achieving a "permanent solution," however, does not necessarily equate with restoration of natural resources to baseline. In the case of Silver Bow Creek, the State believes that while the remedial action will achieve a permanent solution in that it will preclude any further degradation of human health or the environment and will partially restore natural resources, it will not restore the resources at the site to baseline.

CATEGORY 25: Funding Normal Government Function. The State received 2 comments from 2 persons or entities regarding the normal government function criterion on page 40 of the Plan. (See Letters $7 \mathrm{~L} ; 12 \mathrm{~L}$.) Powell County comments that it is in favor of the prospect that agencies will not be funded for what is prescribed as their normal functions. TU comments that the plan needs specific criteria clarifying that NRD funding will not be used to fund normal and existing obligations of government, nor should NRD funds be used for infrastructure that is a normal obligation of local government and taxpayers. TU further comments that if professional review by NRD Program scientists and others indicates that upgrades of treatment systems beyond compliance levels are needed to advance restoration of injured resources, requests for NRD funding could be considered.

RESPONSE: As currently written, the "Normal Agency Functions" criterion relates only to monitoring or research criteria. The State will revise this criterion so that it will be applicable to all government proposed projects. While the State does not intend that the Restoration Fund be utilized for normal agency functions and funding, governmental agencies may be able to utilize matching funds from other sources 
to leverage the recovered natural resource damages. Thus, State agrees with TU and Powell County in this regard; restoration dollars may be utilized to augment funds normally available to government agencies if such cost sharing would accomplish restoration of resources that would not otherwise occur through normal agency function. This will also be clarified in the text of the Plan.

The State agrees with TU that the Restoration Fund should not be used for infrastructure that is a normal obligation of local government and taxpayers. Categorical exclusion of infrastructure improvements as restoration projects, however, fails to recognize the extensive injury to natural resources within and surrounding the communities of the UCFRB. Therefore, the term "infrastructure improvements" may not be synonymous with "normal obligation of local government and taxpayers." The replacement of services that would have been provided by these resources in the absence of injury could involve expenditures that exceed the normal obligation of local governments and taxpayers, when compared to Montana communities unaffected by hazardous waste. For these reasons the State cannot categorically exclude infrastructure improvements as qualified restoration projects, including improvements of treatment systems to achieve compliance levels, to use TU's example, when such improvements involve expenditures that exceed what would be considered "normal" due to natural resource injuries in and around the communities of the UCFRB.

CATEGORY 26: Multiple Year Grants. The State received two comments from Bill Janecke related to multiple year grant applications. (See Letter 34F,G.) Mr. Janecke asks whether grant applications may be submitted for multiple year grants, how much time the applicant has to expend grant amounts, and will successful applicants be required to expend granted dollars within the granting year.

RESPONSE: It may be that more than one year, or one field season, is required to complete some proposed projects. In recognition of this possibility, the State has not placed limits on multiple year grants or time to expend grant amounts in the plan. The State reserves the right to generally address these issues in the future, and expects in the first funding cycle to address them on a case-by-case basis.

CATEGORY 27: Opposition to the Plan. The State received two comments from Fritz Daily stating his opposition to the plan. (See Letters 35A; 36A.)

RESPONSE: Mr. Daily's opposition to the Plan is noted; Mr. Daily's comments explaining why he opposes the Plan are responded to elsewhere in this document.

CATEGORY 28: MEPA Compliance. The State received one comment from Bill Janecke about compliance with the Montana Environmental Policy Act ("MEPA"). (See Letter 34I.) Mr. Janecke asks how MEPA requirements will be met, and will all successful applicants be required to complete EA's or EIS's. 
RESPONSE: In conjunction with the issuance of the yearly work plan, the State will meet MEPA requirements by conducting an appropriate form of environmental review, or the "functional equivalent" of a MEPA review, based on the significance of the potential impacts of the funded projects. In conducting that review, the State may require applicants to provide the State with information of the nature required for preparation of an EA or EIS.

CATEGORY 29: Montana v. ARCO Settlement. The State received a comment from Robert Benson relating to the terms of the Montana v. ARCO settlement and not specifically directed at the Plan itself. Mr. Benson comments that he does not understand how compensable damages for the CFROU and Milltown can be included since the $\mathrm{RI} / \mathrm{FS}$ and ROD have not been issued for those sites, and we don't know the cost of actions that may be needed for restoration in those units. (See Letter 29A.)

RESPONSE: Compensable value is the amount of money required to compensate the public for the loss in services provided by the injured resources between the time of the discharge or release and the time the resources and the services those resources provided are fully returned to their baseline condition. The State released its compensable value damages claim, in its entirety, in consideration for the Montana v. ARCO settlement. To determine its compensable value and restoration damages claims relating to operable units for which a ROD had not been issued, the State, in consultation with the EPA, estimated the outcome of remedial action at each OU in order to determine the residual natural resource damages and recovery period, from which compensable value damages could be calculated. 


\section{APPENDIX}

\section{Public Comment Letters}



List of Comment Letters

\begin{tabular}{|c|c|c|c|}
\hline Letter No. & Organization & Author & Date \\
\hline 1. & $\begin{array}{l}\text { US Environmental Protection } \\
\text { Agency (EPA) }\end{array}$ & John Wardell & October 15,1999 \\
\hline 2. & $\begin{array}{l}\text { US Dept. of the Interior, } \\
\text { National Park Service (DOI) }\end{array}$ & Phillip Tourangeau & October 15, 1999 \\
\hline 3. & $\begin{array}{l}\text { The Confederated Salish and } \\
\text { Kootenai Tribes (CSKT) }\end{array}$ & D. Fred Matt & October 15,1999 \\
\hline 4. & $\begin{array}{l}\text { Montana Association of } \\
\text { Conservation Districts } \\
\text { (MACD) }\end{array}$ & Mike Vollesky & October 8,1999 \\
\hline 5. & $\begin{array}{l}\text { Upper Clark Fork River Basin } \\
\text { (UCFRB) Steering Committee }\end{array}$ & Gerald Mueller & October 11,1999 \\
\hline 6. & $\begin{array}{l}\text { UCFRB Remediation and } \\
\text { Restoration Advisory Council }\end{array}$ & Sally Johnson & October 14,1999 \\
\hline 7. & Trout Unlimited Montana (TU) & Bruce Farling & October 12,1999 \\
\hline 8. & $\begin{array}{l}\text { Montana Wildlife Federation } \\
\text { (MWF) }\end{array}$ & Dave Dittloff & October 15, 1999 \\
\hline 9. & $\begin{array}{l}\text { Clark Fork Pend Oreille } \\
\text { Coalition (CFC) }\end{array}$ & Geoffrey Smith & October 14,1999 \\
\hline 10. & $\begin{array}{l}\text { Montana Environmental } \\
\text { Information Center (MEIC) }\end{array}$ & Bonnie Gestring & October 15,1999 \\
\hline 11. & $\begin{array}{l}\text { Missoula Water Quality } \\
\text { Advisory Council (MWQAC) }\end{array}$ & Marge Hulburt & October 13, 1999 \\
\hline 12. & $\begin{array}{l}\text { County of Powell, Deer Lodge } \\
\text { Montana }\end{array}$ & Ron Hanson & October 15, 1999 \\
\hline 13. & $\begin{array}{l}\text { Anaconda-Deer Lodge County } \\
\text { (ADL) }\end{array}$ & Carl Stetzner & October 8,1999 \\
\hline 14. & Anaconda-Deer Lodge County & James M. Manning & October 14,1999 \\
\hline 15. & $\begin{array}{l}\text { Anaconda Local Development } \\
\text { Corporation (ADLC) }\end{array}$ & Richard Campbell & October 11, 1999 \\
\hline 16. & $\begin{array}{l}\text { Anaconda Local Development } \\
\text { Corporation }\end{array}$ & James H. Davison & October 11, 1999 \\
\hline 17. & Arrowhead Foundation & William F. Hickey & September 27, 1999 \\
\hline 18. & Arrowhead Foundation & Natalie Fitzpatrick & October 7, 1999 \\
\hline 19. & $\begin{array}{l}\text { Butte-Silver Bow, Office of } \\
\text { Council of Commissioners } \\
\text { (BSB) }\end{array}$ & Ed Heard & October 14,1999 \\
\hline 20. & $\begin{array}{l}\text { Butte Local Development } \\
\text { Corporation (BLDC) }\end{array}$ & Evan Barrett & October 14,1999 \\
\hline 21. & $\begin{array}{l}\text { Greenway Service District } \\
\text { (GSD) }\end{array}$ & Meg Hickey & October 14, 1999 \\
\hline
\end{tabular}





\begin{tabular}{|c|l|l|l|}
\hline Letter No. & \multicolumn{1}{|c|}{ Organization } & \multicolumn{1}{c|}{ Author } & \multicolumn{1}{c|}{ Date } \\
\hline 22. & $\begin{array}{l}\text { Project Green Steering } \\
\text { Committee (PGSC) }\end{array}$ & Robbie Taylor & October 12,1999 \\
\hline 23. & Project Green of Montana, Inc. & Rick Griffith & October 14, 1999 \\
\hline 24. & $\begin{array}{l}\text { Granite Mountain Bank } \\
\text { (GMB) }\end{array}$ & Jerry Sullivan & September 24, 1999 \\
\hline 25. & St. James Community Hospital & Robert D. Rodgers & October 14, 1999 \\
\hline 26. & & Jim Smitham & October 7, 1999 \\
\hline 27. & & Brian Holland & October 15, 1999 \\
\hline 28. & & Robert Francisco & October 4, 1999 \\
\hline 29. & & Robert E. Benson & October 4, 1999 \\
\hline 30. & & $\begin{array}{l}\text { Margie Smith to Jim } \\
\text { Flynn }\end{array}$ & October 13, 1999 \\
\hline 31. & & Vicki Watson & October 15, 1999 \\
\hline 32. & & Beverly Dupree & October 15, 1999 \\
\hline 33. & & $\begin{array}{l}\text { Ole Ueland to Mike } \\
\text { McLane, DNRC }\end{array}$ & September 29, 1999 \\
\hline 34. & & Bill Janecke & October 14, 1999 \\
\hline 35. & & $\begin{array}{l}\text { Fritz Daily to Joe } \\
\text { Mazurek }\end{array}$ & September 8, 1999 \\
\hline 36. & & $\begin{array}{l}\text { Fritz Daily to Joe } \\
\text { Mazurek }\end{array}$ & October 8, 1999 \\
\hline
\end{tabular}




\section{UNITED STATES ENVIRONMENTAL PROTECTION AGENCY \\ REGION 8 \\ $99918^{\text {TH }}$ STREET - SUITE 500 \\ DENVER. CO $80202-2466$}

Ref: $8 \mathrm{MO}$

October 15, 1999

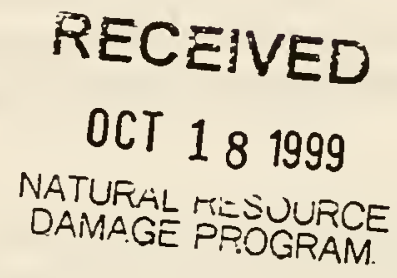

Robert L. Collins, Supervisor

Natural Resource Damage Litigation Program

State of Montana

Department of Justice

Old Livestock Building

P.O. Box 201425

Helena, Montana 59620-1425

RE: EPA comments on the Draft Upper Clark Fork River Basin Restoration Plan Procedures and Criteria - September, 1999

Dear Mr. Collins:

The Environmental Protection Agency has reviewed the State of Montana's draft restoration plan, and has the following comments.

First of all, congratulations to the State on the settlement which provides the funding for

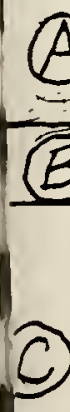
the plan's activities. The restoration component of the overall cleanup of the Upper Clark Fork Basin is important and noteworthy. EPA looks forward to working with the State and other trustees on these matters, to ensure a coordinated and effective overall cleanup for the Basin.

My comments are divided into two pars. The first part addresses important factual issues in the description of the planned or selected remedies discussed in Chapter 2 of the draft plan. EPA believes it is important that the planned or selected remedies be fully described and understood by parties using the plan, and requests that the comments on these descriptions be incorporated. If you wish further information about any of these description comments, please contact my staff directly.

The second part of my comments addresses the procedures, criteria, and suggested eligible projects used by the State in authorizing restoration projects. The interaction between response measures selected and implemented by EPA and restoration measures selected and implemented by natural resource damage trustees is complicated. For both programs to spend money wisely and efficiently will require coordination and consultation. Yet, the draft plan outlines no role for 
EPA in the evaluation process. My comments address EPA's role in evaluating projects and the role of the selection criteria as it pertains to EPA's planned or selected response actions, to ensure that this coordination and consultation occurs. EPA can and should play a constructive role in the process, and my comments offer a reasonable method for doing that.

If you wish to discuss these comments, please contact me at 406 441-1125. Particularly on the issues regarding process involvement by EPA, further discussion may be appropriate. We look forward to the final plan and continued constructive consultation.

Sincerely,

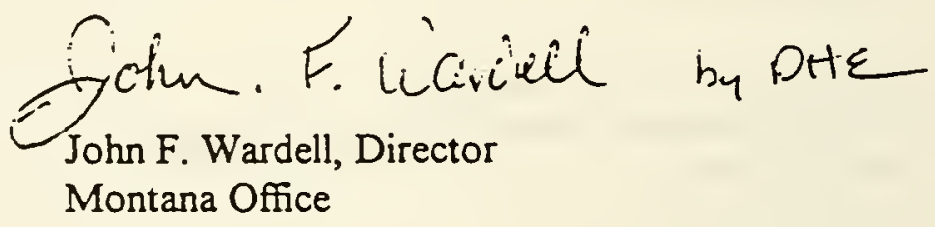

Enclosure

cc: Joe Mazurek, Attomey General

Jim Flynn, Chair, Citizen's Advisory Council

Trustee Council 


\section{Response Action Description Comments}

No comments on the Mine Flooding OU Response Action - page 11-12.

No comments on the description of the BPSOU Response Action - page $13-14$. EPA notes that the expected ROD response action described on page 14 may change depending on the conduct of the RU/FS and remedy selection process.

In the fifth builet describing the Streamside Tailings ROD and ESD, page 16, add "or remediated

$(\vec{C}$ floodplain" after the word stream. The remedial design process will examine this aspect of railbed contamination as well. In the concluding paragraph beginning with "Although", first sentence second line, insert "in-situ treated" before tailings. EPA disagrees with the conclusion that significant residual injury or environmental risk will remain after the remedy is implemented, as this would be inconsistent with the State Department of Environmental Quality's conclusion that the Streamside remedy, including the in-situ remediation aspect, is protective of the environment. This conclusion should be altered to state that a lack of immediate baseline services may result after the remedy is implemented.

No comments on the description of the Montana Pole OU remedy, page 17.

The description of the Rocker OU remedy on page 18 should be altered by inserting "Groundwater exposed during excavation of source materials was also treated to remove arsenic" after the second sentence of that paragraph. In addition, the sentence "However, the responsible party (ARCO) remains liable for additional work, if necessary, to prevent plume migration in the adjoining ground waters." should be added to the end of the paragraph.

The description of the 1998 Anaconda Regional Water Waste and Soils ROD on page 19 is accurate according to current design plans, but the sentence "EPA in consultation with the Department of Environmental Quality, reserve the ability to change the exact design for the Smelter Hill and Stucky Ridge areas based on ongoing sampling and design efforts" should be added at the end of the paragraph.

The description of the Warm Springs Ponds RODs and associated response actions on page 21 should add "The RODS required improvements in the treatment capabilities of the Pond system through lime addition and water retention control, and removed tailings in the Mill Willow Bypass".

The Chapter should contain a process description for updating the description of planned or selected response actions, as EPA's remedy selection and remedy implementation processes proceed, so that the criteria regarding response action consistency can be applied clearly through each budget cycle. 


\section{Comments on the Planning Procedures and Chapter 3}

As noted, the interaction of planned or selected response actions and selected restoration projects is an important and technically complex issue. The restoration trustee should be clearly informed of any interaction issues before he or she makes a decision to fund a restoration project. Early involvement by EPA in the evaluation process is essential to ensure an adequate airing of these issues, so that restoration money is spent wisely and efficiently.

(11)

Accordingly, we propose that EPA be added to the list of entities with whom the NRDP meets on an as-needed basis or at least once yearly, as described on page 30 , second full paragraph. We also propose that EPA be added to the list of entities to who the NRDP will provide a pre-draft plan at lest 60 days in advance of its submission to the Trustee Restoration Council (note we propose lengthening this time period from the proposed 30 day time period) ( $2 \mathrm{~d}$ bullet page 30); and adding EPA to the commenting agencies described in the $1^{\mathrm{s}}, 2 \mathrm{~d}$, and $3 \mathrm{~d}$ bullets, page 31 . If issues have not been resolved satisfactorily prior to the submission of the final recommendation on the Restoration Work Plan to the Govemor, we propose that a specific meeting with EPA and the Governor be added to the bullet list prior to the Governor making his or her decision on the Restoration Work Plan.

These coordination issues are very important to EPA. EPA has gone to great lengths to involve trustees in its decision making processes for response actions, for the important policy reasons stated above, and EPA's involvement in the restoration planning processes by the trustees, including the State, should be reciprocal. EPA's national and local expertise on feasibility and other technical issues involved with hazardous substance cleanup should be viewed as a resource for use by the State NRDP, and the procedural methods proposed above will help ensure that the necessary coordination occurs.

EPA also strongly supports the advance involvement of the other entities associated with these processes. The Advisory Council, the Department of the Interior, and the Salish and Kootenai Tribe, as well as the State agencies, all play important roles in evaluating restoration actions and ensuring adequate and coordinated restoration actions take place.

Adoption of these procedures would necessitate an accurate description of EPA's role in the cleanup process in the beginning section of Chapter 3 and the flow chart of process activities at the end of Chapter 3.

\section{Comments on the Criteria for Selection and Chapter 4}

The criteria related to consistency with planned or selected jesponse actions is an important one, from a legal and policy perspective. Consistency, meaning actions by the restoration trustees which do not disrupt planned or implemented physical actions done under response action authority, is necessary to ensure the wise and efficient expenditure of limited resources. We appreciate the State's attempt to highlight this approach through the proposed criteria on page 36 and 37 (Results of Response Actions) and page 39 (Ecosystem 
Considerations, Coordination and Integration). The page 39 criteria should be clarified to state that "actions" means response and restoration and other related actions. The page 36-37 criteria s should be expanded to emphasize that projects which can be efficiently coordinated with response projects, such that cost savings can be achieved, will be favored by the State NRDP and Governor. Expanding the criteria in this way will ensure that the coordination and consistency issues will be highlighted and seriously considered during the restoration selection processes.

\section{Comments on Types of Eligible Restoration Action and Chapter 5}

We are encouraged that the State NRDP recognizes a wide range of eligible restoration actions which are possibly eligible for funding by the State. This is particularly important in the area of aquatic and stream cleanup, where EPA believes that a wide variety of actions, complimentary to response actions (which are required by law to deal with hazardous substance, pollutant, and contaminant contamination and associated ARARs), may be appropriate for the overall environmental health of a stream. This is particularly true in the Clark Fork River, where multiple stressors are present. We look forward to a good dialogue about coordination of response and restoration actions in this area to achieve the desired end of a healthy Clark Fork River ecosystem through efforts by the public and bath programs. 



\section{United States Department of the Interior}

NATIONAL PARK SERVICE

Grant-Kobrs Ranch National Historic Site

P. O. Box 790

Deer Lodge, Montana 59722-0790

IN REPLY REFER TO:

October 15, 1999

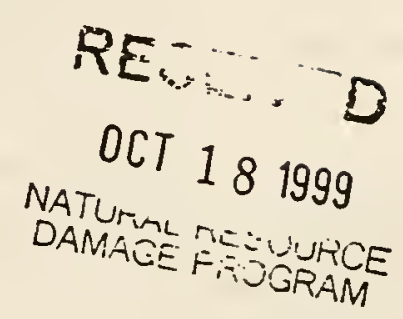

Robert Collins, Supervisor

Natural Resource Damage Program

Montana State Department of Justice

old Livestock Building

1310 East Lockey Avenue

P. O. Box 201425

Helena, MT - 59620-1425

Dear Mr. Collins:

The following comments are submitted on the DRAFT UPRER CLARK FORK RIVER BASIN RESTORATION PIAN PROCEDURES AND CRITERIA, (Draft Plan) prepared by the Natural Resource Damage Program (NRDP) and dated September 10, 1999.

These comments are submitted in the spirit of enhancing coordination and cooperation among natural resource trustees as we work through the difficult, complicated, trying, but ultimately rewarding task of restoring the Clark Fork River Basin natural resources. These comments are further directed toward the process, schematically depicted in Eigure 2 of the Draft Plan, which the State of Montana (the State) proposes to follow in its annual cycle of natural resource damage restoration planning.

As you know, the Memorandum of Agreement (MOA) between the State, the Confederated Salish and Kootenai Tribes (the Tribes), and the Department of the Interior (DOI) provides, among other things, an opportunity for the natural resource trustees (trustees) to participate in the restoration planning meetings of other trustees. In addition, the MOA provides that trustees will have an opportunity to review and comment on restoration plans of other trustees at least 30 days before the plans are submitted for formal public review, and at least 30 days before the plans are finally approved. Inspection of Figure 2 does not indicate how these MOA provisions will be accommodated by the state. Provision should be made, at a minimum, for the trustees to participate in the proposed state restoration planning process as follows: 
participate in the NRDP meetings and evaluations which will occur during the period April - June and which would be held for the purposes of conducting the activities identified in the Figure 2 box labeled Natural Resource Damage Program ("NRDP") Evaluates Applications and Prepares "Pre-Draft Restoration Work Plan".

2. Trustees should be provided an opportunity to participate in the Trustee Council and the NRDP planning meetings which will occur in september while conducting activities identified in the Figure 2 box labeled Trustee Restoration Council Considers Pre-Draft Work Plan and Directs NRDP To Prepare" "Draft Restoration Work Plan".

3. Trustees should be provided an opportunity to participate in the planning meetings by the NRDP and the Trustee Council which will take place in October and November while

(D) conducting activities identified in the Figure 2 boxes labeled NRPD Responds to Public Comment, Revises Draft Work Plan and Submits It To Trustee Council, and Trustee Council Finalizes Proposed "Restoration Work PIan" and Submits it to Governor for Approval.

4. Trustees should be provided at least a 30 day

(E) period for review and comment on the Draft Restoration Work Plan before it is released to the public in september, as shown in the Figure 2 box labeled Draft Restoration Plan Released For Public Comment.

5. Trustees should be provided at least a 30 day period for review and comment on the proposed Restoration Work Plan after it is finalized by the Trustee Council but before it is submitted to the Governor for approval in November, as shown in the Figure 2 box entitled Trustee Council Finalizes Proposed Restoration Work plan and Submits it to Governor for Approval.

Thank you very much for affording this opportunity to comment on the Draft Plan.

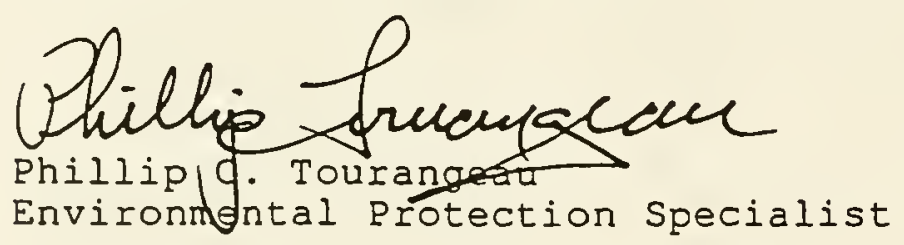

Cc: Debra Hecox, SOL

Joseph Hovenkotter, CS\&KT

Paul Meyer, BLM

Bill Olsen, FWS

Robert Stewart OEPC

Suzanne Schaeffer, USDOJ 
- Require matching funds of a certain proportion in support of project funding (with the proportional match requirement lesser for high-priority projects and higher for low-priority projects).

Such an approach is systematic in size so that the restoration planning will be comprehensive in scope and unified in its analysis of resources. Deriving project specific goals from such an approach best facilitates achieving watershed-scale goals in a cost-effective manner.

Judging Success/Adaptive Planning - There are no specific criteria identified for setting resource condition benchmarks (i.e. baseline condition to restored condition). Similarly, there are no specific methods identified for measuring restoration progress or success. Because the magnitude of the injury, this restoration initiative is without precedent. Therefore, at the Basin scale, we think it is prudent to implement an adaptive planning process. The absence of specific criteria and methods leaves us uncertain how you will assess your success in order to know how and when to adapt changes that will maximize the likelihood for success.

Trustee Participation in Planning - We are pleased to see that you have referenced the Memorandum of Agreement Among the State of Montana, Confederated Salish and Kootenai Tribes, United States Department of the Interior, Regarding Restoration, Replacement, or Acquisition of Natural Resources in the Clark Fork River Basin ("MOA")in your document. As you know, the MOA provides an opportunity for trustees to participate in other trustee restoration planning. Specifically, the MOA provides that trustees will have an opportunity to review and comment on restoration plans of other trustees at least 30 days before the plans are submitted for formal public review, and at least 30 days before the plans are finally approved. We are uncertain how you will accommodate these MOA provisions. However, within the context of the planning process presented at Figure 2, at a minimum, the Tribes (and the Department of Interior) should be provided:

(1) an opportunity to participate in the State's meetings and evaluations in completion of the planning component identified as Natural Resource Damage Program ("NRDP") Evaluates Applications and Prepares "Pre-Draft Restoration Work Plan";

(2) an opportunity to participate in the Trustee Council and the NRDLP planning meetings in completion of the planning component identified as Trustee Restoration Council Considers Pre-Draft Work Plan and Directs NRDA to Prepare "Draft Restoration Work Plan;

(3) an opportunity to participate in the Trustee Council and the NRDLP planning meetings in completion of the planning component identified as NRDA Responds to Public Comment, Revises Draft Work Plan and Submits It To Trustee Council;

(4) not less than 30 days for review and comment on the Draft Restoration Work Plan before it is released to the public as one portion of the planning component identified as Draft Restoration Plan Released For Public Review; and 
(5) not less than 30 days for review and comment on the proposed Restoration Work Plan after it is finalized by the Trustee Council but before is it submitted to the Governor within the planning component identified as Trustee Council Finalizes Proposed "Restoration Work Plan" and Submits it to Governor for Approval.

The Tribes appreciate your efforts toward acquiring our review and comment. We also appreciate your efforts in implementing such an unprecedented restoration intiative. Thank you for the opportunity to participate.

\author{
Sincerely, \\ D. Frel Matt \\ D. Fred Matt \\ Tribal Council Vice-Chairman
}





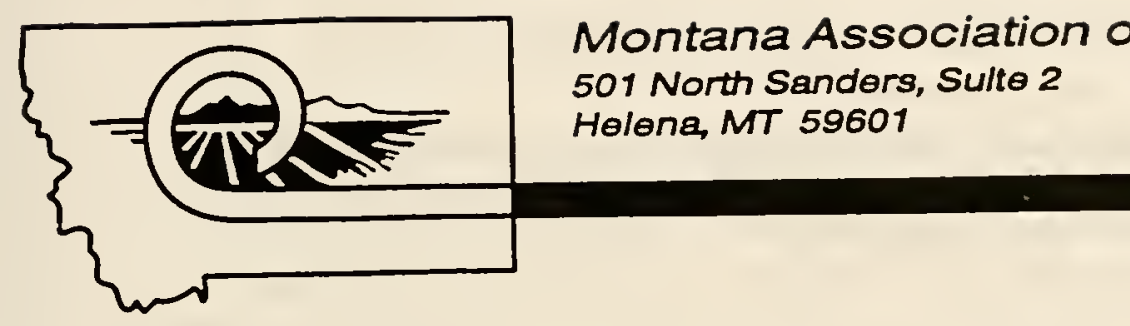

October 8, 1999

RECEIVED

OCT 151999

Rob Collins

NATUEALA NESUURCE

DAMAGE PROGRAM

Montana Department of Justice

1310 E. Lockey, Old Livestock Building

PO Box 201425

Helena, MT 59620-1425

Dear Mr. Collins:

Below are seven comments on the Draft Upper Clark Fork River Basin Restoration Plan Procedures and Criteria of September 10, 1999. I am submitting them on behalf of Deer Lodge

Valley, Granite, Mile High, Missoula, and North Powell Conservation Districts.

Comments on the Draft Upper Clark Fork River Basin Restoration Plan Procedures and

Criteria, September 10, 1999. Submitted by Deer Lodge Valley, Granite, Mile High,

Missoula, and North Powell Conservation Districts.

1) General Comment: The draft document discusses little in the way of goals. What are the expectations, after $\$ 130$ million is spent in the basin? Do we expect it to be "the way it was?" Do we expect a blue ribbon trout fishery? Is it expected that we apply $60 \%$ of the settlement to on-the-ground projects (as opposed to administrative expenses or funding for studies), or $90 \%$ ?

2) General Comment: We understand that not all resources are "restorable," and that some off-site mitigation will be necessary. However, such mitigation should take place within the Upper Clark Fork Basin only.

3) General Comment: The status of the entire ARCO settlement is unclear in relation to the $\$ 130$ million settlement designated for the Upper Clark Fork River Basin. Several

(C) segments of the river system are not yet settled with a final record of decision. Is this source appropriate for funding projects in these areas? (examples: Upper Clark Fork from Warm Springs down to the Milltown Dam and the Milltown Dam...estimated decision expected in year 2000).

4) General Comment: The issue of maintenance of project areas is not addressed. Can this

(D) funding be used for the costs of maintenance, say, for weed management, management of addressed through the application process?

5) General Comment: Land Acquisition is addressed on pages 39 and 43 . In projects involving land acquisition by the state, it follows that public access will be an important 
element in considering the project's value. However, public access should not be a part of the ranking criteria for other projects. An example would be a small stream restoration project on private land. Both the landowner and the public would realize benefits, but the project should not have a lower funding priority because it doesn't involve public access.

6) Chapter 5: General Comment. Very little emphasis and description is given for types of eligible restoration actions which address lost "Services...for the public" under Restoration Cost Damages and "economic harm suffered by the public" under Compensable Value Damages as defined on page 4 for Superfund laws establishing eligible recovery of damages. Page 4 states, "Both measures of damages, taken together, are designed to put the (F) public back in the position it would have been in had the injury not occurred." We suggest that examples of eligible restoration actions be given for lost services and economic harm to both the general public and to private individuals, especially landowners and agricultural operators. Restoration for injuries to the general public (like decreased recreational opportunities) receive due emphasis, but the restoration potential for injuries to individuals in the public sector (like damage done to livestock forage or riparian resources on private land) is not addressed.

7) Page 42, Paragraph 4: Existing language in this paragraph emphasizes the exclusion of both humans and livestock as management techniques. The following substitute language is suggested in order to emphasize use of best management practices to help the resource recover, while supporting access and benefit from the resource.

The use of best management practices. Managing natural resources through the adoption and use of best management practices can create recovery of the resource while maximizing public benefits from it. Examples include comprehensive weed management practices, revegetative practices, hunting and fishing management approaches, irrigation water management techniques, grazing management systems, and management of livestock in riparian zones.

Thank you for the opportunity to comment.

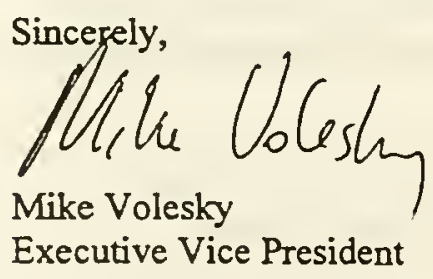




\section{Upper Clark Fork River Basin Steering Committee \\ C/O Gerald Mueller \\ 7165 Old Grant Creek Road \\ Missoula, MT 59808 \\ (406)543-0026}

October 11, 1999

Rob Collins

Supervising Assistant Attorney General

Natural Resource Damage Program

P.O. Box 2001425

Helena, MT 59620-1425

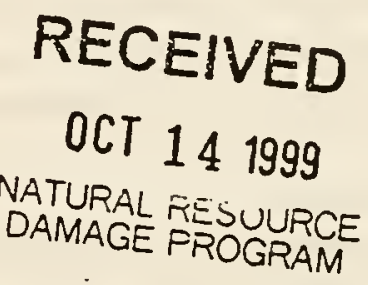

Dear Mr. Collins:

The purpose of this letter is to offer comments by the Upper Clark Fork River Basin Steering Committee (Steering Committee) on the September 10, 1999 Draft Upper Clark Fork River Basin Restoration Plan Procectures and Criteria (Draft Plan). The Steering Committee has an interest in the Draft Restoration Plan because of our mandate in state law concerning water planning and management in the Upper Clark Fork River Basin. The Steering Committee was created in 1991 pursuant to legislation passed by the 1991 Montana Legislature. In December 1994, pursuant to that same law, the Steering Committee drafted and presented to Montana's Legislature and Governor the Upper Clark Fork River Basin Water Management Plan (Water Management Plan). The goals of the Water Management Plan are twofold, first, to provide for continued planning and management of the waters of the upper Clark Fork River Basin rooted at the local level, and second, to balance all beneficial water uses in the basin.

At its most recent meeting on October 6, 1999, the Steering Committee discussed the Draft Plan, and the Steering Committee members present agreed to the following comments on it.

\section{Restoration Road Map}

Before proceeding with funding restoration projects, it is crucial to lay out a road map to guide the restoration effort. The road map should set forth a vision statement and goals as well as a process to evaluate how funded projects are achieving the vision and goals. The road map should be developed by the Upper Clark Fork Remediation and Restoration Education Advisory Council in a public process over a relatively short time period such as six months to a year.

\section{Structure of Restoration Planning Process}

According to the Draft Restoration Plan, restoration planning authority would rest in the Upper Clark Fork River Basin Trustee Restoration Council consisting of the Governor's Chief of Staff and the directors of the Departments of Environmental Quality, Fish, Wildlife and Parks, and Natural Resources and Conservation. This Council would, in tum, be advised by the Upper Clark Fork Remediation and Restoration Education Advisory Council. Given our goal of rooting planning and management at the local level, we recommend that the Trustee Restoration Council and the Upper Clark Fork Remediation and Restoration Education Advisory Council be combined. This would ensure that restoration planning authority would rest in a group including representatives of basin local governments and basin local interests (including agriculture and 
environmental/recreation organizations) as well as state agencies. We further suggest that other state departments be represented, including Agriculture, Transportation, and Commerce.

\section{Agricultural Productivity}

In discussing injuries to natural resources, the Draft Restoration Plan does not address loss of agricultural productivity due to contamination of land and water. Agriculture productivity should be a benefit pursued by the restoration road map.

\section{Public Access}

Public access to private land should not be a requirement for project funding. Requiring access is likely to result in the lack of cooperation from land owners who might otherwise welcome restoration activities on their land.

\section{Explanation of "Services"}

(E) Page 38 of the Draft Restoration Plan discusses the relationship between service loss and service should be provided to help potential project applicant's understanding of this criterion.

\section{Project Funding}

According to page 33, project funding will generally be provided after work is completed. Some potential applicants, however, may not have sufficient resources to fund a project with the expectation of reimbursement. Up-front funding and staged funding should be available for project applicants.

\section{Funding Cap}

The amount of funding available for project development, administration, and monitoring should be capped to ensure that funding is predominantly used for restoration.

\section{Project Development Funding}

Page 29 of the Draft Restoration Plan states that an applicant may submit an application for project funding. Because it is not clear what project development funding means, we suggest that this statement be changed to read that applicants may apply for a project planning grant. Such grants should not be awarded for speculative projects; to receive such a grant, an applicant must demonstrate an idea for a project that is likely to succeed.

\section{Voluntary Water Rights Acquisitions}

According to page 39 of the Draft Restoration Plan, land acquisition may be a permissible restoration activity. Along with land acquisition, acquiring water rights on a voluntary basis should also be considered.

\section{Application Form}

(T) An application form should be developed and attached to the Draft Restoration Plan in an appendix.

On behalf of the Steering Committee, I thank you for this opportunity to offer comments on the Draft Restoration Plan. Thank you also for the assistance of your staff, such as Candice West's 
participation in our October 6 meeting, in keeping the Steering Committee informed about the Natural Resource Damage Program activities.

Sincerely,

Gerald Mueler

Gerald Mueller

Facilitator

Upper Clark Fork River Basin Steering Committee 



\section{UCFRB Remodlation and Rostoration Education Advisory Councll comments and rocommended changes in NRDP Draft Rentoration Plan Procedures and Critoria}

1. The Advisory Council agreed to not make any recommendations at this time on the important issue of where the restoration office be located because it is a question that is separate from the specifics of this Draft Plan.

2. Appreciation is expressed to the NRD Program staff for noticeable

A improvements in the readablity of the Draft Restoration Plan under rovlew compared with earlier drafts.

3. If the NRD Program is going to make recommendations to the Trustee Council on whether they should fund development of a project, that decision should involve some participation whth the Advisory Council. The Council should be able to look at these proposals for projects' development costs as well as the speclfic projects themselves.

4. The decision-making process should be streamlined. We recommend the Trustee Councll be combined with the Advisory Council. The combined

(C) Advisory/Trustee Council should make its recommendations on planning documents and projects directly to the Govemor.

5. The role of the Advisory Counell is inaccurately portrayed In the Draft Plan as a group that advises the NRD Program, when, in fact, the Council's role is to advise the Governor.

6. We recommend modfying the Dratt Plan flow chart representing the annulal restoration planning cycle (Figure 2) to:

(1) delete the parallel process;

(E)

(2) increase the time period for public review and comment: and

(3) reflect the new role for the combined Advisory/Trustee Council, if implemented.

7. For small projects costing $\$ 5,000$ or less, the application for funding should be minimal.

8. Public access should be a requirement for all fee-title, land-purchase projects: public benefit should be a requirement for all projects.

9. Project funding should only be spent on projects in the Basin. 


\section{KNIGHT \&}

MASAR, PLLP

ATTORN IS IT LAW

\section{FACSIMILE TRANSMISSION SEIEET}

ROBERT M. KMIGHT

JAMES J. MnSAR

GRECORY G. SCHUI.TZ

SARA J. (SAULY) JOHNSON
300 THE FLORENCE 111 NORTH HICCONS A VENUE, 59802 P.O. BOX 8899

MissoULA, MONTANA $59807-8899$

(406) $721-5440$

1-800-T22-8957 DN MONTANA

FAX $(400) 721-8644$
DATE: $\frac{10 / 14 / 99}{\text { TIME: } 1: 30}$

ATTENTION :

FAX NUMBER:

RE :

FROM :

TRANSMITTED BY:
NUMBER OF PAGES: (including this page)

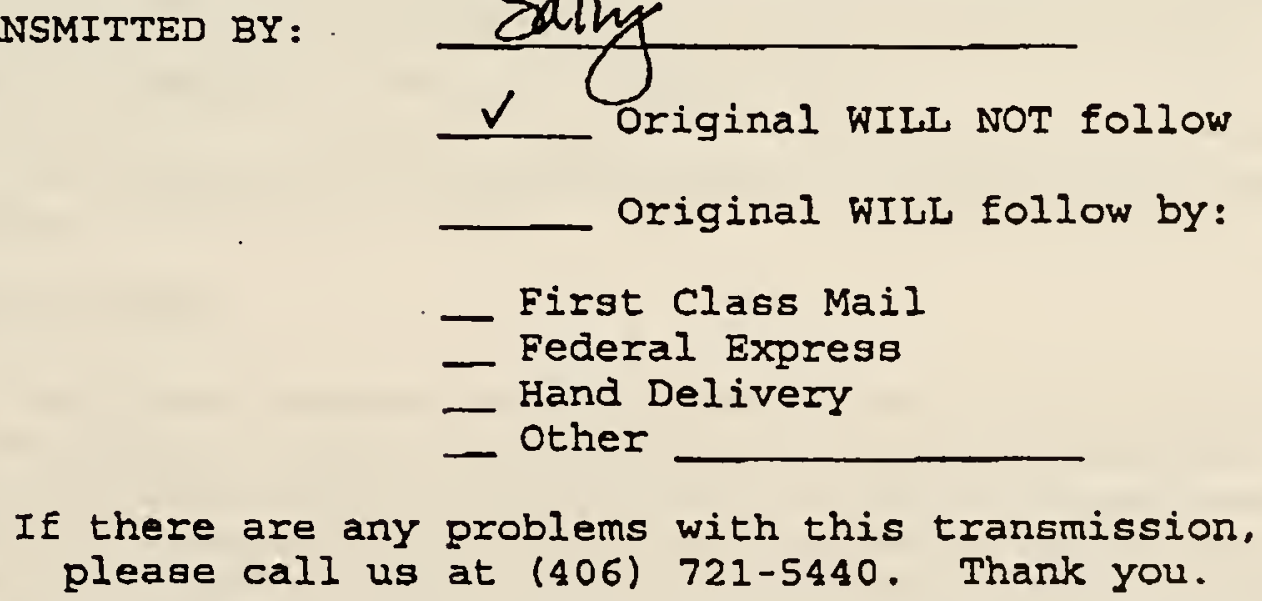

Rob Collins, Esq.

(406) $444-0236$ Comments on Restoration Plan

Sara J. (Sallv) Johnson

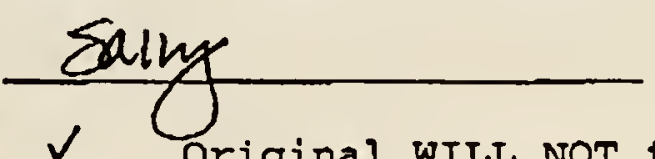

CONFMENTLALTY NOTCE: The document(s) accompanying this fax contain confidential information which is iegally privileged. The informaxion is inlended only for the use of the named recipient. If you are not the intended recipient, you are hereby norified that any disclosure, copying, distriburion or the laking of any action in reliance on the comems of this telecopied informantion except its direce delivery to the inlended recipicns is strictly prohibited. If you hove received this fax in error, please nolify us immediately by relephonc to arrange for the returu of the documenus to us. 



\section{TROIT}

12 October 1999

Rob Collins, supervisor

Natural Resource Damage Litigation Program

Montana Department of Justice

Old Livestock Building

1310 East Lockey Avenue

Helena, MT 59620
PEEE? EDD

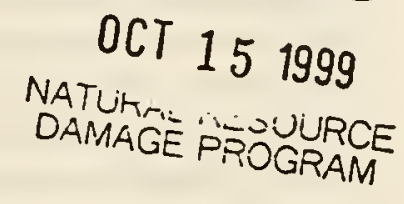

re: draft upper Clark Fork River basin restoration plan procedures and criteria

Dear Rob:

Thanks for the opportunity to comment on the draft plan that details procedures and criteria for restoring the Upper Clark Fork with the settlement Montana received in its case with Arco. We see merit in much of the plan and appreciate the NRD program's efforts in developing this draft.

Among the general elements we like in the plan are its recommendation that the NRD program have a continued role in helping implement the restoration plan. It's our view that some of the expertise developed in the NRD program could play an important role in helping ensure settlement funds are spent efficiently, effectively and for the purposes related to the original claim.

(C) We also appreciate that the plan places an emphasis on restoration projects initiated by interests outside the NRD program, and that it also invites public comment on annual plans. And fmally, we strongly believe that the suggested Phase I screening criteria are necessary for ensuring settlement finds target resources that were the subject of the claim.

The plan does have some fundamental shortcomings. The following comments attempt to address them.

\section{Goals and Objectives}

The plan has no overarching restoration objectives and goals for the basin. Instead the plan simply catalogues injured resources, which is fine for providing background. The document, however, doesn't identify specific, measurable goals that can indicate whether ample restoration, enhancement or replacement of injured resources occurs. We believe specific objectives are necessary in order to ensure restoration occurs in an orderly and efficient fashion. We also believe that identification of restoration targets doesn't necessarily have to wait until the balance of the claim is resolved, or until Superfund remedies have been finalized for all the operable units. Without objectives, restoration could become merely a collection of random and unconnected projects. Based on comments on page 28, it appears the NRD program has some sort of broader vision for restoring injured resources. The document says that "... when the NRDP believes that any specific restoration needs are not being met by projects being proposed by others, the NRDP 
with the approval of the Trustee Restoration Council, may issue requests for proposals ("RFPs") to meet these restoration needs."

The plan doesn't specify what these "restoration needs" are. We suggest the plan be amended to include basin-wide objectives for surface and groundwater, fish and wildlife, riparian and upland habitat, and so forth. We attempted to do that for aquatic resources and the services they generate in the restoration guide we published in April (Workman et al 1999). Annual work plans should identify mileposts for each objective. This would help ensure that restoration needs, rather than random proposals, drive annual planning. It might be desirable for the NRD program to break the upper basin into distinct geographic units. Annual plans could focus mainly on specific geographic areas, with the priorities based on the progress of Superfund remediation, where the retum on restoration might be quickest, where there are active watershed committees and identified projects, where projects can best be tied together, or other criteria.

\section{The Advisory Council}

The plan should make recommendations on how to refine the Advisory Council. We suggest:

- Each committee member should have technical or policy background on the types of resources that need restoration. For example, biology, hydrology, soil science, public health, etc.

- There should be no elected officials on the committee. However, local government could be represented by local health officials.

- Agencies that might be eligible for funding should not have regular, voting members on the committee. Instead, they should have ex officio members.

- The committee should have at least one member who has a demonstrated familiarity with the claim, settlement language, and the DOI rules and regulations.

The purpose of these recommendations are to ensure that projects are screened objectively and that the review process is kept somewhat insulated from political, pork-barrel and bureaucratic agendas. The committee should have bylaws that include a strong conflict of interest policy, especially in regards to committee members who are consultants. Committee members should be paid for travel, phone and meals.

\section{Annual Restoration Planning}

The proposed Annual Restoration Planning Cycle is simply too lengthy and unwieldy. We don't see why it's necessary to continue the Trustee Restoration Council. The trustee (the governor) can always choose to establish his or her own intemal review group to serve as a screen for annual work plans. The NRD program doesn't need to institutionalize who advises the governor. We recommend a simpler review process:

- Applicants submit proposals to the NRD program, which screens the applications for minimal qualifications AND whether they are appropriate for meeting goals and objectives for basin wide restoration of identified injured resources. 
- The Advisory Council, Tribes and DOI review the applications if they wish.

- After receiving comments from the Advisory Council, Tribes and DOI, the NRD

program prepares an draft annual work plan, which then goes out for public comment.

- After public comment, the NRD program amends the plan if necessary and then submits a final plan for approval and/or modification to the Advisory Council.

- The Advisory Council then sends its recommended plan to the governor (who is free to consult with anyone he or she wishes).

- The governor approves the plan.

This process could occur in much less time than the process described in the draft plan. It also might be possible to craft two funding cycles per year.

\section{Location of Restoration Projects.}

The fear that the settlement could be spent out-of-basin on unrelated projects has merit. But this could be avoided by establishing some basic criteria. First, projects inside the hydrological bounds of the upper Clark Fork basin (above Missoula) should get priority. Projects that are outside the so-called "damage corridor" but inside the upper basin should also be eligible if they directly benefit or replace resources inside the damage corridor (ie., a project on a tributary that produces clean water or fish recruitment to the Clark Fork). Other projects outside the corridor but in the upper basin should also be eligible if there is a clear demonstration that they are necessary and appropriate replacement for injured resources that cannot be restored. The connection should be fairly direct. Projects below Miltown Dam should be considered if they benefit resources upstream. For example, a fishery habitat enhancement project might be eligible if it produces fish for the Clark Fork that could migrate upstream (and passage at Milltown was resolved). Projects outside the hydrological bounds of the upper basin should be ineligible unless it can be conclusively demonstrated they benefit resources inside the Clark Fork drainage. For example, a wildlife habitat project that straddles the Continental Divide could benefit species that use the Clark Fork basin. But these instances will be rare Some have suggested this approach would then justify upgrading Butte's Big Hole water system. We disagree. Upgrading the Big Hole system, which has long been a component of the municipal water supply of Butte, should be considered a normal service of local government. On the other hand, there may be water sources within the Clark Fork basin that could be tapped using NRD funds if the project proponent demonstrates that the venture will replace groundwater identified in the claim as damaged and which cannot be restored.

\section{Funding Research}

The NRD program should establish strict criteria for screening requests to fund research. We recommend that there be a clear showing that proposals target research areas that fill existing data gaps, and that the information gained will benefit restoration activities. We're concerned that without strict criteria requiring research to be tied to actual restoration, that this funding will be viewed as a big pot to fund nominally related research conducted by academic institutions as well as consulting and research firms. 


\section{Funding Existing Programs and Obligations}

The plan needs specific criteria clarifying that NRD funding will not be used to fund normal and existing obligations of government. For example, it should not be used to fund existing or new staff positions unless they are directly tied to Clark Fork restoration. Nor should NRD funds be used for infrastructure that is a normal obligation of local govemment and taxpayers. For example, NRD funds should not be used to upgrade municipal wastewater treatment systems if the work is necessitated by permit compliance or other obligations, such as volumtary nutrient recuction programs that result from TMDL allocations. On the other hand, if professional review by NRD program scientists or others indicates that upgrades of treatment systems beyond compliance levels are needed to advance restoration of injured resources, requests for NRD funding could be considered.

We look forward to our comments being addressed in the final restoration plan.

Sincerely,

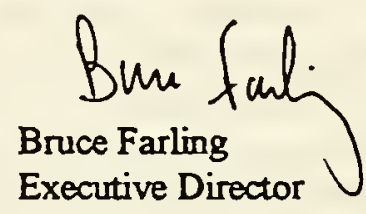

cc. Clifford, Luebeck, Workman, Callahan, Kuipers 
October 15, 1999

Robert Collins

Department of Justice

Natural Resource Damage Litigation Program

P.O. Box 201425

Helena, MT 59620-1425

Dear Mr. Collins:

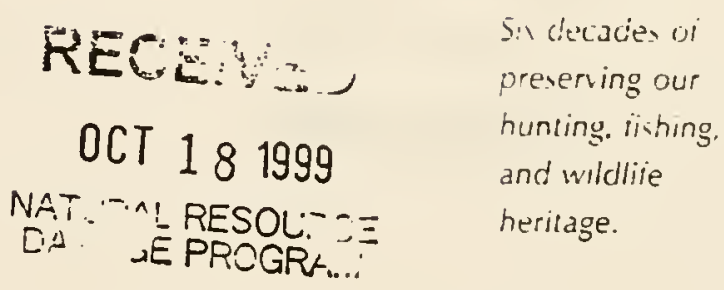

The Montana Wildlife Federation (MWF) is Montana's largest and oldest statewide sporting and conservation organization. Together with ou 23 affiliate clubs, MWF works to conserve wildlife and wildlife habitat, promote responsible government decisions regarding our natural resources, and preserve our hunting and fishing heritage. The Clark Fork is the state's largest river west of the continental divide. Although it is not currently in the best condition, the Clark Fork could foreseeably be returned to a hotbed of fishing and hunting if the restoration plan is implemented discerningly. For this reason, MWF is pleased to be able to comment on the Draft Upper Clark Fork River Basin Restoration Plan Procedures and Criteria.

Overall, MWF feels the document takes a sensible approach. However, we have a number of concerns and suggestions.

1) The procedures and criteria are missing an overall vision or set of goals which will guide project selection and restoration work in the basin. It lays out policies, procedures, and project criteria but no goals. For example, a goal might want to be established for fish populations, i.e. 500 trout per mile of the main stem of the Clark Fork by the year $2010 ; 1000$ trout per mile by 2020; etc. MWF believes that the creation of such goals is a critical step in any planning process. We highly encourage you to include a set of goals in the plan's procedures and criteria document.

2) MWF believes that public access needs to be given a higher priority in the criteria for project selection. It will not help the citizens of Montana to spend $\$ 120$ million dollars of public funds to repair a damaged river corridor only to find that the public is excluded from using these improved resources. What good is it to restore an entire ecosystem if the public is not going to be guaranteed access to mitigate their losses? MWF believes that some form of public access should be a threshold requirement of all types of projects, not just land acquisitions.

3) MWF is concerned with the stipulation that project funding will not be provided until work is completed. Some potential applicants, especially nonprofit organizations will not have access to funds to pay for all project costs up front. Most federal and state agencies have mechanisms to provide startup and staged funding and MWF recommends that similar mechanisms be provided in this program.

4) MWF is concerned with the amount of emphasis placed on monitoring and research. There already has been millions of dollars spent on monitoring and research within this basin. MWF believes that funds acquired through the lawsuit should be used to restore and/or replace the damaged natural resources. Funding research should not be allowed. Funds for monitoring should only be allowed to assure the completion of a project.

5) MWF is concerned with the bureaucratic nature of the project selection process. We feel that the process is too focused on state agency involvement at the expense of meaningful public involvement. In particular, MWF feels that the Irustee Council should be eliminated or combined with the Advisory Council. Being part of the Governor's cabinet, agency directors already have ready access to the Governor if they have concerns. In addition, most of the agency directors sit on the Advisory Council as well. In short, the Trustee Council provides only an unnecessary redundancy. On the other side of this coin, MWF would like to see the Advisory Council's role streamlined. Instead of providing advice to the NRD staff, we believe that they should be providing advise directly to the Governor. It would streamline the process and give the public a greater role in decision-making.

Thank you for the opportunity to comment.

Sincerely,

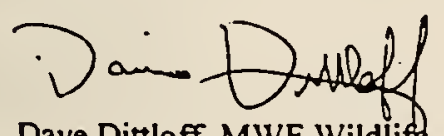

Dave Dittloff, MWF Wildlife Activist Coordinator Letter\#8- 

Mr. Rob Collins

Montana NRD Litigation Program

Old livestock Building

1310 E. Lockey Ávẹnue

Helena, MT 59620-1425
WHYפOYd $\exists$ JWWHO

$\exists$ JUกก

$666 ! 8$ I 190

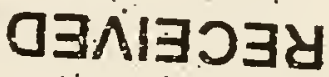

\section{Dear Rob:}

Please consider the Clark Fork-Pend Oreille Coalition's comments on the Upper Clark Fork River Basin Restoration Plan Procedures and Criteria (the Plan). The Coalition has been actively involved in the State's efforts to remediate and restore injured natural resources in the upper Clark Fork basin for over a decade now; and we appreciate the opportunity to comment on this important planning document.

Let me begin by expressing the Coalition's appreciation for the
good work you and your staff have put into this document. The

A) Plan provides an excellent overview of: 1) the injured natural. resources in the basin; 2) the state's lawsuit against ARCO to recover damages for those injured resources; and 3) the criteria that will be used to determine what types of restoration projects will be eligible for funding with the settlement money.

Moreover, the Plan includes a specific requirement that the - settlement money be spent restoring, replacing, or acquiring the equivalent of the injured natural resources in the basin. We support this requirement.

That said, there are a few shortcomings in the Plan that need to be addressed to help assure that injured resources in the basin are restored, and that the public is afforded an adequate opportunity to participate in the restoration planning process. They are as follows:

\section{Lack of Specific Restoration Goals}

Page 29 of the Plan notes that one of the minimum criteria for proposed projects are that they restore, replace, or acquire the 
equivalent of the injured natural resources. We support that requirement. However, we believe the state needs to develop a set of measurable restoration goals for the upper Clark Fork to further define this general requirement. These.goals can be expressed in specific terms-e.g.; number of trout per mile, acres of riaprian habitat restored, miles of spawning tributaries improved-or in general terms-e.g., improve water quality and streamflow, restore riparian habitat, and improve aquatic habitat and fisheries. Regardless of how these goals are expressed, we believe they must be developed. Here's why:

Page 27 of the Plan says "the state believes the preferable approach is to develop and fund annual restoration work plans based on proposals for projects from a variety of governmental agencies, individuals, and private parties". Under this proposed scenario, project proposals will shape the restoration plan for the year rather than having a set of restoration goals. shape the project proposals: We don't oppose the general approach of developing a restoration plan annually, we just think there needs to be a set of restoration goals that project.applicants are trying to meet through their proposals.

\section{Uncertainties Regarding the Role of the UCFRB Advisory Council}

The Plan contains numerous statements about the UCFRB Advisory Council's "significant role" in the restoration planning process; and its ability to provide advice to the Governor on the annual restoration plan. However, a careful read of the Project Evaluation framework laid out on pages $30-32$ suggests that the advisory council's role in the process is quite limited.

The only specific reference to consultation with the advisory council is found on page $3 \cdot 1$, which states that "the Trustee Restoration Council will consider the Program's recommendations and recommendations of the Advisory Council, Tribes, and DOI in making its preliminary decision on the (pre-draft) work plan." The Plan does not contain specific language that ensures the advisory council will be able to weigh in after the public comment period is closed, or that the advisory council will make formal recommendations to the Trustee Restoration Council and/or the Govemor. Given the fact that the NRD Program considers the advisory council a. 
significant part of the public involvement process, this shortcoming must be addressed.

We believe this issue can be addressed in one of two ways. The first, and most efficient way; would be to combine the UCFRB Advisory Council with the proposed Trustee Restoration Council. The proposed project evaluation framework is confusing and cumbersome because it requires review and comment by the NRD Program, the UCFRB, the Tribes, DOI; and the.

(D) Trustee Restoration Council. Combining Trustee Council and the UCFRB Advisory Council would help streamline the review process, and it would assure that citizens on the advisory council have the opportunity to make formal recommendations to the Governor.

If the state decides to keep the proposed Trustee Restoration Council, the Plan must be changed to clarify exactly when the UCFRB Advisory Council makes formal recommendations, and who they make them to. If this approach is taken, we recommend that an additional bullet be added to page 31 (between bullets 6 and 7) which states that "after the NRD Program. incorporates public comment into the final Restoration Work Plan, the UCFRB Advisory Council shall make formal recommendations on project funding to the Trustee Restoration Council and the Governor."

\section{Project Location Criteria}

Page 38 of the Plan discusses the project location criteria that will be used in evaluation process. We generally support this language because it emphasizes the fact that restoration efforts will be focused in the upper Clark Fork River basin. However, the language does appear to leave the door open for money to be spent outside the basin if it is not logistically or economically practical to restore damaged resources in the basin. We believe this language needs to be strengthened. Specifically, we request language be added to state that " the only exception to this criteria will be that if projects extend outside the hydrologic boundary of the upper Clark: Fork River basin, then they must demonstrate a direct benefit to injured resources and/or lost services in the upper Clark Fork River basin"?

4. Unclear Policy on Projects Proposals in Areas Where NRD Claims Are Pending and/or Superfund Remedies Have Not Been Implemented 
Page 10 of the Plan states that "proposed projects must be designed with an awareness of the current conditions of the resources and services, and the factors causing their impaired conditions, and with an intent to improve upon those conditions."

We support this language in the Plan. However, we encourage the State to begin developing a policy for how they will consider funding request for projects in areas where NRD claims are still pending, or in areas where Superfund remedies have not been implemented-i.e., Anaconda Uplands and the mainstem of the Clark Fork River. We anticipate that the State may. receive several funding requests for projects along Silver.Bow Creek and the Clark fork River before the Superfund remedies are complete. Developing a policy on how those requests will be hardled now will be an important step. in helping the public understand which types of projects will be eligible for funding during the first five to ten years of the restoration planning process.

That concludes our comments on the Plan. Again, we appreciate the NRD Programs efforts on developing this document. Please feel free to contact me directly if you have any questions.

Sincerely,

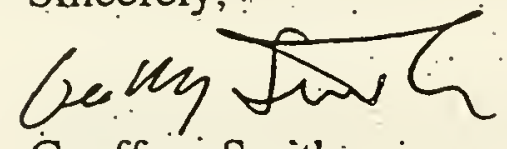

Geoffrey Smith

Technical Director. 


\section{MONTANA ENYIRONMENTAL INFORMATION CENTER}

October 15,1999

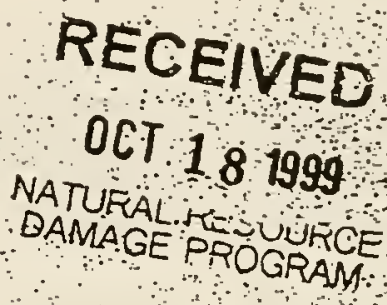

State of Montana

Natural Resource Damage Program

1310 East Lockey, Old Livestock Bldg

FO Bư 20145 Heiena, iNT $59620-1425$

Re: Comments on Draft Upper Clark Fork River Basin Restoration Plan Procedures and Criteria

Thank you for this opportunity to comment on the Draft Upper Clark Fork River Basin Restoration Plan.Procedures and Criteria.

1. Based on the State's natural resource damage assessment, the State's totaf claim in Montana v ARCO was $\$ 764$ million, $\$ 342$ million of which was restoration cost damages. The final settlement has provided the state with $\$ 213$ million. Because the settlement amount is less than that

(A) needed for river restoration, we urge that the full amount be used for restoration projects, rather than economic development.

Highest priority should be given to those projects with the most likely chance of restoring the river's biointegrity - particularly its native fishery.

2. NRDP funds should be confined to activities within the Clark Fork River Basin:

3. The current plan proposes to develop and fund annual restoration work plans based upon nroposals for nrojects from a variety of governmental agencies, individuals. and private entities. While annual work plans are necessary; we urge that they be done in the context of a:

(C) comprehensive plan that prioritizes projects in terms of such considerations as: a) what work is most immediately critical; b) what work will.provide the most "bäng for the buck;". c) what other restoration work is being conducted within the basin (Superfund clean-up; bull trout recovery; Westslope cutthroat recovery, FERC relicensing etc.); d) which sequence of projects is most logical, etc.

4. The amount recovered by the State is insufficient to restore the Clark Fork River to its premining condition and to compensate the public for economic harm. With that in mind, one of the options available to the committee is to recommend that the NRDP funds be placed in a trust in which the principle remains inviolate and only the interest is spent. This will provide a constant source of money that can be used to fund restoration projects along the Clark Fork over the long term. Thus, maximizing the amount of restoration that can be completed on the river. 


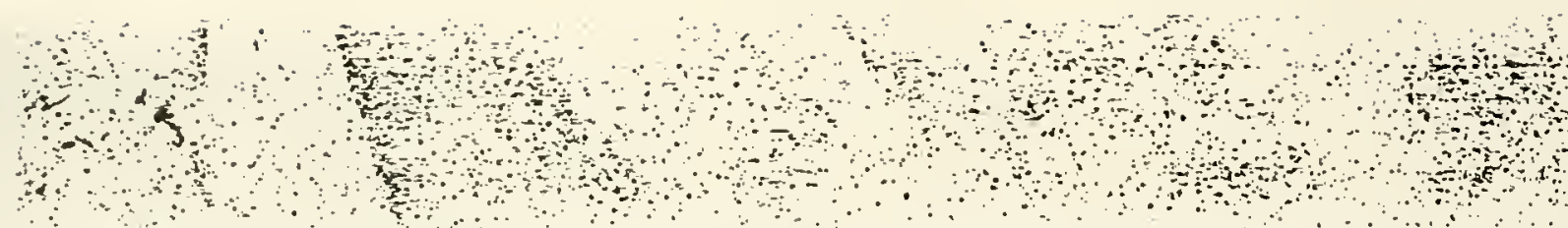

5. It's critical that the management plan have very specific, measurable goals for the settlement

(E) money: This should include such things as: acres of restored riparian habitat, number of trout per mile, volume of surface and groundwater restored, etc.

6. Monitoring is an essential part of any resource recovery plan. We strongly support this element of the plan. We urge that it include a physical, chemical and biological component: The biological (F) : component is perhaps the most important element, demonstrating whether the various restoration abundant wildlife, etc. This portion of the plan is necessary to determine whether reclamation. goals are being achieved.

7. The existing plan states thạt "the State must assess whether a project häs public support." "We urge the Committee to better define this criterion. How will the committee determine whether $\mathrm{a}$

(G) project has public support? What percentage of opposition will trigger a' rejection of a project?

(G) This criterion appears to set the NRDP up as a "popularity contest". in which economic development projects are likely to be more popular than a restoration project which may not provide immediate ecotiomic gains. 'Public participation is an essential part of the process, but should not be the defining factor in whether a project is conducted.

Sincerely,

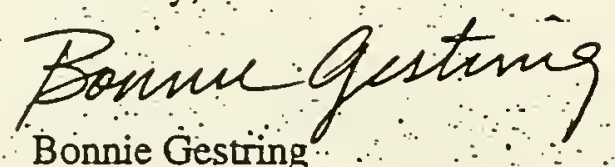

Bonnie Gestring 
October 13, 1999

State of Montana

Natural Resource Damage Program

PO Box 201425

Helena, MT 59620-1425
RECEIVED

\author{
OCT 181999
}

NATURAL RESUURCE DAMAGE PROGRAM

\section{Re: Draft Upper Clark Fork River Basin Restoration Plan Procedures and Criteria}

The Missoula Valley Water Quality Advisory Council has reviewed the Draft Upper Clark Fork River Basin Restoration Plan Procedures and Criteria and would like to provide you with the following comments:

1. We would like to commend you on the criteria you have selected for evaluating and

(A) comparing projects submitted for funding under the restoration program. They are well thought out and appropriate for achieving the best possible restoration of the impacted area.

2. We strongly agree with the philosophy that the actual restoration of injured resources be given funding priority in order to return them to productive use and make them available to future generations of Montanans.

3. We are very pleased to see that the State will consider the extent to which proposed projects are coordinated or integrated with other ongoing or planned actions in the UCFRB and will evaluate projects in the context of the overall ecosystem.

4. We believe this document should include a brief statement of the overall goal of the restoration program and the philosophy that will be used to guide the numerous decisions you will be making as the program proceeds. For example, is your overall goal to restore the areas that are most important to Montanans, based on projects that are submitted, to remediate as many injured resources as possible across the basin, or something else? What philosophy will the NRDP use to identify "gaps" in the work being proposed? Do you have a philosophy on geographical areas that should logically be restored first or for which restoration should be held off, due to either environmental/ecosystem factors or to the status of other ongoing or planned work in the area? What will guide your funding decisions regarding immediate versus future projects and large, localized projects versus smaller, more diverse ones. We feel that the State must develop some sort of overall restoration plan with a goal and guiding philosophy to ensure that the funding is spent appropriately and that the end product - returning injured resources in the UCFRB to productive use - is something that Montanans can be proud of in the end. 
5. We are pleased to see funding available for monitoring the success of individual projects. We would also like to see a plan for tracking the overall success of the program over the years to ensure that the program goals are being met.

6. As we have stated previously, we feel that the report "Restoring the Upper Clark Fork:

Guidelines for Action" by Montana Trout Unlimited, April 1999, is a good general blueprint for restoration of fisheries in the UCFRB.

7. We believe that top priority should be given to projects with the greatest potential to restore

G the river's natural integrity, particularly its native fishery. Of critical importance is the removal or isolation of metals, especially at Milltown Dam, to prevent their further migration downstream.

8. Finally, we hope that the team assembled to review and select restoration projects will include people with appropriate scientific expertise and experience in the UCFRB.

Thank you for the opportunity to comment on the draft document. We appreciate the efforts of everyone involved in this complex and important undertaking.

Sincerely,

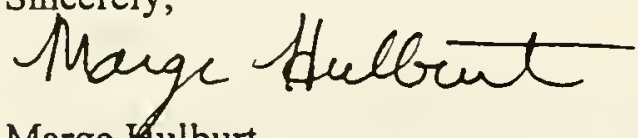

Marge Kulburt

Chair, Missoula Water Quality Advisory Council

cc. Bill Rossbach, Chair, Missoula Water Board 


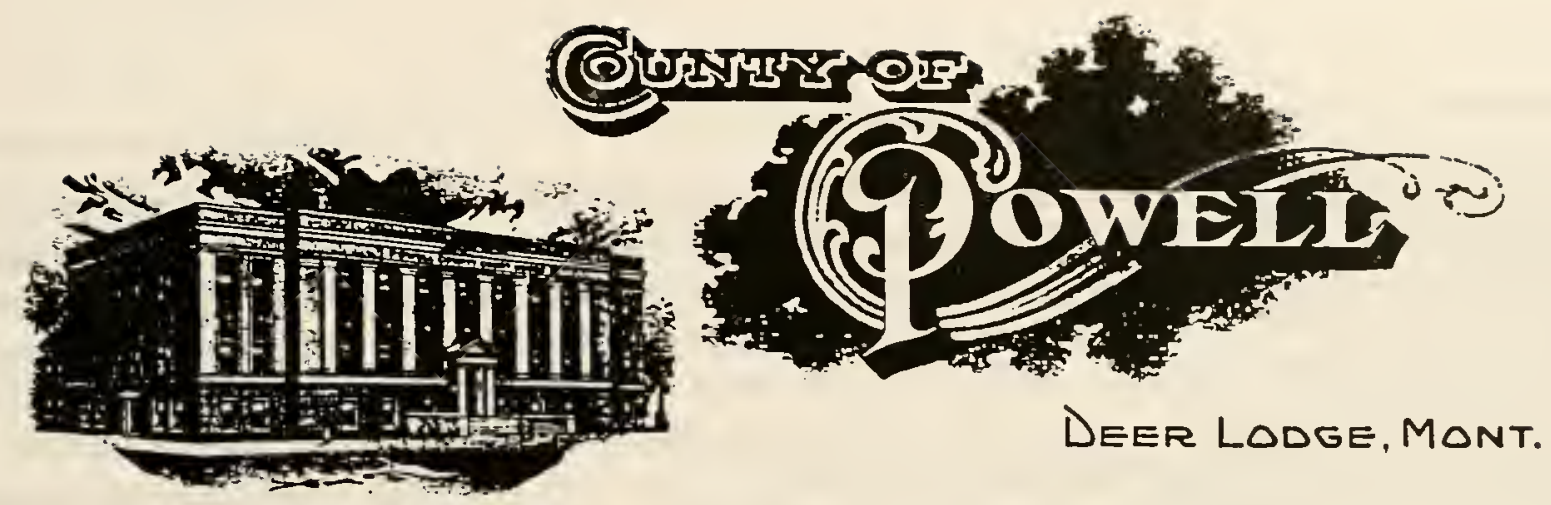

October 15, 1999

Rob Collins

Montana Department of Justice

PO Box 201425

Helena MT 59620-1425

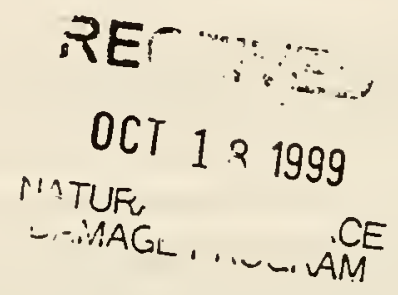

Dear Rob:

Thank you for the opportunity to review the draft of the Clark Fork Basin Restoration Plan Procedures and Criteria. Obviously a great amount of thought and time has gone into the preparation of this document. I hope the following comments might add to its strengths. My comments are keyed to the page numbers and chapters of the document. Some are purely editorial in nature, but in my opinion enhance its usability.

Page 2 - Upper Clark Fork Basin. In the third paragraph you speak to some of the land uses. Quoting from that paragraph, "Recreation - based activities, particularly in the mountains around the City of Anaconda and on various tributaries of the river are important to the area." This comment is accurate, however, it short changes the recreational activities and opportunities that exist

(A) throughout the area, especially those along the river itself. These recreational activities include fishing, water fowl hunting, bird watching, floating, etc. I would suggest adding additional words that more completely describe the recreational activities/opportunities along the river. This background is important in light of the planned Green Way for the upper portion of the river and other potential projects further downstream.

Page 4 - Restoration Cost Damages. Here you talk to both the injured resource and services. I have a feeling that the services for the benefit of people are down played in this Plan. Granted, resources do provide many services and the mere fact that a resource is available has benefit to some people. Regardless, I still feel that injured resources are given undue weight as opposed to services. To support this feeling I reviewed Chapter 2 Injury to Natural Resources and did not find the word "services" in the thirteen page discussion.

Page 26 - Advisory Council. It is difficult for me to understand whether the Advisory Council has any significant role in the entire process. Its charter seems to be to advise the governor and promote understanding of the process. Processes are one thing, projects are something else. To eliminate a local basin wide representation during the project phase seems foolhardy. Some role for the Advisory Council needs to be devised. 
Page 26 - Natural Damage Resource Program. The Natural Damage Resource Program has a very significant role in the project selection. There is no doubt that the Natural Damage Resource Program cannot be done away with while litigation is still a possibility. However, this planning document offers an opportunity for the state to look at who should manage the proposed restoration projects. It may well be that a different entity whose sole purpose and expertise lies in restoration might be a better choice for the future. I submit that the Natural Resource Damage Program may have fulfilled its charter. Rather than looking for opportunities to retain it as an entity, we ought to look to the future and put in place the most appropriate organizational structure.

Much of the remainder of Chapter 3 focuses on activity for the Natural Resource Damage Program. Again, I believe the state needs to look critically at what group should manage the restoration planning process. Whether NRDP is the appropriate group needs serious consideration.

Page 32 - Public Participation. The third paragraph says that the state has attempted to devise procedures that maximize opportunities for the public to express its views. I don't know whether you can, or whether you should, maximize anything in today's environment. Optimize may be a better word choice. I do agree that Internet access is an excellent opportunity for public participation. You need to keep in mind however, that there is a whole group of the public that probably isn't going to have an opportunity to participate through the Internet.

Also under Public Participation you state that the Advisory Council is intended to represent the public and is given a significant role in the funding decisions. On the previous page under Figure 2 it says the advisory council may review applications. If they may review applications, I would question whether they have a significant role in funding decisions.

Also there's a directly affected group of the public that are not mentioned in the document at all. In Powell County those folks are the landowners. To not mention landowners, on whose land restoration projects will undoubtedly occur, is not a smart thing to do.

In Chapter 4 I have a number of thoughts that could make the criteria more understandable and probably more acceptable. My first suggestion is to take the Project Location out of Stage 2 criteria and make it an initial screen with no project being approved outside of the Clark Fork Basin. Your last sentence under Project Location says that you will only consider projects outside the basin which cannot from a practical or economic standpoint be restored. Projects in the basin that are not practical or economical could be put on a list of needs. The intent of those projects which aren't practicable or economical would be valuable things to look at in terms of RFP's.

In my experience the more elements/criteria you have in an analysis process the less useful the results of that analysis are for decision making. Additionally, the people who are affected by the decisions may have a more difficult time understanding the analysis and jump to the conclusion that it is not a fair or scientific process. With that in mind, I would strongly suggest that you rearrange your Stage 1 criteria to provide for a sequential process. The first criteria should be Results of Response Actions. If a response action is going to satisfy the objective of the proposed project the project should be at least delayed. The second criteria should be Technical Feasibility. If it is not technically feasible place its objectives on a needs list. The third criteria should be some merger of 
Relationship of Expected Costs to Expected Benefits, Cost Effectiveness, and Recovery Period and Potential for Natural Recovery. All three of these items represent some form of economic analysis. To attempt to separate these inter-related items out presents a very difficult problem solving approach and provides opportunities to play games on project rating.

Next I would lump Adverse and Environmental Impacts and Human Health and Safety. Under Human Health and Safety you specifically speak to evaluation of the project to have adverse effects on human health and safety. To me this is no different than Adverse and Environmental Effects. Lastly but certainly not least, I think it would be appropriate to merge Federal, State, and Tribal Policies and Laws with Resources of Special Interest to the Tribes and Department of Interior. You're talking about the same thing and to differentiate it again creates unnecessary problems of analysis.

Under General Policy Guides Stage 2 Criteria the Relationship Between Service Lost and Service Restoration could easily be lumped with Project Beneficiaries and Collateral Benefits. Trying to differentiate too many things could make analysis less meaningful. Ecosystem Considerations and Matching Funds should stand alone.

In the area of Public Support I consider it an act of negligence not to specifically identify the landowners as a segment of the public.

Page 39 - Land Acquisition Criteria. Desirability of Public Ownership should be eliminated as a criteria. It is not whether public ownership is desirable but whether habitat protection is achieved. Public ownership is only one way to achieve protection. Also, it needs to be clear that removing additional lands from the tax roles for local government is going to be met with significant resistance. Conversely, the idea of conservation easements may well be beneficial to landowners. Conservation easements or segregation of building development rights could be a positive thing. Finally, I know that Fair Market Value has to be considered. By the same token there are professional appraisers licensed by the state to establish fair market value. To me it is a waist to require the state to conduct its own appraisal.

Under Monitoring and Research Criteria I really don't have many comments. Money spent in these areas ought to benefit the selection and implementation of projects. I especially like the comment that agencies will not be funded for what is prescribed as their normal functions. Obviously most agencies will probably not be able to respond or be willing to respond in their normal area of responsibility without additional funding. That is something that will have to be dealt with.

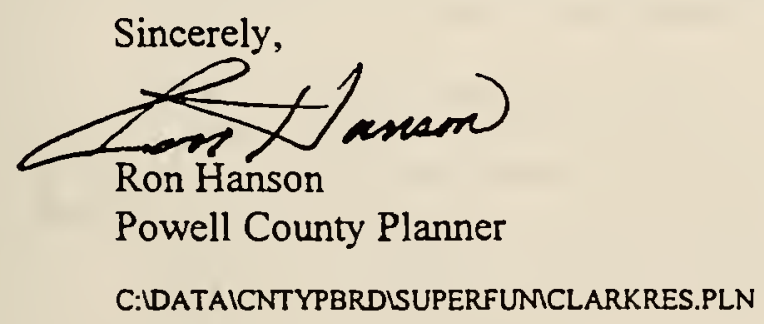



Robert Collins

October 8, 1999

Page Two

members of the Advisory Council that was constructed recently by (C) the Governor, and the Trustee Restoration Council. It appears to committee would be sufficient to adequately assess the needs of those applicants and to make the correct recommendations to the Governor.

On behalf of the citizens of Anaconda-Deer Lodge County, I congratulate you and your staff for the fine work and dedication (D) that has resulted in a document that finally allows the damaged devastation and loss of natural resources. We in Anaconda are in desperate need to replace or acquire the equivalent of the loss of the naturai resource - - water. We hope that through this process we will soon be able to alleviate that concern. I hope my comments are helpful; if you require any further information, please feel free to call on us here at the county.

Sincerely,

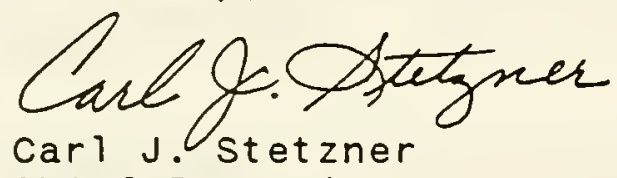

Chief Executive

CJS:mk

File: $\quad$ NRD2.DOC 


\section{ANACONDA-DEER LODGE COUNTY \\ PLANNING DEPARTMENT}

800 South Main

Anaconda, Montana 59711

Phone No. (406) 563-4011

Fax No. (406) 563-4001

\section{RECEIVED}

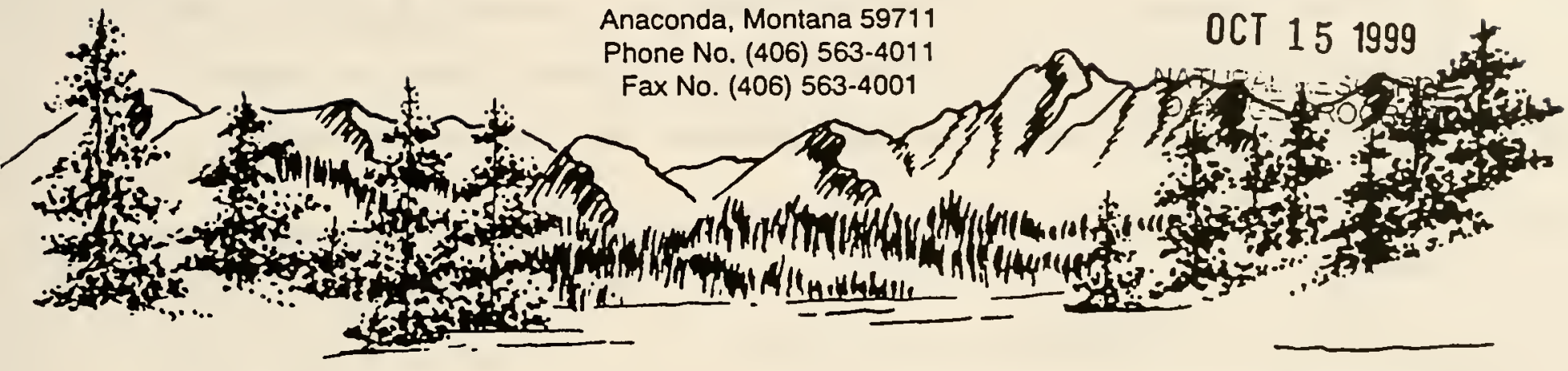

October 14, 1999

Mr. Robert Collins

Natural Resource Damages Program

Old Livestock Building, 1310 E. Lockey Ave.

P.O. Box 201425

Helena, MT 59626-1425

Re: Comments regarding the Draft Upper Clark Fork Basin Restoration Plan Procedures and Criteria.

Dear Mr. Collins,

In response to the proposed Upper Clark Fork Restoration Plan, I offer the following comments.

1. The Advisory Council should have more of a direct role in the review

(A) process, perhaps the Advisory Council and the Trustee Council should be combined for the purpose of review. This would make the process less convoluted.

2. The NRDP staff should not be in a position of both reviewing proposals and requesting RFP's for other projects.

3. Rather than create a new bureaucracy to review proposals, use

(C) existing agencies that have the experience in reviewing and processing grants, such as the Dept. of Commerce CDBDG or TSEP programs. 
4. The projects that fall under monitoring and research should be very carefully scrutinized so that some university professor does not create a

(D) permanent research project to study the river, that has already been

studied to death.

Sincerely,

James M. Manning
Planning Director 


\section{ANACONDA LOCAL DNELOPMEN CORPOARTION}

$10 / 11 / 99$
RECEIVED

OCT 131999

NATURALL $:-O U U R E$ DAMAGE PROGRAM
P.O. BOX 842

118 EAST SEVENTH ST.

ANACONDA

MONTANA 59711

TELEPHONE (406) 563-5538

FAX (406) 563-3275

Mr. Robert Collins, Supervisor

Natural Resource Damage Program

Old Livestock Building

1310 East Lockey Avenue

PO Box 201425

Helena, MT 59620-1425

Re: Upper Clark Fork River Restorative Plan Comments.

Dear Mr. Collins:

Anaconda Local Development Corporation has followed the activities of the Natural Resource Damage action for sometime. The process could have a great positive effect on our community, or it could leave us environmentally lost forever. Our community has been batted around between ARCO, EPA and the State for over eighteen years of Superfund activity. We feel this is the last hope we have to see our community restored to a livable space.

We commend you on the strides you have taken in your second draft of the Restoration Plan. You are moving in the right direction. Respectfully, we submit the following comments on the second draft in hopes of improving on your efforts.

The document must be clear that the settlement funds must be spent on projects that directly benefit the region and its residents. While the entire state benefited from the "gaining" side of mining, it is the local residents that have had to suffer the loss of the aftermath. The dollars must only be spent in the basin.

The restoration plan establishes a decision-making process, which produces conflicts from the beginning. The process is set in a legalistic mode rather that a functional, grant

(C) making mode. The function of litigation should be separate from the project functions. While we recognize ongoing litigation efforts require technical assistance, the two sides should be a separate process with separate entities overseeing the diverse efforts.

The organizational structure of the decision process raises conflict and may place the Governor in a decision-making mode, which is non-productive and potentially divisive causing real gridlock and lost opportunities to restore the region.

We would recommend that the Upper Clark Fork River Basin Remediation and Restoration Education Advisory Council (Advisory Council) and the Upper Clark Fork River Basin Trustee Restoration Council be combined in order to eliminate overlap of 
activity, provide for organized public input (as encouraged by the Montana Constitution), and reduce conflict. The Advisory Council should be expanded to include the Governor's Chief of Staff and the Director of DNRC. The Attomey General should remain in an advisory capacity. The group should also be granted additional responsibilities and authority to move the process along. This is clearly the Governors prerogative to as the Trustee to establish the best advisory group possible.

The newly reformed council will offer the institutional support of staff, citizen's input, and offer institutional memory as the Gubernatorial Chair changes.

We appreciate the flexibility suggested in reviewing projects. The review states requirements may require additional guidelines as the process evolves.

We have a concern that excessive amounts of funds could be spent on research and monitoring activities and not on actual restoration work. Successes can be duplicated from one area to another and numerous new "test pilots", sample data and experiment methods may detract from the real effort. Funds should be limited for R\&D, monitoring while helpful should not be the end goal. Successful efforts can be duplicated and less successful ones not repeated.

We would urge that our recommendations be adopted. We wish you success and are available to expand on our remarks.

Respectfully,

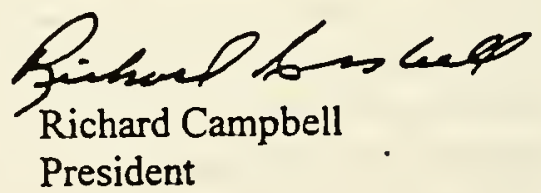




\section{ANACONDA} LOCAL DEVELOPMENT CORPORATION

$10 / 11 / 99$

Mr. Robert Collins, Supervisor

Natural Resource Damage Program

Old Livestock Building

1310 East Lockey Avenue

PO Box 201425

Helena, MT 59620-1425

\section{RECEIVED}

\section{OCT 131999}

NATUFiRL TESUURCE DAMAGE PROGRAM
P.O. BOX 842

118 EAST SEVENTH ST.

ANACONDA

MONTANA 59711

TELEPHONE (406) 563-5538

FAX (406) 563-3275

Dear Mr. Collins:

Thank you for the opportunity to comment on the Upper Clark Fork River Basin Restoration Plan Procedures and Criteria. It is evident that thought has gone into the document. I appreciate the opportunity to make comment to the plan and would ask you to seriously consider both the philosophy of my comments, as well as the specific ideas.

As a preface, having worked in a field for over eighteen years that requires applying for, reviewing, implementing, and reporting on projects funded by grants, there are myriads of grant processes that work well, as well as some that do not. I think you have made a sincere effort of developing a process that includes review, reporting and fairness and encourage openness to many project options. I do foresee inherent conflict arising in the outlined process. I suggest that you streamline the process and lessen frustration and work load for the staff, public, and the decision-makers.

Grant writing can be time consuming, expensive, potentially political, and frustrating. Review, award and administration can be convoluted and take up huge amounts of staff time. I have participated in grant requests that have cost tens of thousands of dollars to prepare, taken years to process and the opportunity to actually carry out the project is lost because the system has taken too much time or is too complex. I see these problems in the proposed process.

Timing of the process is also important. Particularly to coincide with obtaining matching funds, (the cycle could miss out on or attract other funds) construction seasons or personal agendas or needs of private individuals involved in public process.

I would like to suggest several changes to your process;

1) Unite the Upper Clark Fork Advisory/Education Council with the Trustee Restoration Council.

This combines the appointed advisory groups and stakeholders. The Attorney General should remain an advisor. The staff should be interactive with all of these stakeholders. One group makes the process more efficient. This would reduce conflict, cross-purposes and messages, allow input by these directly effected with those working with the problems on a day to day basis. The combination of the council will reduce staff and procedure time and duplication. It will eliminate conflicting advice and make the process "public friendly".

2) Organize the process with long term efrect in mind. Those both applying and reviewing should understand the final goal 20-40 years down the road. Hence the projects should be orderly. In order to assist the public and Trustee Board, it may be helpful to develop a 5-10 year vision as a guide to desired outcomes. Chapter five in the current proposed restoration plan starts this process but a tighter definition established by 
the Council may help the overall effort. Leeway should be made for time-sensitive issues to take opportunity that might be otherwise lost.

3) Have an open time for accepting "white papers" describing potential projects. Some projects might be very worthy but because of timing may not fit in with the overall restoration time frame (i.e. restoring the river below the Silver Bow Creek before Silver Bow Creek is remediated). A proposal may simply not be appropriate or allowable (building an elevator to the top of the Stack in Anaconda). An open white paper process will bring to the attention of the Council an opportunity that may have to bypass the regular procedure (a certain fishing access or easement is available, but may not be if the 18-24 month regular grant cycle). Plans not addressed in the ten-year vision guide could be requested from the public.

4) Staff would review all white papers, make appropriate comments and forward these to the Advisory Council for review.

6) Policy council develops framework of projects, invites pre-applications, and directs staff to develop a pre-draft restoration plan based on framework and the pre-application submitted.

Projects that mẽrit and fit into the restoration framework would be asked to submit a preapplication which details the project more extensively and outlines the desired outcomes, costs, design, restoration area effected, benefits, matching funds, etc. The amount of information required would be in direct relationship to the complexity of the proposal.

7) Council would evaluate the pre-draft restoration and submit to the pubic for comments.

8) Based on comments from the public, and under the direction of the Council, the staff revises the work plan and submits it to the Trustee Council for their recommendation.

9) Policy Council submits recommendation to the Governor.

This process could occur in a quarterly, semi-annual or annual basis, depending on the strength of the vision and framework adopted by the Council.

On another note, all of the funds should be directly spent in the basin. This is where the damage occurred. There is merit in placing the restoration in the contour of the basin to encourage connectiveness to the problems and opportunities.

I ask that you take these comments and suggestions in the spirit they are offered and that the plan be altered. I would be happy to meet with you to expand my comments.

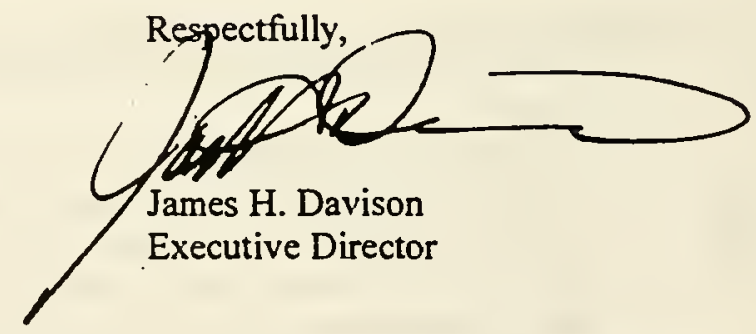


Mr. Robert Collins

September 27, 1999

Page 2

Advisory Council include ten citizens of diversified backgrounds residing in the basin, and the Directors of Fish, Wildlife and Parks, the Department of Environmental Quality and representatives of the Department of the Interior and the Confederated Salish and Kootenai Tribes. Members of this Advisory Council have spent a great deal of time educating themselves regarding the Natural Resource Damage Lawsuit, settlement and damages.

Under this proposal, the Upper Clark Fork River Basin Trustee Restoration Council will also be responsible for recommending restoration work plans to the Governor. The Chairman of the Advisory Council will represent the council as an ex-officio, nonvoting member. It should be noted that the members of this council are virtually the same as the Advisory Council with the exception of the Governor's Chief of Staff and the Director of the Department of Natural Resources and Conservation, resulting in a duplication of effort.

Per the proposed structure, the Tribes and the Department of the Interior will be allowed to (separate from the Advisory Council and the Trustee Restoration Council) consult and comment on the annual restoration plan. It should be noted that the Tribes and DOI are also members of the Advisory Council - another duplication of effort.

We suggest that all input come from one body. We recommend the Trustee Restoration Council, and the Advisory Council be combined into one Upper Clark Fork River Basin Remediation and Restoration Education Advisory Council (already in existence). Since the Tribes, DOI and the Directors of the Departments of Environmental Quality and Fish, Wildlife and Parks all sit on the Advisory Council, we recommend adding the Governor's Chief of Staff and the Director of the Department of Natural Resources and Conservation. The Attorney General may advise the council as outlined in the draft. This council will then review all proposals and make one unified recommendation to the Governor. This structure would eliminate the risk of conflicting recommendations and will preserve the input of all interested and informed parties, including the public.

In closing, we hope you give our comments and recommendations serious consideration. Please advise if we can provide any additional information.

Sincerely,

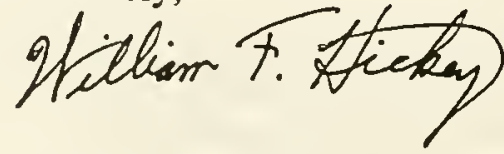

William F. Hickey

President 
Mr. Robert Collins, Supervisor

Natural Resource Damage Program

P.O. Box 201425

Helena, MT 59620-1425
RECEIVED

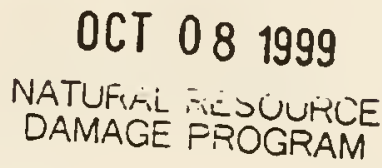

Dear Mr. Collins:

Re: Draft Upper Clark Fork River Restoration Plan

I am pleased to see that much consideration was given to comments received from the Upper Clark Fork River Basin Remediation and Restoration Education Advisory Council in the current plan proposed for dealing with this very important program. Your willingness to listen to the views of interested persons and groups certainly gives the general public confidence that their opinions are valued.

I have been involved with the cleanup of the Anaconda-Deer Lodge County area since almost the beginning. There are still some areas of concern to me. It is my firm belief that the moneys received from the lawsuit must be spent in the Upper Clark Fork River Basin only. Certainly this was the area which was damaged through the years, and it is here that our resources must be protected, restored, and replaced. Other areas of our state received the benefits of revenues generated by taxation of the mining industry here, but it was our area alone that bore the destruction which produced those state revenues. It is this damaged area that generated the moneys from this lawsuit, and that is where the moneys should be spent.

$<$

I believe, too, that there are two separate functions within this program,

C) restoration planning and litigation. Each should be separate and distinct. I feel that the comingling of policies and procedures will reduce the efficiency of each and cloud the main mission of the program.

I have this same concern when I try to understand the roles of separate and distinct councils and stand-alone entities which, the draft indicates, will consider the issues and make recommendations to the Governor. Many of the same people are represented on both the Advisory Council and the Restoration Council, so that certainly

D appears to be redundant. One council which includes both the Restoration and Advisory Council members as well as the Governor's Chief of Staff and the Director of the Department of Natural Resources and Conservation should certainly be able to study all the issues and make the recommendations to the Governor. The Attomey-General should, of course, serve in an advisory capacity.

I appreciate your giving the public time to comment on this current draft proposal, and hope my comments may prove helpful.

Sincerely yours,

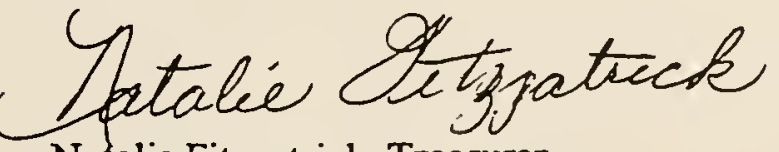

Natalie Fitzpatrick, Treasurer

Arrowhead Foundation 



\section{BUTTE-SILVER BOW \\ Office of Council of Commissioners \\ Courthouse \\ Butte, Montana 59701}

RECEIVED

OCT 151999

NATURAL R.¿JUURCE DAMAGE PROGRAM

\section{Memo}

Date: $\quad$ October 14, 1999

To: $\quad$ Robert Collins, Supervisor

Natural Resource Damage Program

From: Butte-Silver Bow Council of Commissioners

Ed Heard, Chairman \&H.

CC: $\quad$ Marc Racicot, Governor

Judy Martz, Lieutenant Governor

Joseph Mazurek, Attorney General

Jack Lynch, Butte-Silver Bow Chief Executive

Robert M. McCarthy, Butte-Silver Bow County Attomey

Members, Butte-Silver Bow Council of Commissioners

Butte-Silver Bow Technical Review Committee/Environmental

Butte-Anaconda Members, Montana Legislative Delegation

Members, Greenway Authority Board

Rick Giffith, President, Project Green

Re: $\quad$ Butte-Silver Bow's Comments on the

Draft Upper Clark Fork River Basin Restoration Plan Procedures and Criteria

On Wednesday, October 13,1999, the Butte-Silver Bow Council of Commissioners took formal action to approve the submission of the attached comments regarding the Draft Upper Clark Fork River Basin Restoration Plan Procedures and Criteria. We hope you find the comments useful in producing the final draft.

Butte-Silver Bow would also like to express our thanks for the efforts of you and your staff to improve this document (from the first release last June). We appreciate your willingness to respond to the input received from local residents. We hope you will extend those efforts in response to these comments we submit today.

Thank you for the opportunity to submit these comments on behalf our community. 


\section{Final Comments (October 14, 1999) \\ from Butte-Silver Bow on the \\ Draft Upper Clark Fork River Basin Restoration Plan Procedures and Criteria}

Butte-Silver Bow has prepared the following comments in response to the request from the State of Montana. The comments were unanimously approved for submission by formal action of the Butte-Silver Bow Council of Commissioners at a special meeting on October 13, 1999. First, we present general comments applicable to the entire Draft Plan, and then more specific comments in chronological order according to the chapters of the Draft Plan.

\section{General Comments}

- Without exception, the procedures must provide assurance that all projects funded by proceeds from the settlement are located within the Upper Clark Fork River Basin (Basin) where the damages occurred and the benefits of all projects directly accrue to the resources and communities in the Basin. There is substantial work to be done within the Basin and there is simply no need to pursue projects outside the Basin.

- The local communities in the Basin must have a primary role in decisions regarding how proceeds are used; more precisely, the Governor's Advisory Council should be combined with

(C) the Trustee Council to form one advisory body and a direct role in the decision-making process.

- The "litigation arm" of NRD staff should be separated from the so-called restoration

(1) arm" of this same staff. Further, the administration and management (i.e. local office) of the restoration work should be located in the Basin where the projects will be executed.

- There needs to be strict accountability for funds set-aside for the Streamside Tailings cleanup,

(E) particulariy for engineering/administrative/contingency costs; also, that the project should address both remediation and restoration to the maximum extent possible, including the construction of a greenway as the final land use. We believe strongly that there are sufficient funds to achieve both objectives.

- There must be greater emphasis on a comprehensive plan for the entre Bastin, Hot sinply

F) procedures and criteria about how individual projects will be selected and funded. We believe strongly that remediation and restoration projects must be accomplished at the same time, and a blueprint for action should be developed to ensure that occurs.

\section{Chapter 1: Introduction and Background}

Page 4: Note the important reference about using the terms "restore" or "restoration" in the document generally refers to all four types of actions to be authorized - restoration, rehabilitation, replacement, and acquisition of equivalent resources. Later in Chapter 4, using the one word to represent all four actions can be misleading. 
Page 8: Constraints imposed by settlement on restoration funding, second bullet: The State must spend at least $\$ 500,000$ on bull trout restoration. Granted, this work was imposed via the consent decree, but if restoration of native species is a priority, we should also focus our efforts on the Westslope cutthroat trout. Further, it should be a prerequisite that all fish restoration projects, including those for bull trout, must be conducted in the Basin.

\section{Chapter 2: Injury to Natural Resources}

In general, this Chapter explains the remediation work in the Basin that has occurred to date. We would suggest more graphics, pictures, and descriptions of the completed and ongoing remediation projects to provide an increased understanding of this work, especially in the context of restoration projects that will be proposed in the same areas.

Page 12: Regarding the Berkeley Pit: Use the word "approaches" instead of "reaches" the CWL of 5,410 to better reflect the remedial action specified under the Record of Decision; also, based on current data, the estimated year the CWL will approach the CWL is 2021, not 2025 .

Page 12: Regarding Butte Area One: The description perpetuates the false characterization of the historic Silver Bow Creek channel as the present day Metro Storm Drain. The drainage should be described accurately, particularly in regard to the damage/injury to the natural resource. Also, the Parrott Tailings lie along and "northeast" of the historic Silver Bow Creek . channel above Harrison Avenue, not "northwest."

Page 14: Regarding the Silver Bow Creek Aquatic and Riparian Resources: The four sections do not add up to 26 miles?

\section{Chapter 3: Restoration Planning Process and Implementation}

It is disturbing that the role of the Advisory Committee is diminished in favor of the Trustee Council. As an alternative, the Trustee Council should be combined with the Advisory

(M) Council to form one collective decision-making body. The expanded, citizen-based Advisory Council would be less vulnerable to political and administration changes, and its role would be elevated and more directly linked to the Governor, as trustee. Further, the decision-making process described in this chapter (and depicted on Figure 2) is unnecessarily complicated and should be simplified to reflect the direct role of the expanded Advisory Council to represent the citizens in the Basin.

Page 26: NRD Program: The "litigation arm" NRD staff (working on the three remaining restoration claims in the lawsuit with ARCO) should be separated from the so-called "restoration arm" of this same staff. The process, planning and general activities of restoration is and should be distinct from the litigation. Also, the administration and management of the restoration work should be located in the Basin where the projects will be executed. 
Page 28, B. Project Applications and Minimum Qualifications last paragraph on the page: applications for projects costing $\$ 5,000$ or more will call for a fairly high level of detail. The arbitrary funding level would appear to be rather inconsequential in the big picture, i.e., how many worthwhile restoration projects would cost less than $\$ 5,000$. We believe every project should follow the same application procedures. As for small projects (e.g., non-profit organization sponsoring a clean-up project), the procedures should be set up to allow some flexibility that would not require a full-blown proposal; for example, projects less than $\$ 5,000$ could request funds through a short form.

Page 29: "initial application screening": Since there is no detail yet about the submittal requirements of a full proposal, it may be premature to judge this "initial application screening" step. However, the screening appears to be rather substantial. It may be better to establish some sort of formal "Pre-Application" step, whereby prospective applicants could get a more formal "heads=up" from the State on the viability of a project before going through the more difficult process (and substantial work) of preparing a comprehensive proposal. In addition, as part of a screening process, there should be consultation with the governing body in the area where a project is proposed to avoid conflict with local work that may be planned or underway independent of projects funded through the NRD program.

Page 29: Regarding project development funding: This idea is not in the best interest of ensuring restoration dollars are spent on restoration. One major tenet of the program has been explicit - that restoration money must be spent on projects tangibly benefiting the basin on the ground, not in the development stages or collecting further data. Requiring the applying entity to do these tasks in house before any money is awarded will result in better planned projects and in effect, bolster the entire encouragement of cost efficiencies referred to in the fourth bullet of Chapter 3, A. The Annual Cycle and Eligibility to Submit Project Proposals, p. 28. Also, making subjective decisions on which groups to grant "development funding" places unnecessary pressure on the decision-makers.

Page 30: NRD staff consultation: Why will it be mandatory to consult with FWP on proposed fish projects and elective to consult with others on non-fish projects? Also, how will consultation be handled on projects that are proposed by State agencies? There appears to be a strong potential for a conflict of interest on projects proposed by state agencies. For example, will one arm of FWP be asked to consult on a fish project proposed by another arm of FWP? Likewise, how will public comment extend to the proposed projects - can the public "secondguess" the evaluation process late in the game and kill a project after it has been reviewed under the criteria and recommended for funding?

Also, regarding the process, it is not entirely clear how the Restoration Plan itself, and the list of projects to be recommended for funding will interrelate. For example, if more than one project is proposed to address the same resource in the same area, how will it be determined which project (or both) will be recommended for funding? What about a project that meets all the criteria but is out of sequence - e.g., a downstream project that may be compromised by 
work still not done upstream? A missing component to the chapter is an overall plan that puts everything in perspective and begins to outline priorities/projects in the restoration process.

Page 31-32, Figure 2, Annual Restoration Planning Cycle: As stated, the role of the Advisory Committee appears to be secondary, not significant, in the process outlined in Figure 2. It appears as though the Advisory Committee will advise the NRD staff, or at best the Trustee Council, rather than provide direct input to the sole trustee, the Governor. The Figure should be simplified and Butte-Silver Bow would support the alternative process advocated by the Advisory Council.

(4) Page 33: Project Implementation, Follow-up, and Monitoring: First, the threat of termination (in this document) is unnecessary and overstated. There is standard contract language to deal with implementation failures. Second, there appears to be an inherent conflict for the State to reserve the authority to approve all designs and then claim indemnity from any liability for projects that don't work. We would suggest that the NRD staff role, beyond their participation in the project selection process, be limited. The burdens of project design, construction, oversight, and overall implementation should be placed on the applicant. We need to avoid creating a perpetual money machine for consultants. Third, we would also suggest the State consider some type of advance payments to grantees who may not be able to afford fronting the costs of their project.

\section{Chapter 4: Criteria of Decision Making}

In applying the criteria, the proposed process is to NOT rate and assign values, nor grade projects numerically. Although this proposed approach does have its merits, it portends to be rather subjective, and has the effect of concentrating the decision-making authority with the NRD staff. If the State prefers this non-quantitative approach to evaluating projects, then it is imperative that the role of the Advisory Council be elevated to ensure meaningful involvement in the project evaluation process.

(2) Page 35: Technical Feasibility: "technologically infeasible impossible" appears to have an extra word?

Page 36: Results of Response Actions: This criterion appears to be mischaracterized. More accurately, shouldn't it be "Consistency with Response Actions," as it is described well in the first bullet on page 37. Consistency of a proposed project with what has already been done at the site/resource is the crux of the criterion; the previous paragraphs seem to imply some level of subjective interpretation that would be better left for Stage 2 evaluation.

Page 36: Resources of Special Interest to the Tribes and DOI. We would suggest inserting more explanation as to why this criterion is imposed. Wasn't the federal mandate to address such resources already addressed as part of the separate settlements with the Tribes and DOI? Why is it necessary to grant extra weight in these Stage 1 criteria for all projects? 
Page 38: Stage 2 Criteria, Project Location: This is a key criterion and a chief concern of the people who live in the Basin and have suffered the loss of impacted resources. In essence, it appears the language that describes this criterion, particularly words like "ordinarily" or "most of" and the entire sentence about the "only exception..." opens the door for projects outside the Basin to be funded. The language should be tightened up considerably to ensure all projects are within the Basin and where the damages have occurred. The point has been made many times that there is more work in the Basin than there is money to get it done, thus, it seems rather inconsistent to reserve the authority to spend money on projects outside the Basin.

Page 39: Ecosystem Consideration, Coordination and Integration. Isn't this criterion (DD) already covered under the Stage 1 Criteria? Also, it would appear that the criterion has the potential to create an unnecessary bias toward projects that restore resources vs. replace.

Page 39-40: Land Acquisition Criteria: Having separate criteria of land acquisition projects would appear to imply that the use of the "restore" and "restoration" in the general policy criteria do not apply to acquisition projects. Are these criteria extra, or mutually exclusive from the general policy criteria? In any event, a threshold criterion for any land acquisition projects must be its location within the Basin; no land should be acquired outside the Basin to replace lost resources within the Basin.

Also, regarding the sub-paragraph on Public Access, this should receive greater emphasis to promote public access through land acquisition, and not just for publicly owned lands. What good is it to restore an entire ecosystem if the public (i.e. the citizens impacted the most) is not going to be guaranteed access to mitigate their losses? Public access granted through easements and/or public ownership should be a threshold requirement of any land acquisition project. Further, we would suggest that public access should be part of the criteria for all types of projects, not just land acquisition projects.

Page 40: Monitoring and Research Criteria: Again, are these extra criteria, or mutually exclusive of the general policy criteria? The separate criteria imply some special significance to such activities. No projects should be funded if the sole deliverables are to learn more about the UCFRB. Monitoring should be allowed only to measure the results or benefits of a proposed projeci - not be a project in and of itself. As for research, no settlement funds should be spent on research projects and sponsors who wish to pursue research in the Basin should seek alternative funding sources.

\section{Chapter 5: Types of Eligible Restoration Actions}

The entire chapter does not appear to add much value to the Plan. First, the discussion appears to endorse monitoring, research, and administration as eligible activities, which consequently diverts funds away from bona fide restoration activities. Second, the discussion places emphasis on research that is unwarranted. Third, text fails to place restrictions on administrative expenses. Fourth, the various examples of projects have the potential to mislead prospective applicants as to the type of projects that will be funded. 
Page 43: Replacement/Acquisition Projects: The entire discussion of replacement and acquisition projects should be prefaced with a clear understanding that such projects must occur WITHIN the basin where the damage occurred.

Page 44: Limitations: The explanation is not clear. What is the message? As written, it appears to be an attempt to justify "off-site" projects. The explanation leaves too much open to speculation about off-site projects replacing resources off-site, and not within the basin.

Page 44-45: Monitoring and Research: There has been enough monitoring and scientific research within the UCFRB to fill the Berkeley Pit with data. Perhaps the missing link is to disseminate all the existing data for the Basin, e.g., as stored in the Upper Clark Fork Data Management System housed at DEQ. We would advocate that no further funds be allocated to any type of research/monitoring oriented type projects unless such projects are directly attributed to monitoring the success or failure of a specific remedial action or restoration project. As for the stated justification of research to guard against misdirected projects, we would state that if any proposed project has the potential to be misdirected, it will likely fail on its merits, based on all the evaluation criteria. There is plenty of work to do in the Basin without having to reach for marginal projects.

Page 45:Administration: There needs to be a limit as to how much money can be spent on administration. For example, if there are people hired within the program as technical specialists, there should not be a substantial need to obtain independent scientific review, overseeing and evaluating monitoring results and any scientific research, and/or reviewing project applications. The last sentence - The State will endeavor to minimize these expenses. - has little credibility unless there is a willingness to impose a cap on such expenses and release detailed expense reports on a regular basis. We must provide the public with assurances about the State's "endeavor."

\section{Closing}

We would be remiss to submit these comments without acknowledging the effort by the NRD staff to improve this Draft Plan (compared to the first draft released in June). Clearly, several comments provided over the past several months by the Advisory Council and others in the Basin have been incorporated into the latest release (dated September 10), and as a result, the Draft Plan is getting better.

Nonetheless, additional revisions are warranted to make the Draft Plan even better. Please accept these comments from Butte-Silver Bow in the spirit of cooperation and as part of our continuing effort to work together with the State and our neighbors to maximize the benefits from restoration activities on behalf of the natural resources and residents of the Upper Clark Fork River Basin. 



\section{is

RECEIVED

$10 / 14 / 99$

Natural Resource Damage Program Public Comments

Natural Resource Damage Program

Department of Justice

Capital Station

Helena, MT 59620
OCT 151999

NATUFIL MEOUURCE

DAMAGE PROGRAM

Re: Public Comment on "Draft Upper Clark Fork River Basin Restoration Plan Procedures and Criteria"

The Butte Local Development Corporation (BLDC) Board of Directors wishes to formally comment on the Natural Resource Damage (NRD) program as proposed in the "Draft Upper Clark Fork River Basin Restoration Plan Procedures and Criteria" dated September 10, 1999.

For the last 30 years, the BLDC has been the lead economic development organization in Butte-Silver Bow and works extensively in economic and community development throughout Southwest Montana, including areas along the Upper Clark Fork River Basin (UCFRB).

The BLDC has a Board of Directors that numbers 15, and these views reflect the collective views of the Board as adopted formally by the Board. Further, the BLDC has approximately 100 members and member businesses.

First, we wish to associate ourselves with the positions taken by the local government of Butte-Silver Bow.

More specifically, we urge changes in the draft to reflect the following:

1. All NRD money must be spent for projects in the Upper Clark Fork River Basin (UCFRB) "damage corridor" -- no exceptions should be made. In fact, the NRD program should not even consider applications for restoration projects outside the damage corridor. (see suggested attached language)

2. The NRD Restoration Office should separated from the litigation function (lawsuits are the specialty of lawyers - cleanup and restoration aren't) and should be located in the UCFRB, close to the restoration and the affected people. (These issues are not referenced at all in the draft document and, thus, should be added.) 
3. Local people from the area should be more empowered in the NRD process -- to the level of decision-making. The UCFRB Advisory Council should be merged with the proposed "Trustee Council", to provide local involvement at the decision-making level. In other words, the current "Advisory Council" should be dissolved and the proposed "Trustee Council" should be expanded to D) include the membership of the "Advisory Council" as appointed by the Governor. As a matter of clarification, the "NRD Policy Committee" that was created to advise the Governor on NRD litigation could continue with that function for future NRD litigation issues, but would not be de facto the "Trustee Council" as proposed. The Trustee Council should be structured, as requested above, to include local representation beyond the token representation recommended in the draft.

Please consider these comm̃ents, and make appropriate changes in the document.

We are available for consultation if it is desired.

On behalf of the BLDC Board of Directors, I am

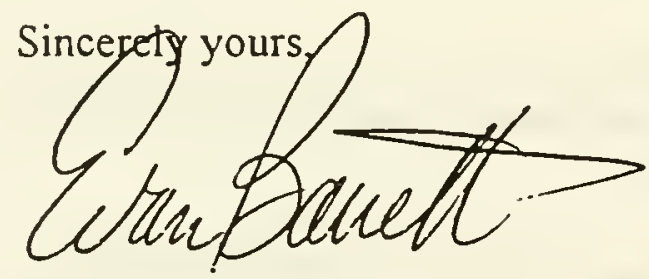

EVAN BARRETT

Executive Director

Cc: BLDC Board of Directors

Project Green of Montana, Inc. Board of Directors

UCFRB Advisory Council Members

Greenway Management Authority Board Members

Butte-Silver Bow Council of Commissioners

Butte-Silver Bow Legislative Delegation

Governor Marc Racicot

Lt. Governor Judy Martz

Attorney General Joe Mazurek

Secretary of State Mike Cooney

State Auditor Mark O'Keefe

Enc: suggested language re: item 1 above 


\section{Specific Language Change Needed in Draft Upper Clark Fork Basin Restoration Plan \\ Procedures and Criteria \\ As Proposed by the \\ Butte Local Development Corporation \\ Regarding Item \#1 on Comment Letter}

On page 38 , under Project Location, language should be changed to read as follows

Edited version

Project Location This criterion focuses on the location of the project-and the project. While the statê recovered natural resource damages on behalf of all of its citizens, restoration efforts are to be focused exclusively on the Upper Clark Fork River Basin. This decision by the trustee in the adoption of this plan follows from the natural resource damage provisions of CERCLA and CECRA. By allowing trustees to recover damages to undertake restoration actions to redress natural resources injuries, the statutes create a direct relationship between those actions and the specific natural resources that have been injured. One of the most important elements of this relationship is geographic, requiring thestoration actions occur at or near the site of the injury. In addition, this is a matter of fundamental fairness. The people of the UCFRB have lost the most as a result of the injuries to natural resources and services. Accordingly, they should receive of the benefits from actions to improve the condition of injured resources and services. Based upon the state's natural resource damage claim before the Federal Court and given the recognized widespread injury to natural resources in the UCFRB. the State of Montana believes that there are more restoration, rehabilitation, replacement and/or acquisition actions required in the UCFRB damage area than could ever be accomplished with the limited monies received in the NRD settlement. Because of that, there is no need to look towards doing any restoration projects outside of the UCFRB itself, and the NRD program will not consider proposals for any such projects. The exception th geographic requirement would apply to projects which restore resources or services which have been injured or impaired in the UCFRB but which cannot, from a practicatoreconomic-standpoint, be restored in the UCFRB.

Clean revised version

Project Location This criterion focuses on the location of the project. While the state recovered natural resource damages on behalf of all of its citizens, restoration efforts are to be focused exclusively on the Upper Clark Fork River Basin. This decision by the trustee in the adoption of this plan follows from the natural resource damage provisions of CERCLA and CECRA. By allowing trustees to recover damages to undertake restoration actions to redress natural resources injuries, the statutes create a direct relationship between those actions and the specific natural resources that have been injured. One of the most important elements of this relationship is geographic, requiring that 
Language Change Needed in Draft Upper Clark Fork Basin Restoration Plan Procedures and Criteria 10-14-99

Page 2 of 2

restoration actions occur at or near the site of the injury. In addition, this is a matter of fundamental fairness. The people of the UCFRB have lost the most as a result of the injuries to natural resources and services. Accordingly, they should receive the benefits from actions to improve the condition of injured resources and services. Based upon the state's natural resource damage claim before the Federal Court and given the recognized widespread injury to natural resources in the UCFRB, the State of Montana believes that there are more restoration, rehabilitation, replacement and/or acquisition actions required in the UCFRB damage area than could ever be accomplished with the limited monies received in the NRD settlement. Because of that, there is no need to look towards doing any restoration projects outside of the UCFRB itself, and the NRD program will not consider proposals for any such projects. 


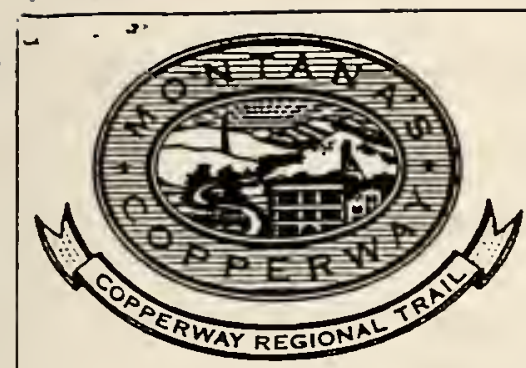

Greenway Service

District

Anaconda-Deer Lodge and Butte-Silver Bow Counties

Management Board

Russ Bilodeau

Larry Curran

Ron Hanson

Meg Hickey

Brian Holland

Milo Manning

Joe Shoemaker

Dori Skrukrud

Lorry Thomas

October 15, 1999

Mr. Robert Collins, Supervisor

Natural Resource Damage Program

Old Livestock Building

1310 East Lockey A venue

P.O. Box 201425

Helena, MT 59620-1425

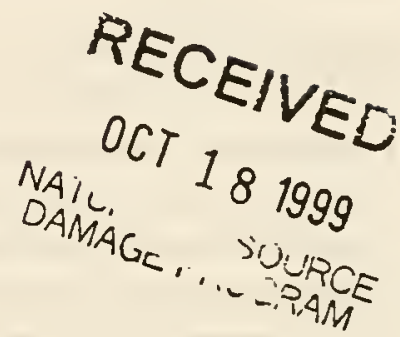

SUBJECT: Comments regarding the Draft Upper Clark Fork River Basin Restoration Plan Procedures and Criteria

Dear Mr. Collins:

- On behalf of the Greenway Management Authority, I respectfully submit the following comments regarding the most current version of the Draft Upper Clark Fork River Basin Restoration Plan Procedures and Criteria (Draft Plan).

The Greenway Management Authority has carefully reviewed this document and appreciates the opportunity to comment on this critical step in the Natural Resource Damage Program (NRDP) process. We would like to commend the NRD staff for their efforts in revising the initial draft of this document; this version of the Draft Plan reflects considerable deliberations regarding the future of the Program. The administration of the settlement proceeds is of the utmost importance to the future of the Upper Clark Fork River Basin and of considerable concern to our organization as we look forward to the future remediation and restoration of the Silver Bow Creek corridor

We believe that all restoration projects funded by the settlement proceeds must be located within the Upper Clark Fork River Basin, where damages occurred. In that regard, we believe one of the criteria missing from the Draft Plan is a section providing that the comprehcrivive plan should bear some relationship to the claims released. Among the six claims for which ARCO received a release of natural resource damage liability, five sites are located above the Warm Springs Ponds. Common sense dictates that since the State received a lump sum payment in exchange for the release of certain specific claims, the restoration plan should factor in which claims were released in determining which restoration projects will be funded.

Anaconda, MT 5971

$406 / 563-4011$

- or -

County Courthouse

$155 \mathrm{~W}$. Granite

Butte, MT 59701

$406 / 497-6253$

The General Policy Criteria of the Draft Plan should explicitly provide that any decisions or work plans developed for projects within the Basin must be consistent with Record of Decision (ROD) relative to a specific site or resource. For example, in the ROD for the Streamside Tailings Operable Unit, page 113 of the ROD states:

"Provided that the final design of the SSTOU remedy can attain the cleanup criteria and performance standards, it should be to the degree Dossible 
incorporate components consistent with the following environmental and community improvement actions in the project area:

- A Silver Bow Creek recreational corridor land use as designated and adopted by the Butte-Silver Bow and Anaconda-Deer Lodge County governments;

- Preservation and enhancement of significant historical and pre-historical resources in accordance with the Regional Historic preservation Plan;

- Coordination with pertinent restoration actions implemented as part of the Upper Clark Fork River Basin natural resource damage restoration claim."

Page 8 of the Draft Plan includes the statement "Remedy implementation along Silver Bow Creek is expected to cost approximately $\$ 80$ million, plus the interest accruing thereon." We request that this sentence be deleted or rephrased. With respect to the cost estimates for the remedial action within the SSTOU, we recognize that there have been cost estimates as high as $\$ 80$ million plus interest for the work. We believe that the final cost of cleanup should be less than this estimate and, further, if remediation and restoration work is coordinated, the State should realize a savings because of the cost-effectiveness of conducting these two actions simultaneously.

We would also contend that the funding for the SSTOU remedial action, the Streamside Tailings Operable Unit Fund (SSTOU Fund) comprised of $\$ 80$ million plus interest, is intended to be spent on this site, as stated in the settlement. If the cost of the response action along Silver Bow Creek is less than $\$ 80$ million plus interest, any excess monies in the SSTOU Fund should be prioritized for natural resource restoration projects within or related to the SSTOU site as opposed to projects within the Basin in general.

We would also urge the strengthening of the body that ultimately makes recommendations to the Governor, as Trustee of the NRDP, regarding worthy restoration projects and the final disposition of funds. We believe that the two councils, the Trustee Restoration Council and the Governor's Advisory Council, should be combined. This consolidation will avoid potential conflicting recommendations to the Governor and continue the exemplary work of the Advisory Council. The Advisory Council's individual members have spent countless hours educating themselves about the NRDP, the damages and loss of natural resources within the Basin and the preferences and opinions of the communities they were appointed to represent. To diminish or jeopardize their role in the decision-making process would fail to appreciate the work that was done on behalf of the State of Montana and the Upper Clark Fork River Basin. Each Advisory Council member, as appointed by the Governor, brings a unique perspective to the debate, with an overriding responsibility of representing the community at-large.

Finally, the litigation and restoration divisions of the NRD program should be operating independently. This will allow the litigation division to focus on the resolution of continuing lawsuits while the restoration division can implement the Restoration Plan.

In closing, we appreciate the work that has been committed to bringing the Draft Plan to this date and request your consideration of these comments. Thank you.

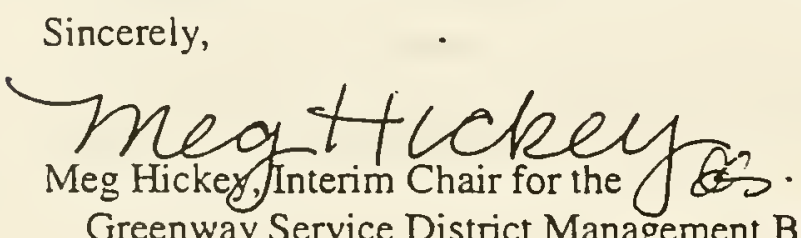

Greenway Service District Management Board 


\section{RECEIVED}

\author{
Project Green Steering Committee \\ 3431 Hannibal \\ Butte, MT 59701 \\ October 12,1999
}

\section{OCT 141999}

NATURAL KL - UURCE DAMAGE PECGRAM

Mr. Robert Collins, Supervisory

Natural Resource Damage Program

Old Livestock Building

1310 East Lockey Avenue

P.O. Box 201425

Helena, MT 59620-1425

Dear Mr. Collins:

(A) I am grateful and commend you for the lates araf or the Upper Claik' Fork Rive Bastr Restoraton PIan

Procedure and Criteria. It is an improvement over previous drafts. I still have concerns.

I am a native of Butte and serve on several boards concerned with the future of our community and the well being of our citizens. This, after all, is what the entire Restoration Plan should be about...the well being and health of the people most profoundly affected by mining and its byproducts through the years.

However, the politics of the process causes great concem that the purpose will be lost.

Although law may allow expenditure of the funds outside of the Upper Clark Fork River Basin, logic and policy should prevail and dictate that funds be spent in the Basin. The point is, no other community has suffered the consequences of early mining resource damage like Butte/Silver Bow and Anaconda. Our scars are deep. Entire neighborhoods were wiped out, neighborhoods rich in cultural, ethnic and historical value. Churches, schools and homes were systematically eliminated as were lawns, trees, and all surrounding landscape features. No other community suffered these kinds of loss due to past mining practices. Mountains of slag and waste material were formed in place of open spaces, native grasses and erosion barriers provided by Mother Nature. No other community bears this sort of burden. Mountains were also removed and along with them, wildlife habitat, trees and a beloved recreational area. No other community has been so profoundly burdened due to past unparalleled mining activity.

(C) I don't understand how restoration. rehabilitation. replacement and acquisition are being defined The
language should be tighter. The one prevailing criteria should be the logical decision to spend the

In addition, the organizational structure seems to be inefficient. The Advisory Council and the Trustee Restoration Council are comprised of virtually the same membership. To assure continuity and efficiency these two groups could be combined into one Upper Clark Fork River Basin Restoration and Education Advisory Council. The Attomey General could continue as an advisor and five more positions should be added for members of the public living in the impacted areas.

There needs to be a limit on money spent for administration above and bevond what is already allocated. Language must be inserted calling for annual expense reports. The litigation arm NRD staff should be separated from the restoration arm of this same staff. The process, planning and general activities of restoration is distinct from the litigation. Also, the administration and management of the restoration work should be located in the Basin where the projects will be executed.

I submit these suggestions and comments to you because I have realized you have been listening as evidenced by improvements that have been made. Thank you for your consideration.

Very Truly Yours,

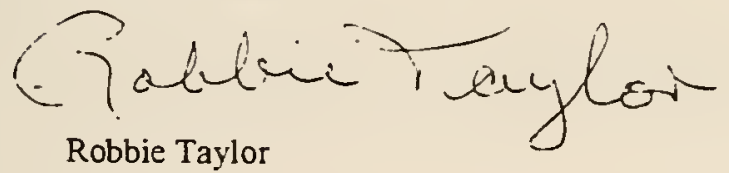

Robbie Taylor 



\section{PROJECT GREEN OF MONTANA, INC. 305 WEST MERCURY

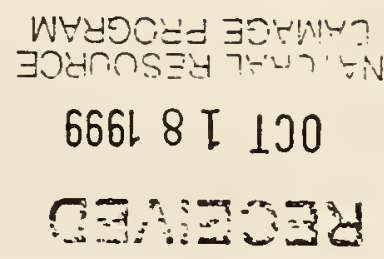

October 14,1999

Natural Resource Damage Program Public Comments

Natural Resource Damage Program

Department of Justice

Capital Station

Helena, MT 59620

Re: Public Comment on "Draft Upper Clark Fork River Basin Restoration Plan Procedures and Criteria"

Project Green of Montana, Inc. is a private, non-profit corporation which over the last 4-1/2 years has focused on "greening" projects in the Butte-Anaconda area, specifically for the area involved in Superfund remediation and Natural Resource Damage (NRD) deliberations. As a broad-based community action group, our initial efforts focused on a Greenway along Silver Bow Creek as a proper "end land use" for that corridor - relating to both remediation and restoration.

We have helped mobilize community support for many potential restoration projects. Our efforts have involved over 1000 people in public meetings, workshops, charettes, and hearings. It is on behalf of our Board of Directors and those who have worked actively with Project Green that I write this letter.

We have been concerned about finding ways that insure that NRD lawsuit proceeds are most beneficially expended in the damage area. It is in that light that we send these formal public comments on the "Draft Upper Clark Fork River Basin (UCFRB) Restoration Plan Procedures and Criteria" that was released on September 10, 1999.

First, we wish to associate ourselves with the positions taken by the local government of Butte-Silver Bow and the UCFRB Advisory Council.

More specifically, we urge changes in the draft to reflect the following: 
1. The $\$ 118$ plus interest must be spent exclusively in the UCFR Basin (the damage corridor) and the NRD program should not even consider applications for restoration projects outside the damage corridor. Based upon the state's natural resource damage claim before the Federal Court

(B) and given the recognized widespread injury to natural resources in the UCFRB, we believe that there are more restoration, rehabilitation, replacement and/or acquisition actions required in the UCFRB damage area than could ever be accomplished with the limited monies received in the NRD settlement. Because of that, there is no need to look towards doing any restoration projects outside of the UCFRB itself, and the NRD program should not even consider proposals for any such projects.

\section{The NRD restoration function should be separated from the NRD} litigation function. The legal staff at NRD has shown its expertise at

(C) lawsuits. And they need to continue with that. However, cleanup and restoration are a totally different function and should be separated from future litigation considerations. Those who are expert in remediation and restoration need to approach their important task unencumbered by the constraints of a focus on future legal actions.

3. The NRD Restoration Office should be located in the UCFR Basin, in

(D) either Butte Silver Bow or Anaconda Deer Lodge, and close to the restoration and the affected people.

4. Local people should be elevated to the decision-making level. The NRD "Policy Committee" for advising the Governor on future lawsuits (E) should be continued for that purpose, and that purpose only. But the proposed NRD "Trustee Council" should be dropped and the current NRD "Advisory Committee" (mostly local people) should become the Trustee Council, augmented by members from the state level.

We urge you to adopt these changes in your final plan.

Sincerely yours,

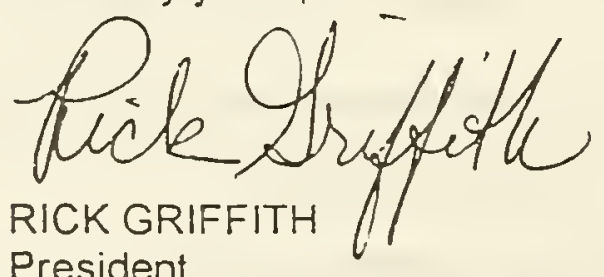

Project Green of Montana, Inc. 
Page 3 of 3

Cc: Project Green of Montana, Inc. Board of Directors UCFRB Advisory Council Members

Greenway Management Authority Board Members Butte-Silver Bow Council of Commissioners

Butte-Silver Bow Legislative Delegation

Governor Marc Racicot

Lt. Governor Judy Martz

Attorney General Joe Mazurek

Secretary of State Mike Cooney

State Auditor Mark O'Keefe 



\section{Granite Mountain Bank}

September 24, 1999

RECEIVED

SEP 271999

NATUKAL TESUURCE

DAMAGE PROGRAM

Rob Collins

Natural Resource Damage Program

Office of the Attorney General

Justice Building

Capital Complex

Helena, MT 59601

Dear Mr. Collins,

The following are my concerns about the Upper Clark Fork River Basin Restoration Plan Procedures and Criteria:

1. The draft language does not specify that all of projects be located in the basin.

(A) Unfortunately, this omission could be interpreted to allow for projects that may not benefit the impacted area.

2. The NRD Restoration Office should be located in Butte. The Clark Fork Basin is where the damaged resources are, it is where the people affected most directly by the damage live and where future projects will be located.

3. Finally, the Natural Resource Damage Program Policy Committee should be expanded

(C) Lodge and Drummond. The preliminary decisions on restoration projects are critical. To insure local support and maximum benefit, the people of the area deserve to have their representatives involved in that process in the beginning.

Sincerely,

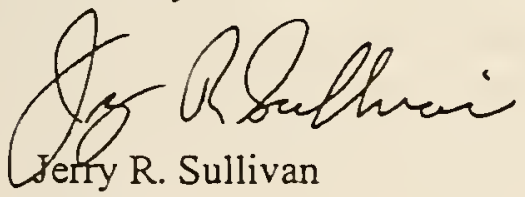

President 



\title{
St. James Community Hospital
}

\author{
WHYSOYd $\Xi 5 \forall W \forall O$

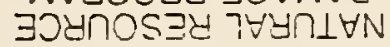 \\ $666 ! 8$ T 130
}

Oct. 14,1999

\section{QEA 30 정}

Natural Resource Damage Program Public Comments

Natural Resource Damage Program

Department of Justice

Capital Station

Helena, MT 59620

To whom it may concern:

Please add the voice of St. James Community Hospital in Butte, Mont., to the others commenting on the Draft Upper Clark Fork River Basin Restoration Plan Procedures and Criteria to the Natural Resource Damage program.

We at St. James ask that the draft restoration plan be revised to ensure that all settlement monies are spent where the natural resources damages occurred - the Upper Clark Fork River Basin damage corridor - without exceptions.

We also believe that communities in the Upper Clark Fork River Basin should have a primary role in decisions about how the settlement monies are spent. Specifically, we ask that the governor's advisory council, the Upper Clark Fork River Remediation and Restoration Education Advisory Council, comprised of river basin residents, be given a leadership role in the process. We also believe the Advisory Council should be merged with the proposed Trustee Council to ensure local involvement at the decision-making level.

We also ask that the office for the administration and management of restoration work be separated

(C) from the litigation function. Its location therefore should be placed in the Upper Clark Fork River Basin.

Thank you for your time and consideration.

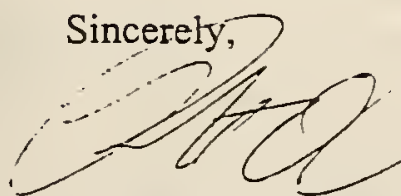

Robert D. Rodgers

Senior Executive Officer

St. James Community Hospital
-Lexter\#25

11

P.O. Box 3300

400 Sorth Clark Street

Butte, Montana 59702

(406) $723-2500$ 

October 7,1999

Mr. Rob Collins

Natural Resource Damage Program

Office of the Attorney General

Justice Building

Capital Complex

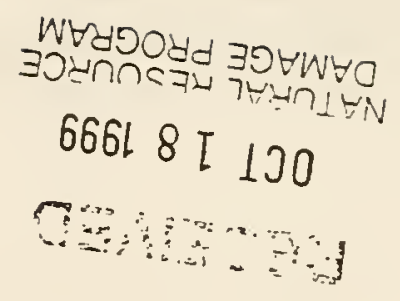

Helena, MT 59601

Dear Mr. Collins,

I am writing you as per your request for public comment on the Draft Upper Clark Fork River Basin Restoration Plan Procedures and Criteria. I would ask that my remarks be taken into consideration before the publication of the formal document.

Being born and raised in Butte, I grew up in a mining environment. The scars left behind by the previous century of mining effected our daily lives. Many people who lived in other towns in and outside of Montana would comment about how ugly the environment was around Butte and Anaconda. We never envisioned the possibility of restoring and A reclaiming the area. Today, our world is changing due in part to the settlement of the Natural Resource Damage Lawsuit. The thoughts of tuming former mining sites and polluted streams into useful natural resources is exciting for those of us raised in the area. Although the settlement amount was quite large, we all know the cost of repairing all areas in the basin to near pre-mining conditions far exceeds that sum. Therefore, I feel it is imperative all the settlement dollars be focused on restoration work within the basin.

As a businessperson working in the private sector, the efficiency by which we perform our work is very important. The location of ones project headquarter in relationship to the job site can spell the difference between performing a good job within budget and not. I am sure the contractors selected to do the actual physical work will have project offices located near the work site. Therefore, to insure proper project supervision, good communication and responsible fiscal oversight, the NRD Program office should also be located within the basin close to the work site.

Another area I would like to comment on, is the separation of the on-going NRD litigation efforts from the administration of the restoration program. It is plain to see the resources needed to be successful in these areas are distinct and unique from one another. Once a settlement is litigated, it is the responsibility of the restoration administration to (C) carry out the work. Combining or commingling personnel between these two areas would prove to be detrimental to the overall project. In addition, the funding for the litigation is already distinct from the funding for the restoration, requiring a payback for litigation costs from the proceeds of future judgements and settlements. Therefore, keeping separate and distinct funding for these two areas will show proper fiscal responsibility on the part of the project administrator. 
I appreciate the opportunity to comment on the Draft Upper Clark Fork River Restoration Plan Procedures and Criteria. I would hope my observations, along with those of others you will receive, will be taken into consideration as you finalize your document. I look forward to working with you in the future.

Sincerely,

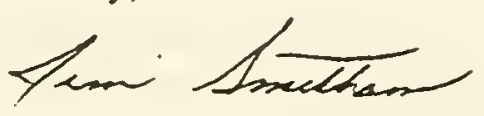

Jim Smitham

15 Redwood Dr.

Butte, MT 59701

cc: Attomey General Joe Mazurek 
BRIAN HOLLAND

$1600 \mathrm{~W}$. Steel

Butte, Montana 59701

(406) 723-9335
OCT 181999

NATURAL RESUUURE DAMAGE PROGRAM

October 15, 1999

Mr. Robert Collins, Supervisor

Natural Resource Damage Program

Old Livestock Building

1310 East Lockey Avenue

P.O. Box 201425

Helena, MT 59620-1425

Re: Comments on the Draft Upper Clark Fork River Basin Restoration Plan Procedures and Criteria

Dear Mr. Collins:

I am writing to submit some personal comments on the Draft Upper Clark Fork River Basin Restoration Plan Procedures and Criteria (Plan). I am on the Management Board of the Greenway Service District which is submitting separate comments (which obviously 1 agree with). I've also had a chance to read the comments submitted by the Butte-Silver Bow government and I agree with its comments as well.

In that regard, I would emphasize that the issue of whether to structure the criteria so that all restoration funds are spent in the Basin, with no "exception" language, is a basic policy decision for the Governor, as trustee, to make. While the concept of "exceptions" could arguably be beneficial for certain specific projects, the potential for abuse outweighs any such benefit. Given the magnitude of the damage in the Basin, and the fixed amount of dollars in the restoration fund, establishing criteria that the funds may only be used in the Basin is a better policy decision. Put another way, while such a policy may result in a worthwhile "exception" project wat being funded, there will be more than enough worthwhile projects in the Basin to utilize the available funds, and the State will avoid all the potential problems that could arise if the funds are made available to "exception" projects.

Also, I would reiterate the comment from the Greenway Service District that the Plan should add criteria that the comprehensive restoration plan factor into account which claims were released as part of the settlement. In this regard, the Plan should clarify at the outset that the geographic area to which the Plan applies will correspond to the geographic area associated with the released claims. Many people I have talked to think the Plan only applies to the area in the immediate vicinity of the waterway from Silver Bow Creek to Milltown Dam, but the geographic area corresponding to the released claims is much greater than that. A good map showing that geographic area would be a nice addition to the Plan. 
In addition to the above comments, there are a few issues which are not directly addressed in the Plan that I believe should be. Two such issues are interrelated - one is how the fund will be managed by the State Board of Investments, and the other is whether the principal and the interest on the fund will be made avallable ror projects, or just interest as some have advocated. Who will establish the criteria to guide the Board of Investments with respect to managing the fund (i.e., how much latitude in terms of being conservative or aggressive in investing the cash in the fund)? Is that something the public will have any input on? Obviously the Board's investment decisions will determine how much interest is earned on the fund, which relates to the second issue regarding whether principal and interest, or only interest, will be available. What amount of dollars is ultimately made available for projects is as important as the criteria for funding projects, so the Plan's silence on that issue is puzzling to me.

Last, but not least, l'd like to comment on the basic structure described by the Plan for administration of the program. The Plan does not indicate if the involved State officials (with the Governor as the ultimate policy maker) have thought about whether the fundamental administrative structure for the restoration program should be revisited. The current structure developed over time in a litigation context as the litigation proceeded, and was not set up to administer approximately $\$ 130$ million for restoration projects. Since there will be ongoing litigation for the outstanding claims, obviously the NRD litigation program in the Attorney General's Office should continue as currently structured. But does it make sense to have the NRD restoration program attached to the Attorney's General's Office? Should it be attached to some other State department (like DEQ since $D E Q$ is overseeing the remediation program) or possibly to the actual group that will be making the final decisions to the Governor? (In this regard I agree with comments submitted by others that that group should be a consolidated. Advisory Council/Trustee Council.) Shouldn't it be located in the Basin where the remediation and restoration projects are being done? One could even ask the if the Governor should remain trustee just because then Governor Stephens made that decision many years ago, or should the Governor delegate his trustee status to an independent agency/entity to avoid the political aspects potentially associated with the fund. In any event I would hope that the State carefully considers how the restoration program should be structured, and it doesn't make sense to me to simply overlay a structure that developed from a litigation context on a totally different project just because that's what in place at the present time.

Thank you for you hard work on this project, and I hope you consider my comments as you and others work to finalize the Plan.

$$
\begin{aligned}
& \text { Sincerely, } \\
& \text { Brein follond }
\end{aligned}
$$


$10 / 4 / 99$

Mr. Robert Collins, Supervisor

Natural Resource Damage Program

Old Livestock Building

1310 East Lockey Avenue

PO Box 201425

Helena, MT 59620-1425

Dear Mr. Collins:

As a lifelong citizen of Deer Lodge County, I would like to make comments on the draft Upper Clark Fork River Basin Restoration Plan prepared by you and released on September 10, 1999.

I have been a member of several councils and boards appointed by the Governor. I understand how hard you work and how you need to be responsive to the public. I know the commitment it requires for a member of the public to be part of a board and I know a citizen board can be successful while working with staff and department heads.

I feel that conflict exists in the proposed plans. There are too many

A conflicting Advisory Boards (Policy Council, Advisory Council, DOI, Tribal Input, Governor's Chief of Staff, Attorney General). All of these interests should be combined to form a cohesive voice in advising the Governor.

We need to get the work started. We need to start restoring the

(B) Clark Fork Basin. We need to keep the people involved. We need to spend the money in the basin. It is time to go past the lawsuit, and get down to work.

Keep the procedure simple - avoid conflicting messages. Do not set up conflict. Get the job done.

Sincerely,

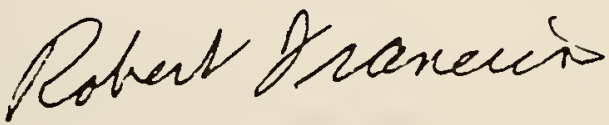

Robert Francisco 

Natural Resource Damage Program P.O. Box 201425

Helena, MT. 59620-1425
RECEIYED

OCT 071999

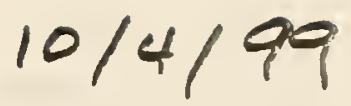

NATUNA AL WE SURCE
DAMAGE OROGRAM

DeaI NRDP Team,

Here are some comments on the NRDP Draft Restoration plan.

The introduction explains where things stand and how we got there, and says the state's claims are based on careful analysis of past damages and of alternatives for restoration. I don't see how compensable damages for CFROU and Milltown can be included since the RI/FS and ROD have not been made. Along the same lines, we don't know what remedy will be orderd by EPA for the CFROU, so we don't know the cost of actions that may be needed for restoration in this unit. If there is a rationale for this it would be helpful to state it.

On page 3 remedial response action is defined as "achieving

(B) a permanent solutuion" but $p .16$ states that the SBC remedy may result in significant residual injury. This cannot be a remedy action as defined.

On pages 5 and 23 there is no mention of the Milltown water supply replacement. Even though this action preceded the NRD

(C) lawsuit, it is an integral part of the superfund picture, and the uncertainty of the arsenic plume and potential affect on groundwater should remain as part of the state's concerns.

Chapter 3 and Fig. 2 in particular describe the structure of the process. The Governor, the Policy Committee, the Restoration Council, and the NRDP team all represent the state. The Advisory

(D) Council which is the group representing the public in fact has only a few members not affiliated with some level of government, and according to Fig. 2 appears to have a role in commenting only on early stages of draft plans. It seems like there is 
(D) Iittle real chance for the general public to be involved other than to comment on decisons already made.

Along these lines, Trout Unlimited has prepared a comprehensive document on how it envisions restoration activities should be

(E) aimed, and no doubt other groups will also express their wishes. The Advisory Council has drafted proposed criteria for projects, and other groups have proposed some specific projects.

Related to this is the time Iine proposed by the plan; project proposals will be recieved beginning Jan 2000, but the Advisory Council which has been working on guidelines still has not

(F) finalized what they want. Will that committee have time to really evaluate proposals early next year and conversely will those who propose projects get a fair and informed judgement on their proposals?

Chapter 4 appears to parallel and present in greater detail the criteria proposed by the Advisory Council. On page 37, however, reference is made to recovery period; long term is not defined, whereas the Advisory Committee uses 25 years to define longterm recovery. How does state define?

On page 37, the public support criterion --what does this

(A) paragraph mean? How about a public resource such as a riverbank (within high water boundary) area that needs restoration but a private ownership that wants no action?

In Ch. 5 p.42, example of collecting contaminated groundwater and treating -this seems to me to be a remedial action. P.43

(I) the example of acquisition of land for hunting - this does not address the damage to the land as your criteria state; how about the habitat for non-game wildife; it won't benefit from hunting 
on another chunk of land. Similar concerns with access to

(I) unimpaired tributary streams; will these types of actions be used to avoid dealing with the really tough contamination situations?

Thank you for the opportunity to comment on the plan. No doubt some of the concerns I have will be resolved as the plan is finalized and we start dealing with real situations on the ground.

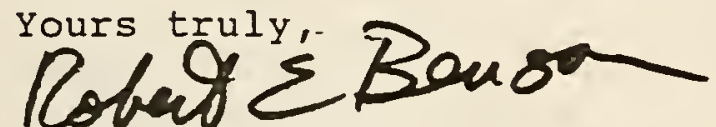

Robert E. Benson

2325 Valley Drive

Missoula Mt.

$$
59802-3147
$$



Delivered 99

$10 / 13 / 99$

Rob collins By

um FIYNN

$10-13-94$

-in flynn Chairman

Upper Clank fir h Rive Basin

Remediation 'Restoration Advisor Council

Daw Jim,

O ague with you and the other Council member on the importance of locating the

(A) restoration office in the Clarke Fork River Basin; prefuabling in Anaconda. The access to this office lo very important ic on eleterly dilation, who daw first hand the damage to on calla.

Personally $Q$ beketre acquiring the righto. To any aide all water available at this time should be first on you

(B) list of steps in restoration. All the re-vifietation this ARCO Hus already done is at risk with ont weer and any future rehabitation which will reface the lost ground cover needs to be watered.

Also ow dear trend. Bot tone certes To affruacin yous Ceryncil fa restoration

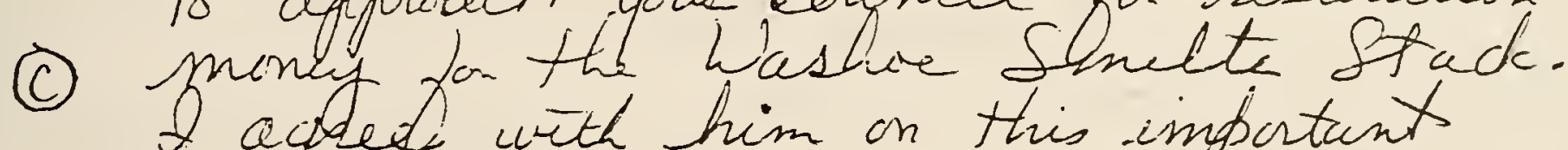
aided with him on this important Land marls' value to our area.

Thank yow

Letfer\#30 -

Margie C Dmüh 

From:

Sent:

To:

Subject:
Vicki Watson [tutrky@selway.umt.edu]

Friday, October 15, 1999 3:44 PM

rcollins@state.mt.us

comments on draft plan

Date: Oct. 15,1999

To: Rob Collins, MT NRDP

From: Vicki Watson, University of Montana

RE: Comments on Draft upper Clark Fork Restoration Plan Procedures \& Criteria

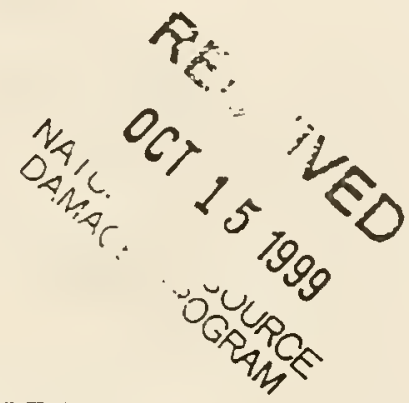

I am happy to see that the proposed procedures and criteria focus on restoration ( $\&$ not economic development) and that they take a watershed approach to restoration action in the Clark Fork. I had feared that acceptable projects would be limited to removing contamination from the mainstem. I am glad to see that projects throughout the basin will be considered if they can significantly benefit damaged resources and speed their recovery. Projects that speed the recovery of the damaged fishery can include restoration of flows and riparian areas (regardless of the cause of degradation)on the mainstem and tributaries, and $I$ am relieved to see these are considered appropriate.

However, I feel there is a need for a more coordinated approach to selecting projects. The procedures suggest that each year, each project will be evaluated largely in isolation. We need to insure that projects selected will not work at cross purposes and that projects that will have multiple benefits for overall river health should get high priority. This requires a well coordinated plan \& review procedures based on our best understanding of river ecosystem science. We also need to have an overall monitoring plan to evaluate the success of efforts, not a fragmented project-by-project approach to monitoring.

I realize some RODs will not be completed for a few years yet, and the damage suits on some areas are yet to be settled. One could argue that a comprehensive planning process should wait until these are completed. However, I think we can begin now the process of defining the goals of local citizens \& identifying opportunities, as well as considering the potential impacts of altemative types of projects. This will speed the planning process once RODs and damage suits are completed.

If comprehensive planning does wait until after RODs and damage suits are done, we should insure that only interest generated by the settlement is spent on projects until then. Larger projects (that draw from the principal) should await that comprehensive approach. And once RODs \& damage suits are done, some of the settlement funds should be used to develop a comprehensive plan involving local groups and science professionals with long term experience with the river.

Once a comprehensive plan is done, the following items should be added to criteria: how well a project serves to further the goals of the comprehensive plan; how well it works with other projects to achieve these goals.

Thanks for this opportunity to comment.

Vicki Watson, Professor, Environmental Studies University of Montana, Missoula, MT, 59812 USA 406-243-5153 fax 406-243-6090 email txtrky@selway.umt.edu 

19/15/1995 $10: 50 \quad 4605493926 \quad$ ROOKIN RUDY'S $\quad$ PAGE 01

FAR 406 e $444-0236$

TO: STRTE OF MONTANA

NATVRA REOURCE DAMAGE PROGBAM

FROM: BEMERIY DUPRRE

PO BOK 8646

MISSOUA, MT 59807

PREASE EXCUSE THE INFORMAL DELVERT OF MY COMMENT ON THE UPPER CURK FORK RIVER BSEN RESTORATION PLAN DRAET BELOW.

LWOUR UKE THE PLAN TO MENTON MORE SPELIFICALLT CONSPRAATON ENSOMENTS. "ACQUIRING AN INDEREST IN

(A) LAND" is MONTIONED, ASNEECONSERVATION EASEMEUTS, BUT ID UKE TO SEE THAT TOOL USED IN THE PLAN'S IMTLEM ONTATION.

THANK YOU FOR ACKNOULEDGING THIS SUBMISSION. 1 APOOGIZE FOR IHE LAST-MINVTE DELIVER!!

Po loprec

Letter\#32- 

Ole Ueland

R.R.\#3

Butte, MT. 59701

Phone: (406) 782-6190

September 29,1999

Mike McLane, DNRC

48 North Last Chance Gulch

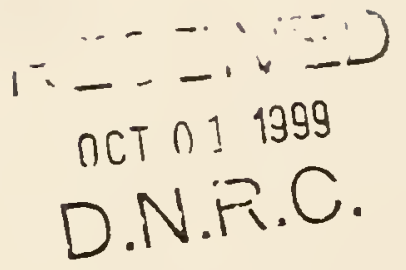

P.O. Box 201601

Helena, MT 59620-1601

Re: As per Gerald Mueller memorandum comments on report entitled "Draft Upper Clark Fork River Basin Procedures and Criteria (dated September 10, 1999)" prepared by the State's Natural Resource Damage Program (NRDP).

This report does explain the situation a little better than the March 1994 report, and does offer a start up procedure somewhat confusing and leaves many questions to be asked.

In as much as Soil and Water and related Natural Resources is the basic natural resource which serves the uses and activities of mankind, and inasmuch as the damages to Soil and Water and related natural Resources is the issue in the lawsuit of the State of Montana vs. Arco together with economic and environmental impacts.

Attached are comments I have previously drafted as a one-time land owner, for submission to the Advisory Council and the Governor, and suggesting Conservation Districts and now the Upper Clark Fork Steering Committee do the same. Hopefully these comments will be worthy of consideration and I guess I could write pages on the subject, pro and con.

The Natural resources Damage Program encourages public input! Certainly citizens, land owners, land occupiers and government agencies, need to look at their responsibilities and each other's responsibilities, political or otherwise. Is collaboration the way?

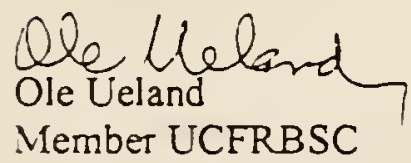



Ole Ueland

Silver Bow, MT 59750

Phone: (406) 782-6190

March 13, 1999

Deer Lodge Valley Conservation District

Board of Supervisors

Deer Lodge, MT

Subject: $\quad$ Request for DLVCD consideration on proposal to the Upper Clark Fork River Basin Restoration Plan - State of Montana Natural Resource Damage Program

Dear Supervisors:

A federal law allows states to act as trustees for natural resources to recover monetary damage for injuries caused by releases of hazardous substances. A proposed settlement with ARCO and remediation and restoration plan is partially agreed to subject to approval by EPA, the Governor and the Court. Governor Racicot has created an Advisory Council whose primary purpose is to promote public understanding of State's effort to remediate and restore sites in the Upper Clark Fork River Basin. The tenmember council has representation from business, conservation district, local government, an engineer, the public, recreationists, local planner, non-profit organization and Mary Seccombe of the MHCD is our Conservation District representative. The Council may advise the Governor on issues involving the remediation and restoration plan prepared by the State of Montana as provided by law.

As a rancher, in the Clark Fork River Basin I am concerned that agricultural lands and up lands have been overlooked in the remediation and restoration process.

Please review my Draft letter to the Governor's Advisory Council requesting greater awareness of smelter damaged grazing and agricultural uplands and my proposal to develop a trust fund for a cost-share conservation program, administered by a combination of local governments to satisfy state and federal laws, using whatever funds ARCO may provide to replace or supplement government funds.

It may be better if you supervisors submit this or similar letter or to offer your support, or to ignore this issue all together.

Sincerely,

Ole Ueland 



\title{
$\underline{\text { Draft }}$
}

To:

\author{
Members of \\ Upper Clark Fork River Basin \\ Remediation and Restoration \\ Advisory Committee
}

From: $\quad$ Ole Ueland

Silver Bow, Montana

Rancher

Subject: $\quad$ State of Montana vs. Atlantic Richfield Company (ARCO) Natural Resource Damage Program

My congratulations to each of you for accepting appointment by Governor Racicot to his Remediation and Restoration Advisory Council. It is a challenge you have to secure public opinion amidst much controversy, biases, etc. of various governmental agencies, environmental groups, small and big businesses, industry, commercial, mining, and agricultural enterprises, and the responsibilities of labor and capital.

My concern is for agriculture, soil and water conservation, and related natural resource conservation and development.

I have been involved in production agriculture all my life together with my family and as successors to my wife's family agriculture and mining operations going back to the $1880^{\prime} \mathrm{s}$ in Silver Bow County, and with more recently having purchased some farming and ranching property formerly acquired by the Anaconda Copper Mining Company from owners of several farms and ranches in Deer Lodge County, together with numerous water rights. These lands in Silver Bow and Deer Lodge Counties together with those of several neighbors are adjacent to or within Super Fund Sites and ARCO lands.

I also have had considerable experience in Soil and Water Conservation matters as an officer at local and state levels. Of course, I am only human and don't know it all.

ARCO has been a good neighbor in many ways and I commend them for their participation and cooperation in adversarial matters and perhaps unfair disadvantages. They are big business and have some advantages and disadvantages in defending themselves as a Principal Responsible Party (PRP).

I feel obligated to give you some of my observations and suggestions:

1) I am not happy with the inattention or apparent neglect of the impact on the agriculture environment directly and indirectly.

2) God created this world, these natural resources, and created man and woman to be good stewards. Reflecting back we have all sinned at times 
inadvertently in our stewardship. Looking and planning ahead we need to set priorities to restore, renew, remediate for wise use, highest and best use among many competitive uses.

3) Of highest priority, those of us in food and fiber production agriculture remind you that man and all living creatures have dependence on clean water, productive soil, suniight (energy), clean air, every day for the food we eat, and give thanks for. Shouldn't agriculture be our first priority in providing, in improving, and providing a proper habitat to live, work, and play for all living creatures, mankind, and especially for an ever growing population, and for many generations to come.

4) Soil and Water Conservation and Environmental Protection are the issue answer.

How are we going to provide for the human race 1000 years from now? Or even 100 years? Isn't soil conservation the answer? Perhaps you should advise Governor Racicot to instruct all agencies which he is the boss of to collaborate, communicate, coordinate, and cooperate in Soil and Water Conservation which is an inherent responsibility of all agencies, all mankind now and for the future, no matter what the land use.

Or maybe the Attorney General should research and make certain all laws pertaining to Natural Resources Soil and Water Conservation are being followed or where there are conflicts so that the legislature, the Governor, the Courts can be better advised.

5) Quoting from the Governor's Executive Order: WHEREAS, CERCLA requires that natural damage awards be used only to restore, replace, or "acquire the equivalent" (quote marks are mine) of the injured natural resource that are subject to the litigation 42 USC. 9607 ( $f$ (1). My suggestion is a trade off to the loss of the ag land or other lands that can't affordably be restored (Opportunity Ponds, etc.) that a good share of that assessed damage restoration be tumed over to the Conservation Districts and the County Government in the Upper Clark Fork Basin inasmuch as they have Natural Resource decision making responsibilities at the local level and are obligated to carry out state and federal (law) directives.

As an example of immediate public and private concern in which Conservation Districts, County Government, and County Weed Districts have responsibilities is Noxious Weed Control. Noxious Weeds are currently devaluing land for which food and fiber production is dependent and related beneficial uses. Farmers and Ranchers can't afford totally to eradicate, so a cost-sharing mechanism should be set up with these Damage Control 
Restoration funds. We must remember that soil and water conservation practices heip protect the tax base.

б) There are many other standards and specifications (best management practices) enumerated in the Natural Resource Conservation Service, Extension Service, research Service, Department of Environmental Quality, Agriculture, DNRC, Fish Wildlife and Parks, etc. manuals that rate high in priority that could be cost shared with farmers and ranchers, and other land occupiers, using these funds on a collaborative basis, especially stream bank and upland practices.

One program I am especially fond of is how the Small Watershed and Flood Prevention Program works (PL566). This could be set up in many of our small tributary watersheds to main stem streams to conserve and provide water for many benefits including Total Maximum Daily Load stream dewatering mitigation. There are many potential sites in Silver Bow County such as Browns Gulch, Little Blacktail, Sand Creek, and like sites in Deer Lodge, Powell, and Granite Counties. These dams and water spreading systems certainly can help the MDL goals, water quality goals by diluting some of the hazardous runoff from sites such as Opportunity Ponds or pollutants that remain in streams that are not likeiy to be totally cleaned up; together with the benefits of flood prevention, streamed protection, stream bank protection, supplemental water supply for irrigation, fishery, power generation, municipal, industrial, multiple uses, each managed according its needs. By planning and working with land occupiers, farmers, ranchers, residential, commercial, industrial, transportation, developers, recreationist, environmentalists, for soil and water conservation, water quality, on a watershed and sub watershed basis; by confining these efforts in this case basically to the Upper Clark Fork Basin above Missoula.

7) Now getting more specific as to the lawsuit of the State of Montana against Atlantic Richfield Company (ARCO); the Restoration Report Upper Clark Fork River, NPL Sites, March 1994, I would compliment the Attomey General Office for much work and analysis. (An awful lot of work must have been done to cost $\$ 15$ million!) And yet more needs to be done as we are now involved in recommendations, suggestions, or observations, and what to use the money for. Is the $\$ 100$ million proposed for restoration and remediation purposes for the basin below the Warm Springs Ponds only? OT to be investments that help the whole basin?

Apparently the State Attomey General report confined its case to ARCO properties remediation, public property, and ARCO damages to state owned property such as fish and wildlife, and hazardous wastes to health and human impacts. I am not sufficiently convinced that agricultural land loss, along with private and public benefit damage was covered or reported. Shouldn't the loss, 3200 acres of prime ag land covered by tailings that make up the 
Opportunity Ponds and similar adjacent acreage that is questionable or unaffordable to restore and its loss forever to future use for food and fiber production and or other uses and a loss of that tax base to Deer Lodge County? And several adjoining existing farms and ranches with smoke and hazardous waste damage caused by smelter operations? As a trade off to loss to these unrestorable lands it seems very logical to add value to adjacent Upper Clark Fork Basin lands by carry out of aforementioned soil and water conservation practices which in most cases also help solve damages to downstream waters.

8) The reported settlement of the State with ARCO of \$215 million apparently leaves $\$ 100$ million to which Governor Racicot is seeking counsel and advice of how to use it. The idea that the principal be invested in an interest bearing trust and the interest income of several million dollars each year be used by Conservation Districts and County Government as cost sharing for priority projects as chosen by these local government entities seems good as one option, except that inflation would have an adverse effect?

9) A list of proposed projects should be formulated and maintained and priorities given for submission to the Governor for his approval and early execution.

10) A local government entity to administer the above suggested program could be patterned after the Headwaters Resource Conservation and Development Area (HRCD) consisting of counties, cities, towns, and Conservation Districts in the Upper Clark Fork River Basin.

11) You should refer comments of other persons and mine to all local, state, and federal agencies with Natural Resource Conservation and Development responsibilities, landowners and occupiers of record, public and private, and to request their feedback.

12) Question of issue of whom gets rich? Society or individuals or both? Good Luck. You have an important task. We all should be proud of the results.

(God: give us the wisdom, the knowledge, the understanding, the fortitude, the patience, and the guidance to do thy will to be good stewards of the Natural Resources you have created.) 
Bill Janecke

October 14,1999

1811 Tammany

Anaconda, MT 59711

406-563-3980

bjanecke@mtpower.com

Rob Collins

Natural Resources Damage Program

PO Box 201425

Helena, MT 59620-1425

RE: Comments for the Draft Upper Clark River Basin Restoration...

Dear Rob:

After reviewing the Draft Upper Clark River Basin Restoration Plan Procedures and Criteria for disbursement of the Montana v. ARCO settlement monies, I have a few concerns that I would like to share with the Natural Resources Damage Program. The following are a list of my comments concerning the document. The comments are separated by chapter and pages within each chapter.

Chapter 3, page 28

Grants to non-government organizations

If a grant is awarded to a non-government organization will they be required to follow the

(A) State's procurement procedures and contracting laws? If not, what procurement and contracting procedures might be imposed? How will non-government organizations be made aware of whatever procurement and contracting procedures they are to follow?

Chapter 3, page 29

Qualifications

Will each applicant for NRD funds be required to state their qualifications as a condition for consideration for NRD funds? If not, when will qualifications of applicants be sought? Will the qualifications of applicants be a matter of public record?

Chapter 3, page 29

Project development funding

Is the time frame and application process the same for project development grants (e.g.-

(C) feasibility studies, preliminary designs, cost analyses, etc.) as it is for shorter duration work? If yes, then can a continuous funding cycle be established for project development grants that fall below a certain dollar threshold amount?

Chapter 3, page 31

Public comments

(D) Can the public comment period be extended to 45 days to allow a person to gather background information prior to commenting? Can a single and/or multiple projects be 
rejected from the Restoration Work Plan without rejecting the entire plan? If no, then can the procedure be altered to allow for the rejection of individual projects within the Restoration Work Plan?

Chapter 3, page 33

Design detail

What detail will be required for the final designs submitted to NRDP, especially on the non-engineered projects? Will NRDP be required to review and return the final designs within the 30-day pre-construction period?

Chapter 3, additional comments

(E) 1. Can grant applications be submitted for multiple year grants (e.g.- $\$ 50,000 /$ year for three years)?

(G) 2. How much time does the applicant have to expend grant amounts? Will successful applicants be required to expend granted dollars within the granting year?

(H) 3. Who controls funds prior to expenditures and who retains interest from granted amounts prior to expenditure? (I) 4. How will MEPA requirements be met? Will all successtul applicants be requifed to
complete EA's or EIS's?

Chapter 4, page 38

Project area

Will drainages such as the Little Blackfoot River, Flint Creek, Rock Creek (Clinton), etc. be acceptable areas for project applications within the first two granting cycles? What is the downstream most location eligible for grants in the first two granting cycles?

Chapter 4, page 39

Matching funds

6. Can a requirement of at least a $25 \%$ cost share be required on all grant applications for matching funds? How will landowner contributions be evaluated?

Chapter 5 , page 45

Administration

(1) What will be the documentation requirements on all projects? Will quarterly progress or annual progress reports be required?

Thank you.

Sincerely,

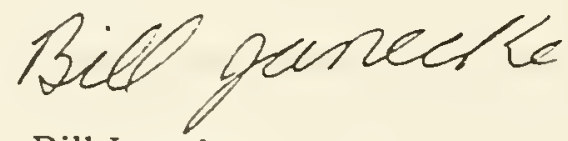

Bill Janecke 


\section{Friz vally 1408 Warren Ave Butte MT 59701}

September 8, 1999

Mr. Joe Mazurek

Montana Attorney General

215 N. Sanders

Helena MT 59620-1401
RECEI

\author{
SEP 141999
}

QTTORNEY GENERALS OFFICE

HELENA. MONTANA

Dear Joe:

Please list me as an opponent of the Upper Clark Fork River Basin Restoration Plan prepared by the Natural Resource Damage Program Also, please include this letter as part of the official record. While much of the information in the document is positive and addresses many of my concerns, several sections of the document are arbiguous and will defmiteiy lead to numerous conflicts in the future.

My main concern, which I have addressed to you on numerous occasions, is the fact that the document allows the settlement monies to be spent outside of the area where the original damages occurred. While most of the information in the Document is excellent and strongly points out that the monies should absolutely be spent in the areas where the original lawsurt requested the damage clains, it allows the monies to be spent anywhere the Governor so desires.

I would point out to you once again, $87 \%$ of the original 5765 million claim was for damages that occurred in Butte, Anaconda and on Silver Bow Creek. In addinion, over $74 \%$ of the final Restoration claim was for restoration costs excluding compensable costs in the same area. While you have always publicly stated that the monies must be spent in the damaged areas, your written documentation and your comments to Judge Harfield have been totally contrary. I find it extremely difficult to understand why you continue to publicly stare that the monies must be spent in the areas where the damages occurred, while your written statements allow the monies to be spent anywhere the Governor as Inustee so desires.

As you know, in litigation the written docurnentation always takes precedent over oral statements. In the future, it will be perfectly clear what information is contained in the written documents, but very little credence will be placed on what someone thought they would like it to say, for political purposes, in 1998.

While most of the emphasis on the Settlement now seems to be on restoration of the Clark Fork River, only $13 \%$ of the original clairn was for this area I am a strong supporter of cleanup and restoration of the Clark Fork River and most importantly the communities of Milltown, Deer Lodge and smaller comonunites along the corridor. However, the communities of Butre and Anaconda are absolutely entitied to have a major portion of the restoration money spent directly 
on restoration projects in their commuities. As I have advised you in the past, the tarpayers of Butte were forced by the EPA to franace a 540 million renovation of thei water system, or face huge monetary fines from the State of Montana and the EPA. As you know, a major portion of the lawsuit dealt directly with the destruction of the Burte Bedrock and Alluvial Aquifers, and was one of the primary purposes of the original lawsuit.

I am also adamanty opposed to creating another permanent stare bureaucracy as the document proposes. The current Narural Resource Damage Program should absolutely sumset at the completion of the current serlement negotiations or trial If the Helena bureaucracy was taken totally out of the process, we would all be berter off. It's redicuious for the EPA office and the Departrnent of Environmental Quality office dealug with this issue to remain in Helena.

(F) I am also opposed to maiking the current Upper Clark Fork Advisory Committee a so called "Feel Good Committee" for the satisfaction of the Trustee, as the document proposes. The Advisory Committee, if used properiy, could absolunely assure that the monies are properly allocated. The current proposal now alls for the creation of a super Department Hesd Committe" locafed in Helena If this Super Committee is allowed to remain in place, it will guarantee that the residents of Butte, Araconda, Deer Lodge and Milltown will have to stand in line in Helena and beg the Committee or the Legislature to receive a small pittance of the Settlement.

Joe, I'm proud to be from Butte and I am proud of the contributions made by the past residents of Butte and Araconda in the shaping of this great State and this great Nation Without their significant dedication and contributions, you and I would not be Irving in this great State, and in all probability our rative language would be Japanese or Gerwan

I'm extremely thankfil that your office and the Narural Resource Damage Program office are not in charge of the monies being used to assist the victins of the Turkey Earthquake. In all

(4) probability your office and the Natural resource Damage Program office would propose to use the monies for restoration projects in Central Park in New York City, or to create another government bureaucracy program in Washington, D.C. or in Helena

In closing, while I am discouraged that my commenis will in all probabilty not be.taken seriousiy, as has been the case with my other comments and suggestions to you and Judge Hatfield, I still feel compelled to write. I believe strongly that if you and Judge Hatfieid had bstened to the comments and suggestions of myself and other Burte and Anaconda residents, the State of Montana would now have a Settlement in which we could all be proud and a Settlement that would definitely better serve all of the residents of Montana.

Joe, I am aiso still waiting for your response to my questions mailed to you on Aprii 7,1999 and Apri 26, 1999.

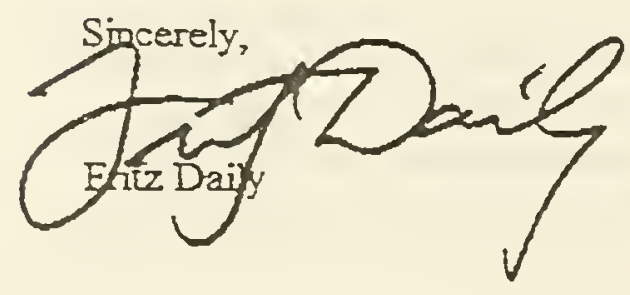


October 6, 1999
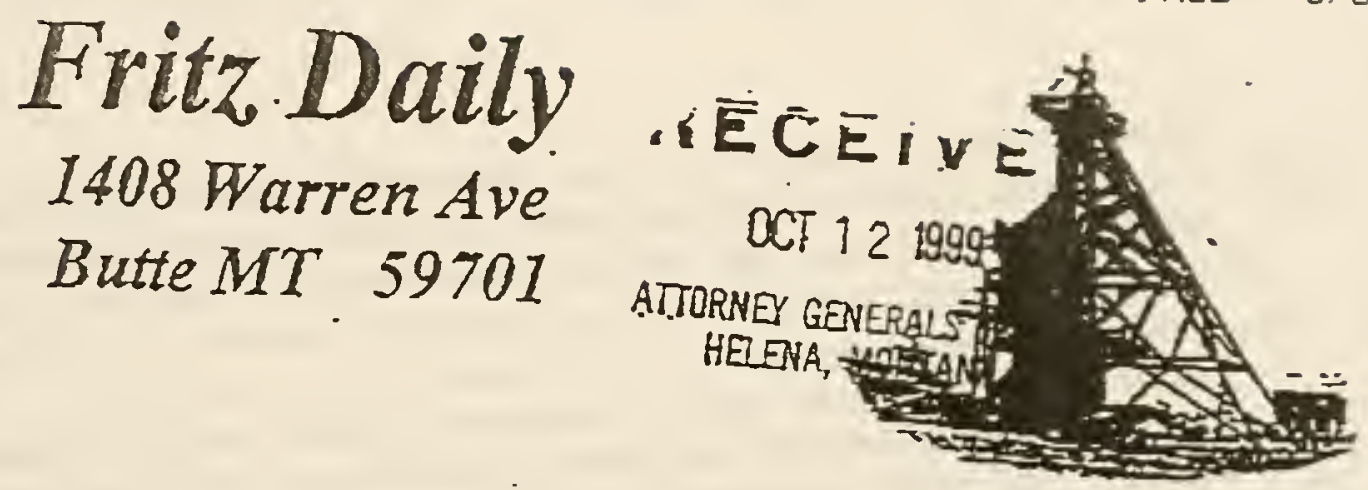

Mr. Joe Mazurej

Montana Attorney Geperai

$215 N$. Sanders

Heiene MT 59620-1401

Dear Joe:

Thanks for sending me a copy of the revised edition of the Upper Clark Fork River Basin

Restoration Plan Would you please inchude this letter stating my oppostion to the proposed pian

(A) Butte MT 59701

part of wy optical record In adirition, would you also include my September 9, 1999 letter as concerns with both documents.

While the new document is somewhat berter, it absolutely does not address my major concens. Mainty, the new document still allows the Governor to spend the money anywhere be so desires, and it scill leaves total comtrol of the funds in the hands of the burearcracy in Helena.

In Feiruary. I made a presentation to the Bunte Silver Bow Councll of Commissioners and Chief Executive Jack Lynci concenning these very issues. I strongly encouraged the local government to become actively invoived in the lawsuit to prevent these very such things from happeniog. The Council received assurances from you and from members of your staff that this wasn't necessary because Federal Law prevented the monies from being spent outside of the areas where the original damages occurred You aiso assured them that a citizen's advisory conumittee was also in place to prevent these actions from occuring. It is now very evidert, with the release of the final Sertement and with the release of the Restoration Plan, that I was absolutely correct I am bopeful that in the funtre the Council and the Chief Executive will again address this issue, and seex legal council to address the original sertement and to also address the remaining ursettled

I am also very troubled by the cinanges that bave ben made in Chapter Five I believe this section now absohurely prechudes the Butte Project Green Commitie from presenting their proposal for a new Columbia Gardens type park in Butte. I believe it also prechudes the development of any such future type proposals. This section suggests that the Sertlement is only designed to address restoration on the Clark Fork River and Sitver Bow Creck I would again advise you that $87 \%$ of the final lawsuit proposal prepared by the Natural Resource Damage Program in March of 1994 addressed restoration in Butte, Araconda andi on Silver Bow Creek.

As you know, more than a thousand Bune residents, inchuing chidren, worked hudreds of hours purting togetier the outsanaing concept known as the Bunte Gardens. Whie everyone who worked on the project knew that to totai project would probabiy not be funded, we all felt that 
(C) Project Green Corme project would at least be considered In a previous moting in Butre witin menifess of the proposal was a viabie proposi and comrmity leaders, you aiso stated torr you felt the Gardens the Project Green Conm pould you please adoress this issue to they may inform the community of your curreut feeing.

Joe as I have documented for you on numerous occasions, one of the prinary purposes for filing the original lawsurt deait with the destruction of the Bute Bedrock and Afuvial Aquiters. On April 22, 1982, when the original mine llooding began and again in September of 1994 when the Mine Flooding Record of Decision was issued, the State of Momam and the Ervirommal Protection Agency made inproper and incompetent decisions concening this isue Those decisions have now allowed these aquifers to curremity contain more than 70 billion gallons of contaminated toxic water. Utimately, besause of these decisions the Berikeley Pit alone will comain more than 54 bilfion gallons of toxic water, and the remainder of the aquifers will contain
approximately 50 builron gallons more.

What EPA and the State of Montana have allowed to happen to this community, by allowing these aquifers to flood, is unconscionaibie. It should not have been tolerated in the past and it shovid absohutefy not be allowed to comime into the furure It appears to me that we now bave a settlemem that was designed to address some of these issues, and the State is now doing everything in its power to see that very little if any of the Settlememt money is spent in our

Joe, I am sorry to be so subtle and direct in writing this letter. However, at this point I don't know how eise to do to adiress the issue. In the past, I have written several constnuctive letters to you and to Judge Farfield and my comments and suggestions have besically been ignored. Joe, I an still willing to visit with you personaily to addiress uny concerns.

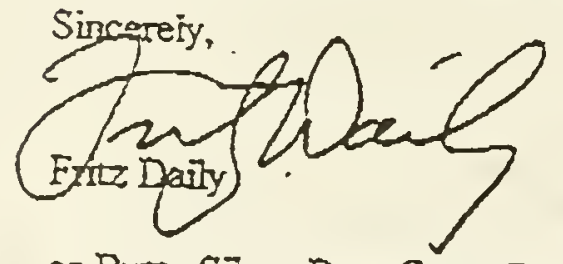

ec Butte Siver Bow Council of Commissioners

Chief Executive Jack Lyach

Project Green

Don Peopies

Butte Press

Enclosure-September 8, 1999 Lerter 
NRD Program Justice Dept Capital Station Helina, UT 59620

Thr. Collins -
$P^{2}$

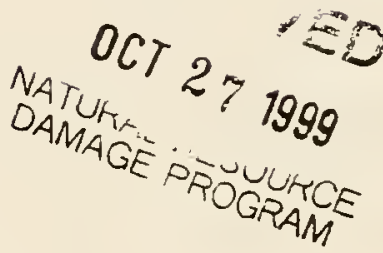

U think ALL of the Atro Settement inoneer sivould be spent in the arsas which suffered darkage from mining.

\& do not care whele the sesource oppice is based. If it's cheaper aud mone placticat to be un Helewa heal ottiel acincies, rine. Howevel, \& Do think it should be staffed be prople flom The afyected areas who know what the probtems are and not by mene buseaciats.

Und iuster, it ciet so tirak "C perpe trom Mlissoula, whese damage is ininimat, saying that Butte "just waats to ppend the 
nunsy on a park" and therefore doesn't asserve tunas. Missonea didu't lose an incrediate park to mining - Butt did. Jue Columbia Fordens cau't be rebriet but it cau and should be keplaced in Est Butt's abaudoned areas.

Sincerely 1429 W. Granite Butt, MT 59001

PAMSWIGER
PA29WESTGRANITE
BUTTE, MT59701
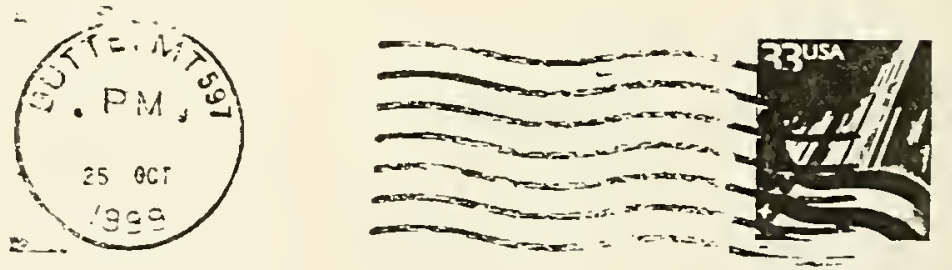

NRD Draft Plan Corments \% Rot Collins

URO Progiam

Justice DEvt.

Capital Station

HEleme, MTT 59620 
October 26, 1999

Rob Collins

Natural Resource Damage Program

Office of Attorney General

Justice Building

Capitol Complex

Helena, MT 59601

\author{
REUENEO
}

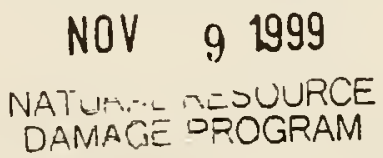

Dear Mr. Collins:

The Board of Directors of Butte's Citizens' Technical Environmental Committee has had an opportunity to review your working draft of the Upper Clark Fork Basin Restoration Plan Procedures and Criteria, and we would like to submit these comments:

The CTEC Board voted unanimously in support of limiting the spending of settlement monies to within the damaged corridor. It is the fear of the CTEC Board that if any exception is allowed in project consideration, then there will be increased pressure to shortcut solutions along the river. The decision to fund projects outside the basin would be difficult to stop if permitted, but maintaining the focus on the best possible clean-up of the river corridor will not rule out other projects when acceptable goals are met.

It may be cheaper to purchase an undamaged watershed, instead of cleaning up the area that is damaged. What the communities along the river are entitled to, however. is a clean river. A task which by all indications will not be an easy one. Using the "most, if not all..." language only, we believe, signals some folks to look for other, cost effective, projects.

Another concern of the CTEC Board was the concentration of power in the NRD office and the lack of adequate representation by citizen groups. At a minimum, we believe, it would be appropriate to include the chair of the Governor's advisory committee as a voting member of the technical committee.

The CTEC Board also supports the Advisory Committee's call for the location of a restoration office in the affected areas. We go one step further, however, and also recommend 
that the office be located in Silver Bow or Deer Lodge counties. There is a great deal of concern about the levels of administration costs that have been suggested during various clean-up discussions.

As we have indicated in the past. right or wrong, there is a great deal of public belief that bureaucracy will remain healthy, but the river will not. Placing an office in the most impacted communities will go at least part way to showing the public that clean water and not other priorities remain the primary goal.

CTEC looks forward to reviewing the final proposal, and will participate with comments at that time. But until then we wanted you to know of the considerable community imput we have received regarding the above issues.

Thank you for your consideration of these concerns.

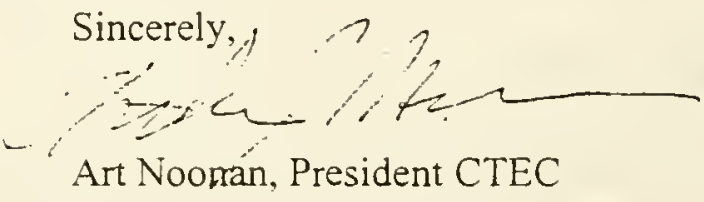



